\title{
WestVirginiaUniversity
}

THE RESEARCH REPOSITORY @ WVU

Graduate Theses, Dissertations, and Problem Reports

2013

\section{The teaching legacy of Iravati M. Sudiarso}

Mario S. Santoso

West Virginia University

Follow this and additional works at: https://researchrepository.wvu.edu/etd

\section{Recommended Citation}

Santoso, Mario S., "The teaching legacy of Iravati M. Sudiarso" (2013). Graduate Theses, Dissertations, and Problem Reports. 177.

https://researchrepository.wvu.edu/etd/177

This Dissertation is protected by copyright and/or related rights. It has been brought to you by the The Research Repository @ WVU with permission from the rights-holder(s). You are free to use this Dissertation in any way that is permitted by the copyright and related rights legislation that applies to your use. For other uses you must obtain permission from the rights-holder(s) directly, unless additional rights are indicated by a Creative Commons license in the record and/ or on the work itself. This Dissertation has been accepted for inclusion in WVU Graduate Theses, Dissertations, and Problem Reports collection by an authorized administrator of The Research Repository @ WVU.

For more information, please contact researchrepository@mail.wvu.edu. 
THE TEACHING LEGACY OF IRAVATI M. SUDIARSO

Mario S. Santoso

A Doctoral Research Project Submitted to the College of Creative Arts at West Virginia University

in partial fulfillment of the requirements for the degree of

Doctor of Musical Arts in

Piano Performance

Peter Amstutz, D.M.A., Chair and Research Advisor James Miltenberger, D.M.A. William Haller, D.M.A. William Skidmore, M.M. Bruce Kang, Ph.D.

School of Music

Morgantown, West Virginia

2013

Search keywords: Iravati Sudiarso, Piano Teachers, Master Teachers, Legacy, Lineage, Johannes Nugroho, Levi Gunardi, Citra, Happy Birthday Copyright 2013 Mario Santoso 


\section{ABSTRACT \\ The Teaching Legacy of Iravati M. Sudiarso}

Mario S. Santoso

Iravati Mangunkusumo Sudiarso (born in 1937, in Surabaya) is one of Indonesia's most respected musical figures. Famous throughout Indonesia as a pianist and teacher, Sudiarso has produced successful generations of pianists for more than forty years. With her professionalism and idealism in teaching, combined with endless dedication, Sudiarso has guided many students to achieve high artistry and taste in piano playing. The author had the privilege of studying with Iravati Sudiarso from 1996 through 2000, an experience which brought personal knowledge of her teaching.

Several of Sudiarso's students have composed music dedicated to her, but no one has written a comprehensive study of her teaching legacy. In addition to describing Sudiarso's influence on piano playing throughout Indonesia, this study will analyze piano pieces written by two of her other former students in honor of Sudiarso: "Citra," by Dr. Johannes S. Nugroho; and "Happy Birthday," by Levi Gunardi. 


\title{
Dedicated to:
}

\author{
Iravati M. Sudiarso
}




\section{ACKNOWLEDGEMENTS}

I extend my gratitude to the following individuals and organizations:

Mrs. Iravati M. Sudiarso, for her teaching and for sharing her thoughtful and inspiring life stories;

My great colleagues at Universitas Pelita Harapan and other music schools, who helped me by gathering information about Sudiarso and writing testimonials regarding their remembrances of studying with her;

My major professor and research advisor, Dr. Peter Amstutz, for his patience, continuous support, and expertise throughout my doctoral study;

My DMA committee members, Dr. James Miltenberger, Dr. William Haller, Prof. William Skidmore, and Dr. Bruce Kang, for their generous support throughout my doctoral study

My wife, parents, and parents-in-law, for their care and love during these challenging years; and for their support in helping me complete this project;

Mrs. Susiana Aditjhan Wibowo, for teaching me during my eight years at Yayasan Pendidikan Musik. I would not have this music career without your guidance.

Dr. Johannes S. Nugroho and Mr. Levi Gunardi, for sharing their thoughts and guidance about their compositions written in honor of Mrs. Sudiarso;

Yayasan Pendidikan Musik Music School for giving me such a good start during my early training as a musician. 


\section{Table of Contents}

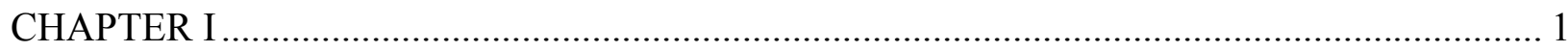

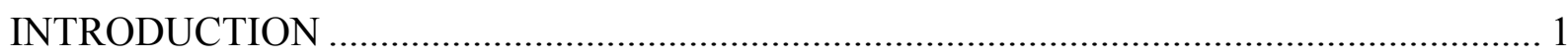

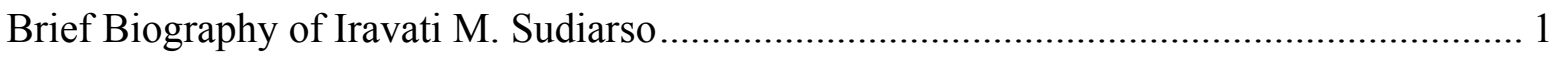

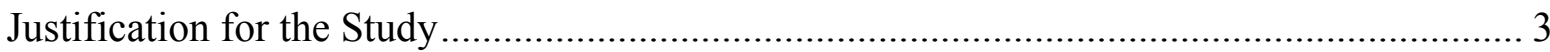

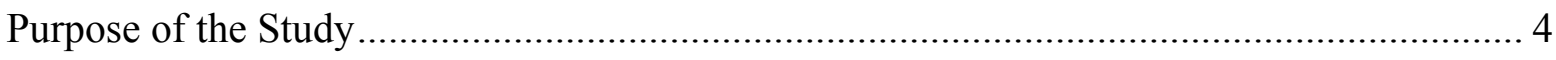

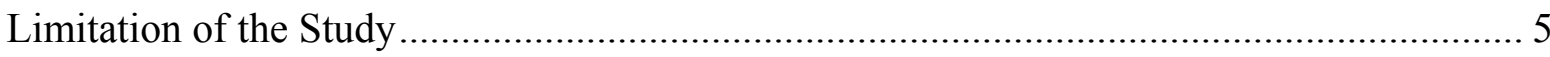

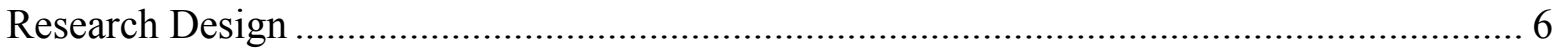

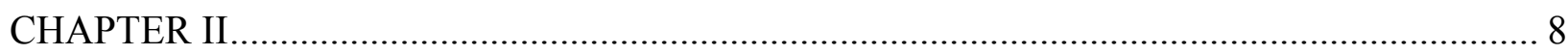

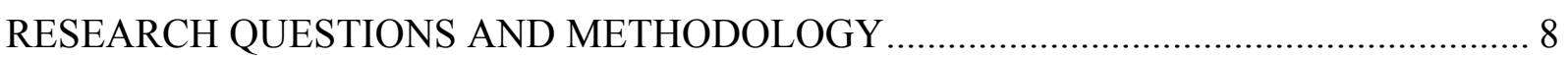

Studies with Related Methodology.............................................................................. 8

Research Procedures and Documentation ...................................................................... 12

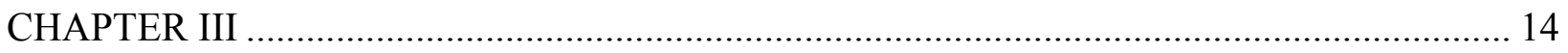

SUDIARSO'S BIOGRAPHY AND PROFESSIONAL ACTIVITIES.................................... 14

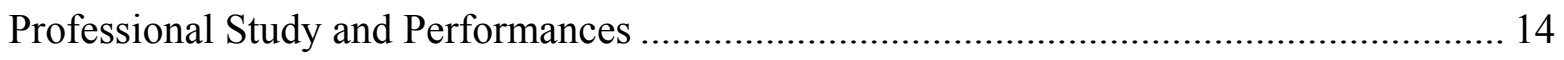

Yayasan Pendidikan Musik Music School ........................................................................... 17

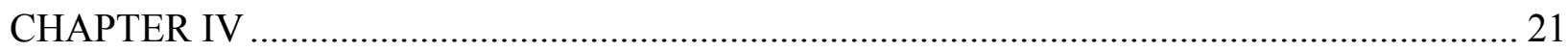

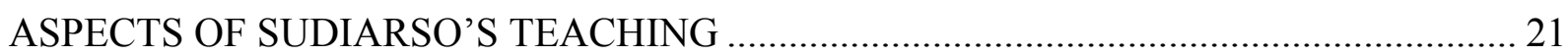

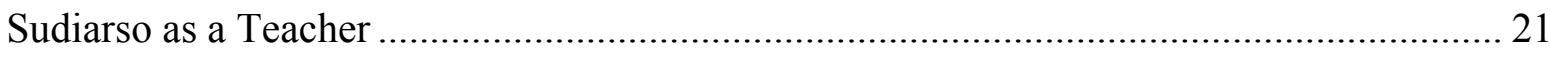

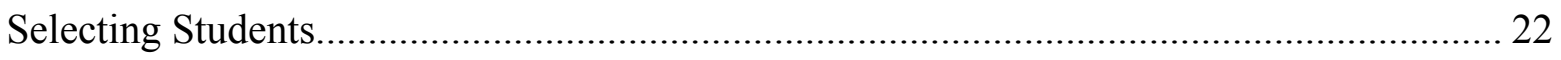

The Importance of Teaching............................................................................................ 23

The Demanding Nature of Her Lessons ......................................................................... 24

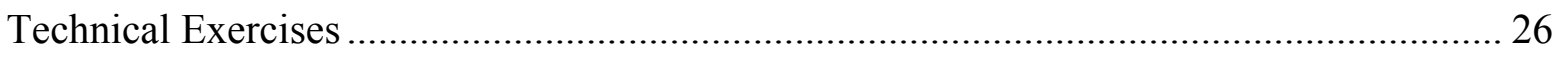

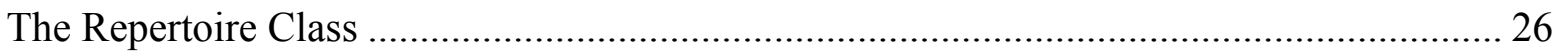

Her Thoughts Regarding the Next Generation of Musicians in Indonesia............................. 26

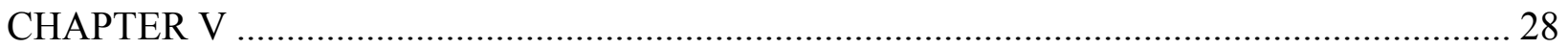

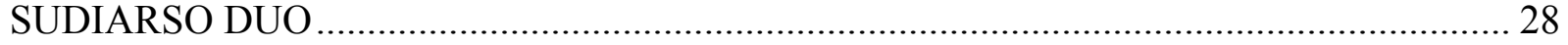




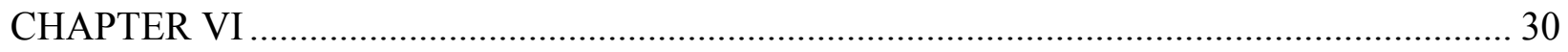

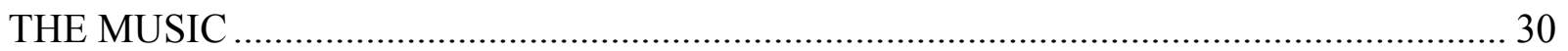

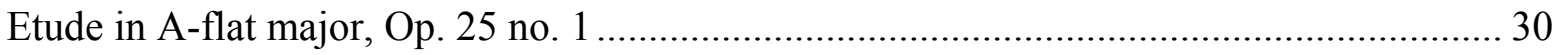

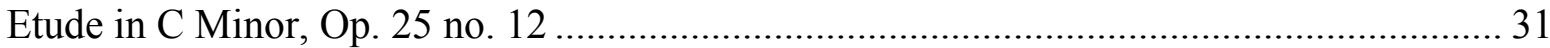

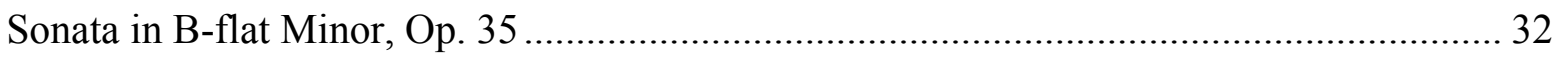

Liszt: Paganini Etude No. V ........................................................................................ 33

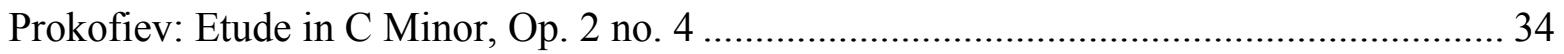

Mendelssohn: Rondo Capriccioso, Op. 14 …………………........................................ 35

Rachmaninoff: Prelude in G Minor, Op. 23 no. 5 ………………………………....... 35

Schulz-Evler Concert Arabesque on the "Blue Danube" ..................................................... 36

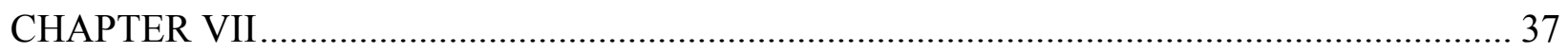

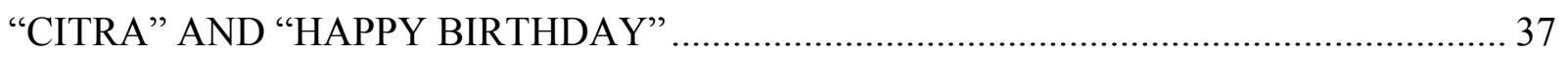

Nugroho's Citra ............................................................................................................. 39

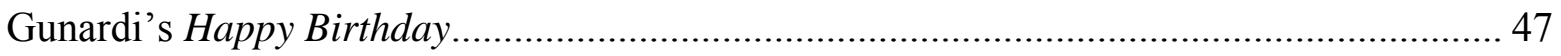

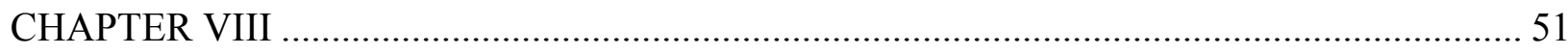

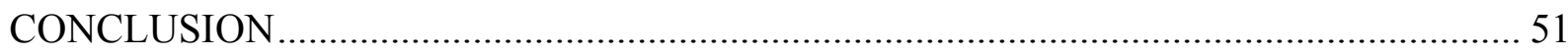

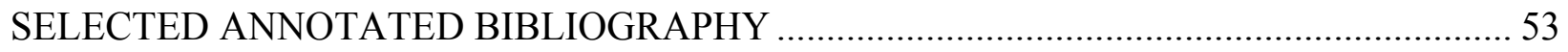

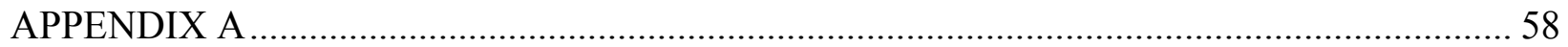

An Article in Kompas, dated 30 June, 1996. "Lebih Jauh dengan Iravati M. Sudiarso"........... 58

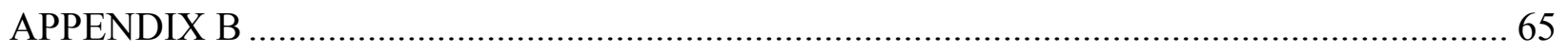

An Article in The Jakarta Post,dated 1 September, 2002. "Gifted Iravati has a heart for music"

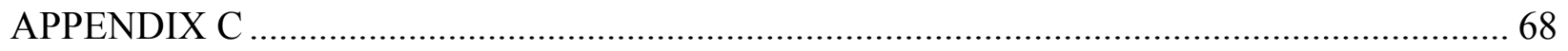

SELECTED TESTIMONIALS BY INDONESIAN MUSICIANS ………………………...... 68

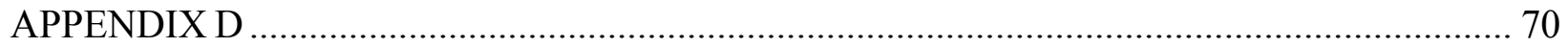

Yayasan Pendidikan Musik Music School ............................................................................. 70

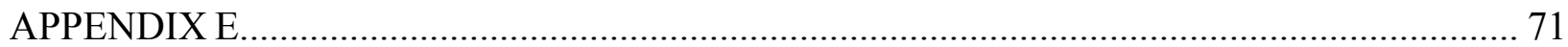

Johannes Nugroho's Citra.............................................................................................. 71 


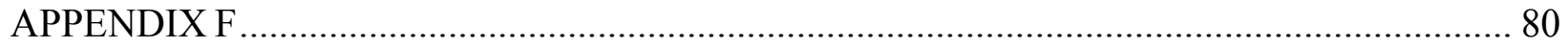

Levi Gunardi’s Happy Birthday ....................................................................................... 80 


\section{CHAPTER I}

\section{INTRODUCTION}

\section{Brief Biography of Iravati M. Sudiarso}

Both as performer and teacher, pianist Iravati Mangunkusumo Sudiarso has shaped the musical landscape of Indonesia. Her performances are always memorable and highly praised by both critics and audience; regarding her performance, Delima Simamora (a professional vocalist) stated:

Iravati Sudiarso is an important music icon in Indonesia, especially in the field of piano playing and teaching. I always admire her performances, which are consistently clear, with such energy that she keeps the audience in awe. Soul, energy, and accuracy, combined with very strong technique, can be observed in all her playing. ${ }^{1}$

Her aura as a pedagogue is so special that she has been dedicating herself to creating "persons, not machines" ${ }^{2}$ for more than forty years now. Her teaching about appreciating music in its integration with life reminds me constantly to love music with all my heart and to give it my best effort. Her teaching impact on my development as a pianist is so tremendous that I believe other colleagues will have been similarly influenced.

Sudiarso is a nationally recognized concert pianist and pedagogue in Indonesia. She has been honored as a recipient of national and international professional awards, including a Cultural Award given by the Australian Government in 1974 and a Cultural Award from the Japanese Foreign Ministry and the Japan Foundation in 1979. The International Cultural Society of Korea chose her to be an Honorary Member in 1979 for her contributions to Asian cultural

\footnotetext{
${ }^{1}$ Delima Simamora, emailed to Mario Santoso, Jakarta, Indonesia, July 9, 2013.

${ }^{2}$ My own remembrance of her teaching during my study at Yayasan Pendidikan Musik music school. Tania Budihardjo "Gifted Iravati Has a Heart for Music," Jakarta Post, http://www.thejakartapost.com/news/2002/09/01/gifted-iravati-has-a-heart-music.html (accessed April 11, 2013).
} 
achievements and she received the Franz Liszt Memorial Medallion from the Hungarian Government and the Franz Liszt Society in 1986.

Sudiarso's professional international activities include an invitation by the House of Composers (Russia) to attend the third International Music Festival at Leningrad, now St. Petersburg, in 1987. Other invitations came from the ASEAN Youth Music Workshop (Indonesia in 1983 and 1990, Philippines in 1984, Singapore in 1985, Thailand in 1986, and Malaysia in 1988), and the International Chopin Society, the latter to attend the International Chopin Piano Competition XII in Warsaw, Poland in 1990.

Since her return to Indonesia in 1964, Sudiarso has held several prominent positions of leadership nationally, notably in Dewan Kesenian Jakarta, ${ }^{3}$ which she served as the chair from 1973-1981 and 1986-1989, and Yayasan Pendidikan Musik, ${ }^{4}$ which she served as the senior lecturer and as the current headmaster of the school.

I attended Yayasan Pendidikan Musik from 1987-2000, and I had the privilege of studying with Sudiarso from 1996 through 2000, an experience which brought personal knowledge of her teaching. I was aware of her legacy both in performing and also in teaching. I knew that her students were all good and that they mostly went abroad to continue their music careers. Beginning with the first lesson, Sudiarso taught me that being a professional required seriousness, dedication, discipline, and good work ethic. For the next four years that I studied with her, I learned how to be a professional, even at a relatively young age. Her previous successful students certainly became models for me, not only in music but also in life.

\footnotetext{
${ }^{3}$ It was an institution whose function was to support and develop any musical activities with the province of Jakarta. The institution was formalized by Ali Sadikin, the governor at that time, on June 17, 1969.

${ }^{4}$ The school is the oldest music academy in Jakarta, and it approximately has 2000 students. The school has two locations, Manggarai and Bintaro, both in the southern part of Jakarta.
} 
Many of Sudiarso's students before and after my graduation continued their musical journeys, and many of them became professional pedagogues, concert pianists, conductors, or composers. The careers of almost all successful Indonesian musicians have intersected with Sudiarso at some point. Examples of her successful students are Dr. Johannes Sebastian Nugroho (pedagogue and composer, a graduate from Indiana University) and Levi Gunardi (concert pianist, a graduate from Manhattan School of Music); it is their compositions, dedicated to her, which will be analyzed in this study. Other successful Indonesian musicians who previously studied with Sudiarso are, among others, Adelaide Simbolon (collaborative pianist and pedagogue, a graduate from University of Wisconsin), Nikodemus Indrakusuma (music theory lecturer at Universitas Pelita Harapan), Dr. Kuei Pin Yeo (concert pianist, a graduate from Manhattan School of Music), Dr. Cecilia Indah Yudha (concert pianist and composer, a graduate from University of North Carolina Greensboro), Harimada Kusuma (concert pianist, a graduate from Rotterdam Conservatory), Ruth Wibisono (pedagogue, a graduate from Hogerschool voor de Kunsten Utrecht), and Ivana Fidelia Tjandra (pedagogue, a graduate from University of Northern Iowa).

\section{Justification for the Study}

In Indonesia, interest is growing rapidly in Western classical music and quickly expanding at formal schools, music schools/academies, and universities. Sudiarso's contributions are known throughout the country among musicians and she has been recognized by the national government, in part through her "Pianist and Music Educator" title given in 2008 by Dr. Meutia Hatta, Minister of State for Women and Child Protection. There are several ways that Sudiarso's

$5 \overline{28,2013)}$. "Iravati M. Sudiarso," Wikipedia, http://id.wikipedia.org/wiki/Iravati M Sudiarso (accessed March $28,2013)$. 
former students have identified and responded to her teaching legacy, including composing pieces dedicated to her; however, no one has written any factual documentation and discussed her teaching in a scholarly way, neither in the Indonesian language nor in English.

This current research discusses Iravati M. Sudiarso's stature as a piano master teacher in Indonesia. No research studies comprehensively documenting Sudiarso's professional life, performances, and teaching legacy are available worldwide. Because there is virtually no scholarly literature about her, the best source of information is to consult and collect testimonials from her former students and colleagues who have established themselves in the world of music. During her more than forty years teaching, her legacy has been transmitted orally through her dedication to teaching; therefore, the responses from these professionals will be crucial. This research will serve as a significant resource for knowing this piano master teacher and her impact on the careers of almost all successful Indonesian musicians.

\section{Purpose of the Study}

The purpose of this study is to document the teaching legacy of Iravati M. Sudiarso by gathering information in order to provide a comprehensive resource for musicians, scholars, and pedagogues. This study discusses how her contributions and professional presence has shaped and impacted the musical landscape of Indonesia. Specifically, this project addresses the following research questions:

1. What led Sudiarso to embark on her professional career as a pianist?

2. During the past forty years, how important is Sudiarso's contribution to classical music in Indonesia?

3. What is Sudiarso's teaching philosophy and style for transferring her knowledge to students? 
4. How have her students identified with and responded to her teaching legacy? One indication of her esteem is the compositions dedicated to her by former students. In chapter seven, I present analyses of two piano compositions by Johannes Nugroho and Levi Gunardi, both of whom are reputable composers and concert pianists.

\section{Limitation of the Study}

There is plenty of literature discussing Indonesian musical styles and how they contribute to the writing styles of some Western composers. Several library databases have extensively discussed musical elements of Indonesia, especially The Garland Encyclopedia of World Music (South East Asia), Worlds of Music, and The Online New Grove Music. ${ }^{6}$ Nevertheless, there is no comprehensive literature on Indonesian pianists and Indonesian piano music, neither in Indonesian nor in English. The databases reveal only one resource that analyzes selected solo piano works by contemporary Malaysian and Indonesian composers from 1979 to 2007, a dissertation by Charmaine Blythe Siagian; this monograph provides an overview of contemporary solo piano works by seven Malaysian and Indonesian composers, including Chong Kee Yong, Ng Chong Lim, Tazul Tajuddin, Tan Chee-Hwa, Slamet Abdul Sjukur, Michael Asmara, and Ananda Sukarlan. ${ }^{7}$

An exhaustive survey of Sudiarso's former students and other professional colleagues was not possible due to their widely scattered locations. Therefore, the origins of this document

\footnotetext{
${ }^{6}$ Pinkcheer Shintai Tamio, "The interpenetration of Indonesian and Western elements in Trisutji Djuliati Kamal's 'Sunda Seascapes"' (DMA diss., West Virginia University, 2007), 2.

${ }^{7}$ Charmaine Blythe Siagian, "Selected Solo Piano Works by Contemporary Malaysian and Indonesian Composers from 1979 to 2007: An Introduction" (DMA diss., The University of Oklahoma, 2007), vii-viii.
} 
will consist only of my own research, analysis, and my previous direct correspondence with Sudiarso, Nugroho, Gunardi, and other colleagues whom I know personally.

For these reasons, the best available resources come from Sudiarso's former students and colleagues, along with my own memories of studying with her for four years at Yayasan Pendidikan Musik music school.

\section{Research Design}

This research document consists of eight chapters. Chapter Two, "Research Question and Methodology," will explore Sudiarso's contribution to the musical landscape of Indonesia. The research questions as described above in "Purpose of the Study" will be used as a guide for the research. This chapter will also provide a means of access to necessary documents and available human resources regarding this research, including my personal experience as Sudiarso's former student and correspondence with other previous students.

Chapter Three, "Biography and Professional Career,” will outline Sudiarso's life and career as a professional pianist, including a brief biography and information about her studio at Yayasan Pendidikan Musik music school in Jakarta.

Chapter Four, “Aspects of Sudiarso's Teaching,” will outline Sudiarso’s teaching career, including how she chooses students, the importance of teaching for her, the demanding nature of her lessons, her technical exercises, her demonstrations at the piano, her studio-class and recital reminders, and the support she receives from Yayasan Pendidikan Musik music school.

Chapter Five, “Sudiarso Duo,” will discuss Sudiarso's career with her second daughter, Aisha Ariadna Pletscher. Born in 1971, Pletscher graduated from the pre-conservatory program of Yayasan Pendidikan Musik music school in 1987 and continued her study at the Manhattan School of Music. 
Together they formed the Sudiarso Duo in 1993, and have actively maintained an international performing schedule, most recently in Prague, Godöllö, Brastislava, and Bangkok.

Chapter Six, "The Music," will outline some of the repertoire I studied with Sudiarso, including Chopin Etudes, Op. 25 no. 1 and no. 12; Liszt Paganini Etude no. 5; Prokofiev Etude, Op. 2 no.4; Chopin Sonata no. 2; Mendelssohn Rondo Capriccio, Op. 14; Rachmaninoff Prelude, Op. 23 no. 5; and the Schulz-Evler Concert Arabesque on the "Blue Danube."

Chapter Seven, "Citra and Happy Birthday," will discuss some of the ways that Sudiarso's former students have identified and responded to her teaching legacy, including composing pieces dedicated to her. In this regard, I will provide analyses of two piano compositions by her previous students, Nugroho and Gunardi; both are well known as composers and concert pianists in Indonesia. Chapter Eight, "Conclusion," will summarize the results of my study and will provide suggestions about continuing Sudiarso's legacy in the developing musical life of Indonesia. 


\section{CHAPTER II}

\section{RESEARCH QUESTIONS AND METHODOLOGY}

\section{Studies with Related Methodology}

As already discussed in Chapter 1, there are only a few articles have been published about Sudiarso or her teaching.

Internet searches and extensive searches of library databases were conducted to find similar research that could serve as a model for this paper. The keywords that I used for searching were "piano teachers," "master teachers," "legacy," "lineage," "and "piano teaching."

In the databases there are a number of available sources listing similar scholarly studies of other master teachers. Examples include specific studies of Menahem Pressler, ${ }^{8}$ Marvin Blickenstaff, ${ }^{9}$ and Daniel Ericourt. ${ }^{10}$ These studies provide useful models for the structure of this topic and possible methodologies for research.

William Brown wrote a book about Menahem Pressler, his piano professor during his study at Indiana University. The research discusses Pressler's approach to performance and teaching as well giving images to guide the pianist's creativity toward expressive interpretation. During the course of writing the book, Brown used many direct quotations as a result of interviewing many people. Musical scores, recordings, and transcripts of lessons with Pressler were also provided by a number of individuals. This book is the primary model for conducting my research.

In her dissertation, Ernst documents the legacy of master piano teacher Marvin Blickenstaff through an analysis of his philosophy and pedagogical style. She also discusses his contributions to the

\footnotetext{
${ }^{8}$ William Brown, Menahem Pressler: Artistry in Piano Teaching (Bloomington: Indiana University Press, 2009). ${ }^{9}$ Sarah Marie Ernst, "The legacy of master piano teacher Marvin Blickenstaff: His pedagogy and philosophy" (Ph.D. diss., The University of Oklahoma, 2012).

${ }^{10}$ Judie Foreman Hutton, "The teaching and artistic legacy of French-born pianist Daniel Ericourt" (DMA doc., University of North Carolina at Greensboro, 1993).
} 
field of piano pedagogy, especially during his professorship years at the University of North Carolina (Chapel Hill) and at Goshen College, as well as his presidency of the Board of Trustees of the Frances Clark Center for Keyboard Pedagogy. The primary resources for this study were Blickenstaff's publications and presentations, and recordings of his piano lessons and classes, interviews, and surveys. The purpose was to reveal how Blickenstaff's professional work impacted individuals within the field of piano pedagogy and established his philosophy and teaching style.

Hutton investigates in her dissertation the professional career of French-born pianist Daniel Ericourt, especially his contributions as artist-in-residence at The University of North Carolina at Greensboro from 1963 to 1976. Part two of the dissertation is a compilation of biographical data regarding Ericourt's educational and professional background, which influenced his artistic development and led to his career as pianist and pedagogue.

The databases reveal a huge number of available sources regarding keyboard pedagogy from the 1500 s to the twentieth century. It is clearly impossible to discuss each potentially relevant work within the scope of this chapter, in part because, to the best of my knowledge, only the few articles already mentioned refer to Sudiarso or her teaching. Examples of books about or by other piano teachers, in a chronological history of piano pedagogy, include such studies as Girolamo Diruta's Il Transilvano; Theodore Leschetizky's method, issued with his approval by his assistant Malwine Brée; Lawrence Scauffler's Piano Teaching: Myth or Science; Walter Gieseking's Piano Technique; and Gyorgy Sandor's On Piano Playing: Motion, Sound, and Expression.

Diruta (c1561-c1613) published the first and second part of Il Transilvano in 1593 and 1609 respectively; nevertheless, the complete editions or translations were for many years missing. ${ }^{11}$ The treatise is significant as it is the first treatise in Italian to deal exclusively with keyboard music; the

\footnotetext{
${ }^{11}$ Girolamo Diruta, Il Transilvano (1593, 1609) (The Netherlands: Frits Knuf Buren, 1983), 9.
} 
first to distinguish harpsichord and organ playing; and the first to describe sixteenth century Venetian school of keyboard music. The treatise is named after Sigismund Bathori, a ruler of Transylvania (region in the central part of Romania) from 1588 to 1598 . The treatise discusses four concerns: The first is Diruta's technique and style of playing after he met Andrea Gabrieli and Claudio Merulo, with further discussion of how to play from an intabulation (a keyboard score) or from a partitura (an open score), along with proper embellishments. ${ }^{12}$ The second concern is a study of species and imitative counterpoint. The third concern regards modes, while the fourth discusses additional important skills for an organist, including musical rhythm and the art of singing.

Perhaps because the "Leschetizky method" became so famous, Leschetizky himself spoke of not believing in any kind of piano method. He stated, "Even in technique it is impossible to have a method, for every hand is different. I have no method and I will have no method. Adopt with your pupils the ways that succeed with them, and get away as far as possible from the idea of a method. Write over your music-room door the motto: NO METHOD!"13 His assistant, Malwine Brée, who was his pupil for more than ten years, tested Leschetizky's "method" on hundreds of pupils. Brée states, "I am all aware that a finished pianist can no more be formed by a theoretical method alone than a painter or sculptor can be trained by books on painting or sculpture." ${ }^{.4}$ The book discusses sitting position, hand position, tools for technical development (including wrist exercises, finger exercises, scales, triads, chords, octaves), embellishments, glissando, dynamics, pedal, rules for performance (melody-playing, tempo, rhythm, arpeggio), fingering, practice, and movements of the hand and arm.

\footnotetext{
${ }^{12}$ Ibid, 11.

${ }^{13}$ Marienne Uszler, Stewart Gordon, and Elyse Mach, The Well-Tempered Keyboard Teacher (New York: Schirmer Books, 1991), 321.

${ }^{14}$ Malwine Brée, The Groundwork of the Leschetizky Method (New York: Haskell House Publisher, 1969), iii.
} 
Lawrence Schauffler was the head of the piano department of the State Normal School at Fredonia, NY. The purpose of his 1937 book was to provide answers to the some of the fundamental questions about piano technique, since many other books at that time were either outdated or written in highly technical language. ${ }^{15}$ The book has two parts, which discuss interpretation and hand physiology respectively. The first part includes question, color, answer, imagination, and "secrets," while the second part includes the touch, the forearm, the hand, the fingers, lateral arm movements, and fingering.

Walter Gieseking in his Piano Technique actually includes two complete books The Shortest Way to Pianistic Perfection and Rhythmics, Dynamics, Pedal and Other Problems of Piano Playing. The book mainly discusses his method of piano playing, which he studied with Karl Leimer from 1912 to 1917. Leimer addressed the importance of self-control and critical self-hearing, which in Gieseking's opinion is the most important factor in all of music study. "Playing for hours without concentrating the thought and the ear on each note of the certain study in hand is wasted time! Only trained ears are capable of noticing the fine inexactitudes and unevenness, the eliminating of which is necessary to a perfect technique." ${ }^{\prime 16}$ The book discusses foundation of Gieseking's method, beginning music that students work at (Bach's two-part invention and three-part invention; and Beethoven's sonata in F minor, Op. 2 no. 1), natural interpretation, making study count, and special technical problems.

Gyorgy Sandor presents his On Piano Playing in three parts: the determining factor in piano technique; basic technical patterns; and technique becomes music. "The purpose of the book is to clarify concepts of piano playing, describe and organize fundamental elements of technique, and

\footnotetext{
${ }^{15}$ Lawrence Schauffler, Piano Teaching: Math or Science (Chicago: Gamble Hinged Music Company, 1937$), 1$.

${ }^{16}$ Walter Gieseking and Karl Leimer, Piano Technique (New York: Dover Publication, Inc., 1938), 5.
} 
indicate how to apply these elements in performance. ${ }^{, 17}$ The book describes proper coordination and physical motion, along with full consciousness in practicing to produce good tone; after all, the art of technique should give freedom to a performer for full interpretations. "The art of piano technique begins at the point where technical problems have already been resolved and where a sophisticated technique serves the creative purpose of the interpreter."18

\section{Research Procedures and Documentation}

The research for this study was conducted by discovering, collecting testimonials, and analyzing as many resources as possible. All related materials, documents, and human resources (Sudiarso's former students) were used for the purpose of the research. A summary follows of the research procedures:

1. Collect many testimonials, especially from Sudiarso's former students and colleagues, to gather information regarding their remembrances of studying with her. Professionals whom I contacted were:

a. Addie Muljadi Sumaatmadja (a current music director and conductor of Twilite Symphony Orchestra).

b. Sudirman Leman (guitarist, a graduate from University of Music and Dramatic Arts, Graz, Austria).

c. Ivana Tjandra (pedagogue, a graduate from University of Northern Iowa).

d. Susiana Aditjhan (current teacher at Yayasan Pendidikan Musik).

\footnotetext{
${ }^{17}$ Gyorgy Sandor, On Piano Playing (New York: Schirmer Books, 1981), ix.

${ }^{18}$ Ibid, xii.
} 
e. Johannes Nugroho (concert pianist and conductor, a graduate from Indiana University).

f. Levi Gunardi (concert pianist and conductor, a graduate from Manhattan School of Music).

g. Delima Simamora (vocalist, current lecturer at Universitas Pelita Harapan).

h. Laksmi Soedibjo (current teacher at Yayasan Pendidikan Musik).

i. Harimada Kusuma (concert pianist, a graduate from Rotterdam Conservatory).

j. Eddy Sutanto (director of Staccato ${ }^{19}$ magazine).

k. Erick Hidayat (a graduate Anton Bruckner Konservatorium and former teacher at Yayasan Pendidikan Musik).

1. Alfred Situmorang (concert pianist and current lecturer at Universitas Pelita Harapan).

2. Gather information from Yayasan Pendidikan Musik music school regarding Sudiarso's career.

3. Communication with Levi Gunardi, the current vice director of academic affairs at Yayasan Pendidikan Musik.

4. Communication with Johannes Nugroho and Levi Gunardi to discuss the composers' individual approaches and their perspectives regarding their music "Citra" and "Happy Birthday," along with their own biographical details.

5. Solidify the final version of the research.

\footnotetext{
${ }^{19}$ Staccato is an educational and informative magazine that discusses musical trends in Indonesia. It is published once a month by Staccato as a company in Sidoarjo, East Java.
} 


\section{CHAPTER III}

\section{SUDIARSO'S BIOGRAPHY AND PROFESSIONAL ACTIVITIES}

\section{Professional Study and Performances}

Iravati Mangunkusumo Sudiarso grew up as the second child of five in the family of Darmawan and Hestia Mangunkusumo. She was born on September 28, 1937, in Surabaya, East Java. For many years, members of the Mangunkusumo family had been active in the country's political life. Her father, Darmawan Mangunkusumo, was the former Minister of People Welfare during the leadership of Sukarno, the first president of Indonesia. He was also the younger brother of Tjipto Mangunkusumo, a prominent Indonesian independence leader and Sukarno's political mentor.

Sudiarso has loved music ever since her early years and it has been part of her daily life.

She remembers about her early age:

My father owned a huge collection of LP (Vinyl) records that included classical music and even Klenengan (Javanese Gamelan). They were played every day. Like it or not, we listened to them. ${ }^{20}$

She develops her love for any kind of music: Western classical music, Javanese music, and also jazz music. Her father was a collector of fine paintings. She says that all her family members were frequently exposed to the beauty of all the arts, not just music.

Everyone was involved, but we were also fond of traditional Javanese music. Our father was also a painting aficionado and we liked seeing them as well. So everything felt complete. We were nurtured with the world of the aesthetic. I also liked jazz music; but I remember vividly that it was forbidden to play jazz music on the radio during Sunday. $\mathrm{He}$ said that no jazz music the B Minor [Mass] from Bach, for instance. ${ }^{21}$

\footnotetext{
${ }^{20}$ Rakaryan Sukarjaputra, Tonny Widiastono, and Efix Mulyadi, “Lebih Jauh Dengan Iravati M. Sudiarso,” [Going Deeper with Iravati M. Sudiarso] Kompas (Jakarta), June 30, 1996.

21 Ibid.
} 
Her father would play music and all the children had to know the composers and pieces being played. Her parents also made rules at home regarding language proficiency.

Monday was the time for speaking in Bahasa Indonesia, Tuesday was for speaking in Dutch, Wednesday was for German, Thursday was the time for Javanese (since the night before Friday is a very crucial time for Javanese people), and then Friday was for French. It went on and on like that. If we spoke in a language different from the assigned one, it would not yield any response or reply. ${ }^{22}$

Sudiarso showed her talent very early. Her mother saved all of her own salary to buy a used piano for Iravati.

My fingers were too short during that time, but I was able to imitate the song "Bengawan Solo."23

Sudiarso immediately began her piano lessons under the guidance of her mother, Hestia Mangunkusumo, before continuing with Netherland pianists Madlener and Henk de Strake. As early as thirteen years old, she knew that she wanted to be a professional musician. In 1949, because of her father's job, Sudiarso moved to the Netherlands, where she spent her high-school years as a Lyceum student in Den Haag. Sudiarso had further professional musical training in 1955, when she studied piano with Richard Mayer and with the famous pianist-composer Leon Orthel at Koninklijk Conservatorium, Den Haag; she graduated in 1958.

In 1962, Sudiarso was awarded a Fulbright scholarship from the United States

Government to advance her musical study at the Peabody Conservatory of Music, Baltimore,

Maryland. This brought on a time of confusion for her:

Well, I was forced to be separated from my family, from my child who was at her cutest moment; she was only two years old at that time. It was very difficult. The story was that when I returned home to Jakarta, I got offered a Fulbright scholarship to study in America. I was hesitant, but then I was informed that if I didn't take it, it would be granted to a pianist from Korea. My sense of patriotism awoke. As an Indonesian, I had

\footnotetext{
${ }^{22}$ Ibid.

${ }^{23}$ This is the title of a famous Indonesian song about the Java island's longest river, located in Surakarta, Central Java.

Ibid.
} 
to take this opportunity. I consulted this with my husband. My husband asked me whether going back to school would make me happy or not, and I responded it with a yes. So, I set forth. It was fortunate that my mother was always there to help taking care of Dita, the oldest child. $^{24}$

Sudiarso enrolled for study at Peabody where she was under the guidance of internationally-acclaimed pianists Walter Hautzig and Mieczyslaw Munz. She completed all the requirements for Peabody's Bachelor and Master of Music degrees in only two years combined. She graduated in 1963 with her Bachelor's degree and was awarded the Florence Salomon Memorial Award during the same year, a prize presented for the highest achievement in piano. During the same year, Sudiarso was selected as the first Asian pianist to play with the New York Philharmonic for the opening of the Lincoln Center for the Performing Arts. After completing her Master's degree in 1964, Sudiarso returned to Indonesia. She describes this moment of heartbreak as a mother:

As I have said before, the price that I had to pay was not cheap. When I returned home, my own child no longer recognized me. It was a heavy blow for me. When I left her she was two years old. When I met her again she was six years old - and when I wanted to hug her, she refused. That is a mind-blowing thing for any mother. ${ }^{25}$

Sudiarso's performing career includes numerous solo and collaborative recitals. Her concerto recitals include performances with such orchestras as Koninklijk Conservatorium Den Haag Symphony Orchestra, New York Philharmonic Orchestra, Tasmanian Symphony

Orchestra, The Australian Chamber Orchestra, Jakarta Ensemble Orchestra, Jakarta Symphony Orchestra, Radio Republik Indonesia Orchestra, Twilite Orchestra, and Nusantara Chamber Orchestra, collaborating with Louis Stotijn, Dobbs Franck, Richard Tognetti, Suka Hardjana, Adidharma, F.X. Soetopo, Lim Kek Tjiang, Lim Kek Tin, Addie Muljadi Sumaatmadja, and Yazeed Djamin.

\footnotetext{
${ }^{24}$ Ibid.

${ }^{25}$ Ibid.
} 
Her series of performances with the New York Philharmonic for the inauguration of Lincoln Center for the Performing Arts ran for five weeks. About this experience, Sudiarso states:

Yes, but there is a fluke factor behind that story. So, there is no need to exaggerate it. I was still going to school at that time in the United States of America, in the year 1963, if I am not mistaken. For five straight weeks, I performed as a soloist with the New York Philharmonic Orchestra, building an art center, the Lincoln Centre (for the Performing Arts) in New York. Perhaps people remembered me due to my Asian heritage. At that time, an Asian playing the piano was still viewed as something bizarre. ${ }^{26}$

\section{Yayasan Pendidikan Musik Music School}

Iravati Sudiarso has been teaching in Yayasan Pendidikan Musik since 1969; thus, 2013 marks her forty-fourth anniversary. She served for many years as the school's academic director; currently she is the headmaster. Almost every day Sudiarso can be found in her piano studio, Room 10, in Yayasan Pendidikan Musik Manggarai. Her daily teaching schedule is usually after lunch until nine p.m. She is healthy and her energy in teaching seems immeasurable in that she always gives full focus to every student. Her work ethic is such that she rarely cancels any lessons or concerts; when she cannot avoid missing an appointment, she will always replace it. Susiana Aditjhan, one of her former students said: "Sudiarso is disciplined, hardworking, and highly dedicated - all for our better purposes. ${ }^{, 27}$ Erick Hidayat, a former lecturer at Yayasan Pendidikan Musik, stated: "Before anyone else really did so in Indonesia, Sudiarso set a very strict quality control that has defined generations of pianists. Her calling for dedication has also shaped YPM into what it is today." 28

\footnotetext{
${ }^{26}$ Ibid.

${ }^{27}$ Susiana Aditjhan, emailed to Mario Santoso, Morgantown, WV, April 4, 2013.

${ }^{28}$ Erick Hidayat, emailed to Mario Santoso, Jakarta, Indonesia, July 10, 2013.
} 
For more than forty years, Sudiarso has typically taught thirty students each year. It is fascinating that she teaches such a demanding schedule while maintaining an active performing career at the same time. Both as performer and also as teacher, Sudiarso has shaped the musical landscape of an entire country. Many of Sudiarso's students have been successful in establishing themselves as reputable musicians both in Indonesia and abroad.

A feature of Sudiarso's teaching is to build characters for each piece that fit each student's personality, while listening for as much color as possible. Her teaching style is very detailed, from technical issues to the development of artistry. She always tells us to get rid of any tension:

Tension is good and it will be there; but it has to be released as soon as you touch the key. $^{29}$

An example is when she criticized my performance of Liszt Hungarian Rhapsody No. 2:

Mario, what is your intention? Play as loud as possible and thus divide the piano into two pieces? Is it necessary to play that strongly? What is the meaning of forte? ${ }^{30}$

I will discuss additional aspects of teaching in Chapter Six, "The Music," in which I outline some of the music I studied with her, including Chopin Etudes, Op. 25 No. 1 and No. 12; Liszt Paganini Etude No. 5; Prokofiev Etude, Op. 2, No. 4; Chopin Sonata No. 2; Mendelssohn Rondo Capriccio, Op. 14; Rachmaninoff Prelude, Op. 23, No. 5; and the Schulz-Evler Concert Arabesque on the "Blue Danube."

Being selected to enter her studio is something to be proud of. It was May 1998 when I passed "Level Six" in the piano examination system at Yayasan Pendidikan Musik; this was the last and deciding level that determined whether a student could continue to the pre-conservatory

\footnotetext{
${ }^{29}$ My own remembrance of her teaching during my study at Yayasan Pendidikan Musik music school. ${ }^{30} \mathrm{Ibid}$.
} 
program at the school. I became eligible to enter the pre-conservatory program since I passed the minimum score requirement of $80 .^{31}$

The admitted students had opportunity to express preference for their choice of teachers and could audition specifically for the individual teachers. Many students tried to audition for Sudiarso, as the most desired teacher in that school. Although it was not always the case, Sudiarso tended to select the three students who received the highest grades from level six each year. I was not admitted to her studio on my first attempt, but later she contacted my previous teacher to say that she had agreed to accept and teach me.

When I heard this wonderful news, I was so thrilled to be part of her studio since I was aware of her legacy both in performing and also in teaching. I knew that her students were all good and that they mostly went abroad to continue their music careers. Beginning with the first lesson, Sudiarso taught me that being a professional required seriousness, dedication, discipline, and good work ethic. During the next four years that I studied with her, I learned how to be a professional, even at a relatively young age. Her previous successful students certainly became models for me, not only in music but also in life.

When students pass the third level of pre-conservatory program under the tutelage of Sudiarso, they must bring at least 18 pieces to performance level. Sudiarso always gives two etudes, one polyphonic piece, one sonata (eighteenth or nineteenth century), and two character pieces each year; and if students are able to finish them before the end of the year, she will give

\footnotetext{
${ }^{31}$ The annual examination system at Yayasan Pendidikan Musik is as follows: pre-elementary and elementary; level $\mathrm{I}-\mathrm{VI}$; pre-conservatory level I-III. The jury panel includes the entire piano faculty of the school. The nature of this examination is so demanding and the level is so high that students who complete the third level of preconservatory program are highly sought after for jobs in any local or national music schools in Indonesia to teach beginner-to intermediate-level students. Those who earn the three highest grades of the examination usually continue their careers in music abroad, and they are mostly Sudiarso's students.
} 
new repertoire. Sudiarso also holds repertoire class ${ }^{32}$ about once a month, and more often when approaching the annual examination. In summary, students who pass their study with Sudiarso are ready for more advanced musical training.

${ }^{32}$ Sometimes called "studio class" in America. 


\section{CHAPTER IV}

\section{ASPECTS OF SUDIARSO'S TEACHING}

\section{Sudiarso as a Teacher}

Long known as a reputable Indonesian pianist and teacher, Sudiarso's teaching and performing has produced successful generations of pianists for more than forty years. She is perhaps famous as the most dedicated teacher who works tirelessly towards a better future for her students and for the entire musical landscape of Indonesia. One of her best former students,

Levi Gunardi, who has established himself as a reputable concert pianist and composer, states:

Sudiarso is a teacher who never stops teaching or conveying the love of music to her students. She also teaches her students how to appreciate and respect the music that they learn, both the composer and the music itself. She also instills a sense of discipline within her students, especially in working on their pieces patiently and specifically. Sudiarso also teaches the importance of being humble in sharing music. ${ }^{33}$

Alfred Situmorang, current lecturer at Universitas Pelita Harapan adds:

Sudiarso has the highest idealism in music that automatically ensures the highest quality of a performance. Her personally inspirational story regarding her meeting with Arthur Rubinstein and Maria Callas while in Europe emphasizes the importance of simplicity in music, which is possibly the hardest thing to do."34

Ivana Tjandra, a former student of Sudiarso, adds:

Tante Ira always taught with passion. She brought the real music world to me through her past experiences in theater, politics, stage performance and competitions. She often talked about her life as a way to help me understand the bigger picture - not just anything related to piano playing, but also the history and gossip stories behind the music or performance practice. She was very generous with her time and knowledge. She described and demonstrated in every way she could to help me understand better ways to play. she never compromised regarding quality of playing. Through her piano studio, she built a good and healthy culture of friendship in music and at the same time also healthy

\footnotetext{
${ }^{33}$ Levi Gunardi, emailed to Mario Santoso, Morgantown, WV, April 6, 2013.

${ }^{34}$ Alfred Situmorang, emailed to Mario Santoso, Jakarta, Indonesia, July 10, 2013.
} 
competition among students as a motivation always to move forward, recognizing each other's strength and weaknesses and helping each other to be better. ${ }^{35}$

After Sudiarso completed her Master's degree at the Peabody Conservatory of Music in 1964, she returned to Indonesia and contributed developing arts and music in Jakarta, especially when Ali Sadikin, the governor of Jakarta at that time, supported the building and inauguration of Taman Ismail Marzuki. ${ }^{36}$ Sudiarso was the chair of Dewan Kesenian Jakarta(Jakarta Arts Council) in 1973-1981 and 1986-1989. She also taught in the Jakarta Institute of Arts from 19751979. But her primary teaching venue was the Yayasan Pendidikan Musik music school.

\section{Selecting Students}

Iravati M. Sudiarso has dedicated herself to teaching in Yayasan Pendidikan Musik music school for forty-four years. She has taught hundreds of piano students and produced successful generations of musicians during her teaching career.

What Sudiarso looks for in prospective students is their full commitment to music.

Regarding her highly selective decision in choosing students, Johannes Nugroho stated:

She is very strict with her students regarding their obligations for artistic responsibility. Thus, she emphasized strongly to her students that this piano study is a very serious endeavor that must demand and absorb the totality of one's being. To me personally, this is her greatest legacy. This is what makes her successful and more than just a mere piano teacher - she is someone who will transform her students to have the right perspective and attitude regarding the art in music. From here, true and sincere appreciation of this beautiful art will open the gate of exploration, so that we can discover both the potential within and the wealth of the field outside. ${ }^{37}$

\footnotetext{
${ }^{35}$ Ivana Tjandra, emailed to Mario Santoso, Jakarta, Indonesia, July 10, 2013.

${ }^{36}$ This is an art and cultural center located at jalan Cikini Raya 73, Central Jakarta, Indonesia. This complex includes Jakarta Art Institute and Jakarta Planetarium. Taman Ismail Marzuki has six modern theatres for performing arts, exhibition hall, gallery, archive building, and cinema. Here is the link to their website http://www.tamanismailmarzuki.com/index.php

37 Johannes Nugroho, emailed to Mario Santoso, Morgantown, WV, April 5, 2013.
} 
Sudiarso also stresses the importance of love and faith in music, two important ingredients for being a good musician. She then looks for whether her prospective students are motivated to continue their musical journeys to the next professional levels, either to begin teaching or to continue their studies in a conservatory. She serves as a model for her students; she likes to tell stories that inspire us, often from her own life. Eddy Sutanto, the director of Staccato magazine, states:

Iravati Sudiarso is a perfect figure in two regards, as a pianist and as a teacher. As a pianist, she has tremendous knowledge and skills, yet remains humble. As a teacher, she is firm, disciplined, highly dedicated to her profession, and a humanistic figure. ${ }^{38}$

All her students are supportive of one another, calling themselves the "IMS class.",39 There are usually three to five students, called wali kelas, ${ }^{40}$ whose function is to organize studio classes, teach others when Sudiarso is not available due to recitals, and take care of her music library in Room 8A. When she is not available, Sudiarso also has her students run studio classes for themselves.

\section{The Importance of Teaching}

Teaching is everything for Sudiarso; her love of music education is so deep that no one equals it in the entire country. Sudirman Leman states in his testimonial to Sudiarso's legacy:

She is indeed one of the pioneers and important figures in Indonesian musical education. Her firm personality and vision regarding education truly gives inspiration not only to the next generation but also to her colleagues. Although some of her decisions are rather controversial, she will always be consistent with her mission. Her commitment and integrity are something special that is rare in Indonesia. ${ }^{41}$

Sudiarso always encourages what comes from the students' own insight and personality, and thus pushes them to express music to its climax.

\footnotetext{
${ }^{38}$ Eddy Sutanto, emailed to Mario Santoso, Morgantown, WV, April 5, 2013.

39 IMS stands for Iravati M. Sudiarso.

${ }^{40}$ Class deputy.

${ }^{41}$ Sudirman Leman, emailed to Mario Santoso, Morgantown, WV, April 5, 2013.
} 
Sudiarso appreciates every individual's physical condition and musical talent. She believes that different physiques combined with unique personality create wonderful music.

She once said in the studio class:

There might be five different people playing Chopin Ballade No. 1, but they will not play in the same way. Although the music has already been written in the score, every personality will recreate it differently. ${ }^{42}$

She believes that it is important to recreate the music rather than creating.

The music has been written for ages and we are grateful for those wonderful composers. They may have passed away, but their music as art will never fade away. There is no way to create the music in performing because it has already been composed; but recreating it is another story. Let your unique personality perform it. A pianist is someone who plays piano; but an artist is someone who creates art with his/her unique personality. ${ }^{43}$

\section{The Demanding Nature of Her Lessons}

Once they are admitted into the studio, students immediately realize that Sudiarso demands and expects a lot from them. Everyone is aware of her legacy both in performing and also in teaching. Sudiarso once said, "I give my dedication; so you must also." Laksmi Soedibjo added:

When I came to the first lesson with Sudiarso, I immediately felt such a huge transformation not only in music but also in my character. There were ups and down, but they gave me experience to be more open-minded; it was difficult at first, but I believe that these challenges had a positive impact on me and my values. What I learned the most from Sudiarso is that I need to work very hard with discipline and not give up in learning. To have talent is good, but hard work is much more important; with no hard work, talent means nothing. I have held this concept and shared it with all my students. ${ }^{44}$

Sudiarso always asks students if they have warmed up prior to the lesson. She will not start the lesson unless we are ready physically and mentally. Our minds also need to focus fully

\footnotetext{
${ }^{42}$ My own remembrance.

${ }^{43}$ Ibid.

${ }^{44}$ Laksmi Soedibjo, emailed to Mario Santoso, Morgantown, WV, April 6, 2013.
} 
on the music. Sudiarso consistently demonstrates caring for each student. She will always start by asking how we are doing in school or at home. Communication is very important, because teaching is not just a business for her; rather, it is a very personal relationship that needs to be nurtured.

Sudiarso expects students to fully grasp and master materials covered in the previous lesson. She does not require students to memorize a piece every week, but she expects students to know the composers and any markings written on the score. She rarely gives praise to students; this is not to discourage them, but rather to push them to keep working hard until they reach their best performance.

Sudiarso believes that faithfulness to the score is the highest obligation that students must consider. She once said:

"Respect to the score is the beginning of everything." 45

Again, a full understanding of all markings in the score is required before the lesson. After that is accomplished, she will start exploring with each individual's character and personality. She generally lets students choose their own interpretations as long as they still conform to the score. She likes to show examples of her playing, not for students to imitate, but rather for them to understand what they must try to convey to their listeners through the music.

Every note is important and it must convey something to listeners. ${ }^{46}$

She also tends to say something new during each lesson, for the sake of keeping the music fresh.

There is no way you can remember everything and thus play the same piece always in the same manner. Something has to change naturally just because the music is not dead. ${ }^{47}$

\footnotetext{
${ }^{45}$ My own remembrance.

${ }^{46}$ Ibid.

${ }^{47}$ Ibid.
} 


\section{Technical Exercises}

Sudiarso is always concerned with students' proper finger and arm motion.

The fingers must be strong, independent, and close to one another, whereas the arm must be free to support the fingers. ${ }^{48}$

She works tirelessly with individuals, since everyone's hands and fingers have different shapes. Sudiarso likes her students to play scales from slow tempo to faster tempo gradually; at each metronome marking they play a sequence of eight-note, triplet, and sixteenth note rhythmic value. Other than that, she rarely recommends any specific finger-training exercises. As she says: Technique comes from the mind. As long as you are clear how you want the music to sound, it will happen. ${ }^{49}$

\section{The Repertoire Class}

The repertoire class is held once a month in general, with increasing frequency as recitals and the annual exams approach at Yayasan Pendidikan Musik. Class attendance is mandatory for everyone--no excuses whatsoever! The class is very important, because it helps us prepare for recitals and other events before appearing in public. She always reminds us that performances in repertoire class must be treated the same way as if they were being performed in recital.

\section{Her Thoughts Regarding the Next Generation of Musicians in Indonesia}

Sudiarso believes that the younger generation of musicians in Indonesia has huge potential. If she speaks of the older generation, she mentions her admiration for Eduardus Halim

\footnotetext{
${ }^{48}$ Ibid.

${ }^{49}$ Ibid.
} 
from Bandung, West Java, who was the first Indonesian pianist to study at the Juilliard School.

She states:

A renowned pianist named Vladimir Horowitz, who passed away already, once stated that, generally speaking, Asian people are only good at imitating. But he confessed that he was "cured" of this stereotypical view thanks to the existence of Eduardus Halim. The world will be surprised that someone like him existed in this century. I was so proud when I read about it. Last year, he came here and played a gig. He graduated from Juilliard and he is still in New York. He convinced me that he is still Indonesian, complete with Indonesian passport. His Sunda is also fluent. Internationally speaking, he ranks at the top of Indonesia's younger generation. ${ }^{50}$

She is not pessimistic at all about the next generation. She believes that Indonesian

musicians include many strong talents. The only danger would be if these talents were influenced by people who do not transform them into strong characters. This is the reason that she keeps working hard.

Sudiarso observes that the musical development in Indonesia has been interesting.

There is an intriguing development going on. In the past, Jakarta only had YPM; but when Yamaha came along, a music course became a necessity. Abundant numbers of students are available. But what we need to focus on is the quality; in all honesty, for this to be enforced will be fairly difficult. So for the past 25 years, the process of trial and error has been conducted all across Indonesia regarding music education. Even the weird theories have been tried. ${ }^{51}$

\footnotetext{
${ }^{50}$ Rakaryan Sukarjaputra, Tonny Widiastono, and Efix Mulyadi, “Lebih Jauh Dengan Iravati M. Sudiarso" [Going Deeper with Iravati M. Sudiarso], Kompas (Jakarta), June 30, 1996.

51 Ibid.
} 


\section{CHAPTER V \\ SUDIARSO DUO}

Sudiarso established the "Sudiarso Duo" with her second daughter, Aisha Ariadna Sudiarso-Pletscher, in 1993; theirs is the first Indonesian mother-daughter duo. ${ }^{52}$ The duo maintains a busy performance schedule not only in Jakarta but also abroad. Their performances in Indonesia include, among others, the Jakarta International Performance Art Festival, the Schouwburg Festival at the Gedung Kesenian Hall in Jakarta; they have also appeared as soloists with the Jakarta Symphony Orchestra. They have also collaborated with several dance companies, working with Jajang Noer $^{53}$ and Sardono W. Kusumo ${ }^{54}$. In 2008, the duo went to Eastern Europe as representatives of Indonesian culture, performing in Prague (Czech Republic), Godőllö (Hungary), and Brastislava (Slovakia). The duo also performed in Bangkok, Thailand, in 2012 .

Aisha Sudiarso Pletscher was born in Bandung in 1971. She started her piano lessons at age three, under the guidance of her grandmother, Hestia Mangunkusumo. She enrolled at Yayasan Pendidikan Musik when she was four, studying with Jeanne Juwono, Etty Iskandar, and

Rudy Laban ${ }^{55}$. She then entered the pre-conservatory program for study with her mother and at graduation was given the YPM Artist Award ${ }^{56}$ After graduation, Pletscher briefly studied with

\footnotetext{
${ }^{52}$ Slovak Indonesian Chamber of Commerce, "Piano Concert Performed by Sudiarso Duo," SIOK, http://siok.sk/index.php/en/events/63-piano-concert-performed-by-sudiarso-duo.html (accessed April 6, 2013).

${ }_{53}$ Born on June 28, 1952 in Paris with original name Lidia Djunita Pamontjak. Her father is the first Indonesian diplomat in France.

${ }^{54}$ One of the pioneers in developing contemporary dance in Indonesia.

${ }^{55}$ Laban was the first headmaster of the school, a position he held until his passing in 2003.

${ }^{56}$ The school's most prestigious award.
} 
Reynaldo Reyes and Walter Hautzig in New York before attending Manhattan School of Music, where she studied with Solomon Mikowsky.

Pletscher has performed in Hong Kong, Algeria, the United States, and throughout Indonesia, both as a soloist and also as collaborative pianist. In 1999, she represented Indonesia at a commemoration in Jakarta of the $150^{\text {th }}$ anniversary of Chopin's death, along with pianists from France and Poland.

Pletscher has appeared as concerto soloist with such organizations as Tasmanian Symphony Orchestra, Australian Youth Orchestra, Long Island Youth Orchestra, Jakarta Symphony Orchestra, Jakarta Chamber Orchestra, Institut Seni Indonesia ${ }^{57}$ Orchestra, Remaja Jakarta Orchestra, Mahawaditra ${ }^{58}$ Orchestra, and Nusantara Chamber Orchestra; her collaborators have included Carlos Zappa, Dobbs Franks, Avip Priatna, Yudianto Hinupurwandi, Pipin Garibaldi, Rudy Laban, Praharyawan Prabowo, and Yazeed Djamin.
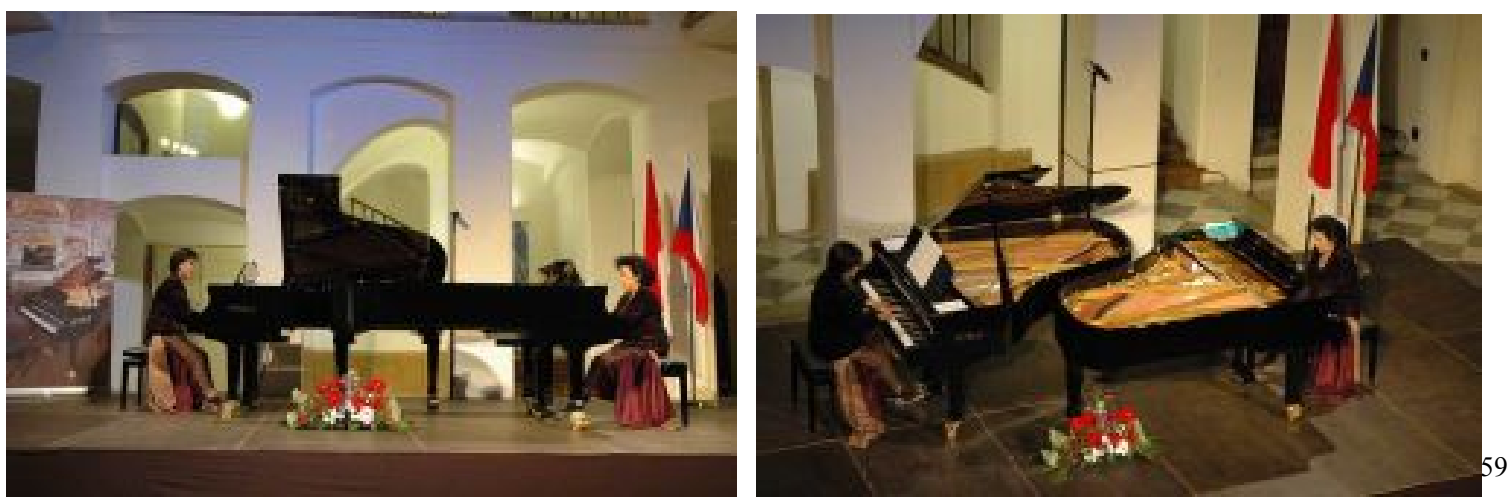

\footnotetext{
${ }^{57}$ Indonesia Institute of Arts, an instituted located in Jogjakarta, Central Java (www.isi.ac.id).

${ }^{58}$ The orchestra associated with University of Indonesia (http://mahawaditra.com/).

${ }^{59}$ Salim Said, "Sudiarso Duo Concert in Prague," Petrof, http://www.petrof.com/2008-indonesie-koncert.html (accessed April 8, 2013).
} 


\section{CHAPTER VI}

\section{THE MUSIC}

This chapter outlines some of the music I studied with Sudiarso, including Chopin Etudes, Op. 25 No. 1 and No. 12; Liszt Paganini Etude No. 5; Prokofiev Etude, Op. 2, No. 4; Chopin Sonata No. 2; Mendelssohn Rondo Capriccio, Op. 14; Rachmaninoff Prelude, Op. 23, No. 5; and the Schulz-Evler Concert Arabesque on the "Blue Danube."

\section{Etude in A-flat major, 0p. 25 no. $1^{60}$}

Sudiarso immediately showed me that, in order to play this etude, my arm must feel really free. She asked me to play very slowly and not to overstretch my fingers because "they must stay as close as possible. Try to maintain as normal and natural a hand position as possible and let the arm work for it." ${ }^{, 61}$ She then showed me how to practice "in rhythms," including systematic stops every two notes and every six notes, hands separately. She then asked me to play just the melody as if it were a soprano aria in the bel canto style, an approach that fits this music beautifully. As Antonio Tomassini wrote in The New York Times:

It is a wonder that Chopin, born in 1810, never tried to write an opera, because he was completely smitten with bel canto works, especially Bellini's. Chopin's melodies, like the opening theme for the soloist in the Piano Concerto No. 1, composed in 1830, sing with the long-lined, profoundly melancholic elegance of a bel canto melody. Chopin and Bellini sometimes seem like distant composer cousins drawing from the same creative well. $^{62}$

The next step was to play the melodic line together with blocked harmony and thus

express the singing melody and expressive harmony at the same time. I had to feel which

\footnotetext{
${ }^{60}$ I learned this etude in 1996 during my pre-conservatory level I studies.

${ }^{61}$ My own remembrance.

${ }^{62}$ Antonio Tomassini, "Bel Canto: Audiences Love It, but What Is It?" Music, http://www.nytimes.com/2008/11/30/arts/music/30tomm.html?pagewanted=all\& r=0 (accessed April 7, 2013).
} 
harmonies are "surprising" and to play them with different colors--either dynamic change or agogic timing. She then asked me whether I understood how to execute polyrhythm correctly, such as in measures seventeen to twenty. She also stressed the importance of knowing the structure of the piece, because that would guide listeners in the right direction; she also asked me to supply at least four or five different adjectives for each section, so that the words could guide me to an imaginative picture for each section. She then stressed the importance of performance practice, suggesting that Chopin's markings of forte and piano should be interpreted differently from forte and piano marks in music of the next century. The last discussion was about the leggierissimo touch throughout, which showed Chopin's tenderness in writing this etude. In that sense, being able to play this singing melody in an extremely subtle way was the ultimate goal of this etude.

\section{Etude in C Minor, Op. 25 no. $12^{63}$}

In this etude, it can be very challenging to find places to play softly. Regarding my sound, Sudiarso said to me: "You cannot just play everything loud. Are you going to break the piano into two pieces??64

I felt genuine passion for this etude, but apparently she thought that I did not understand the concept of producing a huge sound without being harsh; therefore, this was the first issue that we worked on together, as she had me play the etude in block chords. She said:

In order to produce a huge sound, you have to approach from the key; then the whole arm goes up. ${ }^{65}$

\footnotetext{
${ }^{63}$ I learned this etude in 1997 during my pre-conservatory level II.

${ }^{64}$ My own remembrance.

${ }^{65}$ Ibid.
} 
As a result, I learned to produce a big sound without forcing it. The second step in learning this etude was to play each pair of four-bar phrases "in rhythms," with fermatas every third and also every sixth note, corresponding to the hand groupings, but not to the meter. This arpeggio figuration requires a precise touch to manage the rapid repeated notes within each group of four notes. She suggested that I practice in slow tempo at piano dynamic level, accenting every beat, so that I could feel the delicacy of the piece; then I was to repeat the same exercise without accenting any notes. Only after I was able to do this step did she start increasing the speed; the accents would still be heard anyhow, but I was not to strike them.

\section{Sonata in B-flat Minor, Op. $35^{66}$}

Sudiarso explained first that Chopin mostly did not cope well with longer musical structures such as sonata and concerto, since he was best at composing character pieces. She started talking about the structure of the piece, highlighting the importance of differentiating the characters of the first and second themes. She wanted me to be clear about the very beginning, since it did not begin with the tonic; then we explored the doppio movimento and the controversy regarding where the repeat of the exposition should begin, as explained by Charles Rosen. ${ }^{67}$ She then stressed the importance of the rests between the two-note slur in the first theme, which contribute to the agitated feeling in the music. She mentioned that rests were also music--and I was not to ignore them!

\footnotetext{
${ }^{66}$ I learned this sonata in 1999 during my post pre-conservatory level III.

${ }^{67}$ Documentary evidence is explained in The Romantic Generation by Charles Rosen pages 279-280. This piece was published simultaneously in Leipzig, Paris and London. The Leipzig version has a double bar at the start of the Doppio Movimento section meant to indicate the beginning of a new and faster tempo. The dots which make it the start of the repeat appear to be an engraver's embellishment. The Paris and London versions are "correct" and the copy of the London version in the book has no double bar at all.
} 
Sudiarso then focused on how to balance the second theme: was it the same tempo as the first theme or slightly slower? Chopin did not mark any tempo difference there. She preferred the second theme to be slightly slower so I could express the lyricism. She taught me how to play tempo rubato properly.

Rubato means that you borrow tempo. Once you borrow, you have to return. In rubato, the left hand still serves as the conductor, while the right hand sings expressively without disturbing the main pulse. That is rubato. ${ }^{68}$

The stretto at the end of the exposition was to be pushed to create excitement. The treatment of recapitulation was generally the same. In the beginning of the development section, Sudiarso discussed what kind of sound the sotto voce meant. At that point in the piece, she gave me more freedom in tempo, since Chopin alternates developing the first and second themes; but she wanted the tempo to be strict during a sequence of the first theme. During the climax of the development section, the sequential pattern of the first theme, she worked with my left arm motion. In a manner similar to what she had suggested in the Etude in A-flat major, Op.25, No.1, she made sure that my arm was so free that I should not have any tension in this material.

\section{Liszt: Paganini Etude No. $\mathbf{V}^{69}$}

Sudiarso started explaining the importance of Franz Liszt, a grand figure with varied interests in the other arts as well, such as painting, nature, and literature. Although he turned inward and became a priest toward the end of his life, earlier in his career he brought the concept of composer/pianist to new heights of virtuosity. Sudiarso then discussed Nicolo Paganini, the great violinist. During much of the nineteenth century, these two composers were regarded as the

\footnotetext{
${ }^{68}$ My own remembrance.

${ }^{69}$ I learned this etude in 1996 during my post pre-conservatory level I
} 
champions of virtuosity. There were many composers who used themes by Paganini, for example Franz Liszt (Six Paganini Etudes), Robert Schumann (Caprices, Op. 3 and Op. 10), Johannes Brahms (Paganini Variations, Op. 35), and Sergey Rachmaninoff (Rhapsody on a Theme of Paganini).

She then explained that the purpose of this etude is to develop double stop and spiccato technique in violin. For stringed instruments, "double stop" means a technique of playing two notes simultaneously, while spiccato means a light bouncing of the bow on the strings. As written in the score of this etude, the upper line imitates the flute while the lower line imitates the horn. She then taught me how to do glissando both hands properly to produce good sound without hurting myself--use nails only! The next issue was how to move my arm fast enough for proper cross-hand technique. She asked me not to worry too much about keeping the tempo stable, because violinists and pianists both need time to change registers.

\section{Prokofiev: Etude in C Minor, Op. 2 no. $4^{70}$}

Sudiarso taught me that Prokofiev was an exciting composer in his use of harmony for a strong, yet playful, character. She said that, although the rhythmic and percussive elements were very important, I still needed to play it musically. This etude has restless running octave passages in the left hand, while the right hand has many different articulations: portato, accent, and staccato. I needed to make clear distinctions among these. The greatest difficulty appears in the left hand, due to its running octave figuration. Sudiarso asked me to depend completely on my arm and good rotation in order to do the passage, and not to focus too much on the left thumb so that I would not get tense. The second issue was to differentiate among the three articulations,

\footnotetext{
${ }^{70}$ I learned this etude in 1998 during my pre-conservatory level III
} 
portato, accent, and staccato, found in so much Russian music. The third issue was to shape the whole piece so it would not just sound loud.

\section{Mendelssohn: Rondo Capriccioso, 0p. $14^{71}$}

There were several technical issues regarding this piece. The first issue was for me to learn how to sing naturally during the Andante part. She felt that this was particularly important for me at that point. The second issue was to work on the speed of the rondo itself, including such difficult passages as the double notes and arpeggios, and the need to relax the wrist and arm toward the end of the piece. The third issue was how to keep the lightness while maintaining the energy level and atmosphere, and to give the music a convincing shape harmonically.

\section{Rachmaninoff: Prelude in G Minor, Op. 23 no. $5^{72}$}

After having played this piece for the first time, I remember feeling exhausted, although it was just six pages long. Sudiarso taught me that what made me tired was my using so much unnecessary energy to play the piece: "The more you move, the more energy will be wasted--and it is really unnecessary.

The first issue was to differentiate among the staccato, portato, and accent marks. The second issue was to approach playing chord with precision and a huge sound, without becoming harsh or getting tired easily.

\footnotetext{
${ }_{71}^{71}$ learned this piece in 1997 during pre-conservatory level II.

${ }^{72}$ I learned this etude in 1996 during pre-conservatory level I.
} 
She said that big sound was produced from the key and then followed through, not vice versa. If you start with your hand away from the keyboard and then attack the keys, it will create unnecessary hand/body movement and harsh sound. ${ }^{73}$

The third issue was an approach to playing repeated chords, in which each chord must have a different sound, with a direction aimed clearly for the last chord. Regarding the texture, with its heavy chords, there is the danger of losing the overall structure of the music. The fourth issue was to work on the lyrical middle section, to bring out the collaboration among the contrapuntal voices.

\section{Schulz-Evler Concert Arabesque on the "Blue Danube"74}

I was only able to begin this work with Sudiarso, just prior to my move to America. Both technically and musically, this was perhaps the most difficult piece I encountered during my study with Sudiarso. The problem was not just the speed, but also how to let the music dance in the midst of all those challenging figurations. At that time, I did not feel sufficiently ready to play this music; as a result, I played basically just on the surface--most of the notes, but without much understanding. The first issue was to execute the introductory passages, which were extremely difficult, especially for my hand size. She asked me not to focus too much on the right hand, but still hear the main melody in the left hand. The tempo depended on the left hand.

\footnotetext{
${ }^{73}$ Ibid.

${ }^{74}$ I learned this piece in late 1999 during my post pre-conservatory level III
} 


\section{CHAPTER VII \\ “CITRA” AND “HAPPY BIRTHDAY”}

This chapter discusses some of the ways that Sudiarso's students have identified with and responded to her teaching legacy, including composing pieces dedicated to her. In this regard, I will provide analyses of two piano compositions by her former students, Johannes Nugroho and Levi Gunardi; both are well known in Indonesia as composers and concert pianists. Many of Sudiarso's students have been successful in establishing themselves as reputable musicians both in Indonesia and abroad.

Both Nugroho and Gunardi studied under the guidance of Sudiarso while in Yayasan Pendidikan Musik music school. Nugroho completed his pre-conservatory program in 1989 with an "Award for Exceptional Manifestation of Proficient Techniques and Keen Musicianship," while Gunardi graduated from the pre-conservatory program in 1996 with the "YPM Artist Award," the school's most prestigious honor. Both of these artists are leaders among their country's pianists and composers today; their works have been performed within Indonesia and abroad.

Born on May 12, 1970, in Pekalongan, Nugroho earned his Bachelor of Music (1994) and Master of Music (1995) in piano performance at Towson State University, near Baltimore, Maryland. In 2005, he completed his DMA in piano performance from Indiana University at Bloomington. After graduation, Nugroho returned to his homeland, where he currently serves as a piano faculty member at Universitas Pelita Harapan.

Nugroho has been a prizewinner in several piano competitions, including the Aber D. Unger Piano Competition, Sarah Stulman Zierler Piano Competition, Peggy Yale Gordon Piano Competition, Peggy Friedmann Piano Competition, and the Henry Sanborn Piano Competition. 
He also received an "Award for Outstanding Performance" for three consecutive years from Yayasan Pendidikan Musik music school, a "Talent Award" from Towson University, and an honor from the St. Charles International Piano Competition in Chicago, USA.

In 1996, his Kelana Jiwa for soprano and piano was premiered at the UNICEF (United Nations Children's Fund) Gala Concert in Baltimore, Maryland. His choral work Rhapsodi Tanah Sunda received its first performance at the Indonesian Coffee Hour in Bloomington, Indiana, in 2000. With his choral work Indonesia Jaya Selamanya, Nugroho won a composition competition sponsored in 2005 by the Indonesian Department of Culture and Tourism.

Born in Jakarta, Gunardi earned his Bachelor of Music (2000) and Master of Music (2002) in piano performance at Manhattan School of Music. After graduation, Gunardi returned to Indonesia and he currently serves as the Assistant Director of Academic Affairs in Yayasan Pendidikan Musik and as a piano faculty member at Universitas Pelita Harapan and for the Yamaha Master Course Academia Jakarta.

Gunardi was the winner of the 1992 National Yamaha Electone Festival, under Ferdinand Marsa's guidance. He also received the "Most Outstanding Performance Award" at the Southeast Asia Yamaha Electone Festival in Singapore and another "Outstanding Performance Award" at the International Yamaha Electone Festival in Kyoto, Japan.

His piano recitals have earned him a wide reputation. In 1997, he performed in New York City at Steinway Hall and the Donell Library; both recitals were under the direction of the Leschetizky Association. He has given numerous recitals in Jakarta concert halls, such as Gedung Kesenian Jakarta, Erasmus Huis, Goethe Haus, Usmar Ismail Hall, Salihara Theatre; he has also performed at the Esplanade Recital Hall, Singapore. He appeared as soloist with the Twilite Orchestra, conducted by Addie Muljadi Sumaatmadja (respectively among the most 
popular orchestras and conductors in Indonesia), at events such as the celebration of the fiftieth Indonesian Independence Day at Hotel Dharmawangsa, a concert attended by the President and the Vice President of Indonesia at that time, Abdurrahman Wahid and Megawati Soekarnoputri. Other performances include Musicademia concerts in Jakarta, Bandung, Yogyakarta, and Surabaya; a historical concert at Sydney Opera House; Bratislava's Old Slovak Theatre; and the Berlin Konzerthaus.

\section{Nugroho's Citra}

Johannes Nugroho's Citra was completed in 2007 and dedicated to Sudiarso on the occasion of her seventieth birthday. Citra, which literally means "Image," was written to express

Nugroho's admiration for Sudiarso ${ }^{75}$ Preceding the score, Nugroho wrote a note which explains his inspiration in writing this difficult composition. Written in Indonesian language, it follows:

Citra...

dalam alunan nada-nada merdu yang lembut namun tegas, Citra bertutur tentang pancaran abadi aura seorang guru yang sangat istimewa di negeri Indonesia ini, yang tak lain adalah Ibu Iravati M. Sudiarso, atau yang akrab kami sapa dengan panggilan Tante Ira, yang baru saja memasuki tahun ke tujuh puluh perjalanan kehidupannya yang penuh dengan pengabdian dan prestasi.

Dengan kejernihan idealis mengajarmya, tanpa mengenal lelah, beliau menempa satu persatu murid-muridnya untuk menjadi musisi-musisi berkelas yang memiliki ketajaman cita rasa seni tinggi

Sungguh sebuah anugerah yang tak terhingga bagi kami untuk menjalani proses penempaan sulit tersebut selama bertahun-tahun.

Bahkan hingga kini, aura-nya sebagai seorang guru yang tangguh terus mengingatkan kami kepada ajaran-ajarannya yang keras dalam keseriusan untuk mencintai music dengan sepenuh hati dan usaha.

\footnotetext{
${ }^{75}$ Johannes Nugroho: introduction to the piece.
} 
Citra sejati seorang guru dan seorang seni ini akan terus menemani kami semua; dan tentunya akan kami bagikan pula kepada murid-murid kami...

Selamat berulang tahun, tante Ira!

Doa-doa kami agar kiranya Tuhan terus melimpahkan kasih dan rahmatNya serta mengukuhkan langkah tante untuk memasuki tahun baru yang penuh kebahagiaan ini. Amin... ${ }^{76}$

The translation is as follows:

Citra...

over the rhythm of melodious notes that are tender yet bold,

Citra conveys the eternal glow of the aura of a teacher

who is so special in this country of Indonesia, none other but Mrs. Iravati M. Sudiarso, whom we fondly address as Tante Ira, who just recently entered the seventieth year of her life journey which is filled with dedication and achievements.

With her untainted idealism in teaching, vigorously she forges each and every one of her students to become musicians with class and a keen taste for art.

Truly, it is a boundless blessing for us to have undergone this tough process for years.

Even until the present, her aura as a formidable teacher

Keeps reminding us how tough her teaching is, demanding sincerely that we love music with all of our hearts and efforts.

The true Citra [image] of a teacher and her art shall accompany us all forever; and of course we shall share it with our students...

Happy birthday, Tante Ira!

Our prayers to God for you are to ask Him to bestow His Love and Grace abundantly to you, as well as to strengthen your steps, so that your New Year will be filled with happiness.

Amen...

\footnotetext{
${ }^{76}$ Prelude to the score.
} 
The composition is filled with lyricism and beauty that give a placid, uninterrupted exquisiteness of sound throughout; this feeling can be described with such markings as poetic, radiant, elegantemente, dolcissimo, etc. The whole piece is unified thematically, cast in a traditional ternary form (as shown in Fig. 1). Nugroho writes that he used three fundamental compositional techniques in this piece: passacaglia, left hand ostinato and pentatonic scale formations. The main melodic motive that generates the whole piece appears in the first ten measures. This melodic idea consists of three subdivisions: the double-dotted rhythm figuration, eighth-note figuration, and sixteenth-note figuration. The rhythm of the melody keeps growing into thirty-second notes. Although the left hand ostinato is written in pentatonic scales, the harmony generally stays in D-flat major.

As Figure 1 indicates, in Citra we find an overall A-B-A form among the eleven statements of the passacaglia, as delineated by the starting pitches of the left-hand ostinato. In each statement Nugroho exploits different transpositions, in which each level seems to have more and more intensity.

Figure 1. Structural Divisions in Citra

\begin{tabular}{llll} 
Form & Statements & Measure Numbers & Pitches Collection \\
\hline A & $\# 1$ & $1-9$ & C-Db-F-Gb-Ab \\
& $\# 2$ & $10-27$ & Db-F-Gb-Ab-C \\
& & & \\
B & $\# 3$ & $28-39$ & Rising pitches: F-G-Ab-Bb-Cb-Db \\
& $\# 4$ & $40-42$ & E-E\#-F\#-A\#-B \\
& $\# 5$ & $43-45$ & E-F\#-G-B-C \\
& $\# 6$ & $46-51$ & F-G-B-C-E \\
& & & \\
A & $\# 7$ & $52-53$ & C-Db-F-Gb-Ab \\
& $\# 8$ & $54-60$ & E-G\#-A-C\#-D\# \\
& $\# 9$ & $61-78$ & Db-F-G-Ab-C \\
& $\# 10$ & $79-84$ & C\#-D\#-E-G\#-A \\
& $\# 11$ & $85-88$ & Db-F-G-Ab-C
\end{tabular}


The first A section, which consists of the first two of eleven statements, starts at a very soft dynamic level, with specific markings: poetic, radiant, leggierissimo e molto espressivo (light and very expressive), and parlando elegantemente (speech-like and elegant). Although the music indicates D-flat major, the tonality is not immediately clear at the beginning, as there is ambiguity between traditional tonal harmony and other influences, especially that of the pentatonic scale. In the beginning, the left hand begins with the note $\mathrm{C}$; therefore, the function of $\mathrm{C}$ seems to be the leading tone to D-flat in measure 10. Much of the dramatic interest derives from the contrast between the passacaglia statement and the rhythmic motive in the melody, which is indicated con forza (with force). The second statement, now in D-flat major, has more dynamic marking, as indicated piu forte exultante (louder and exultant) and il canto con somma passione (singing with great passion).

Figure 2. The First Passacaglia Statement in the left hand (mm. 1-3). Section A.

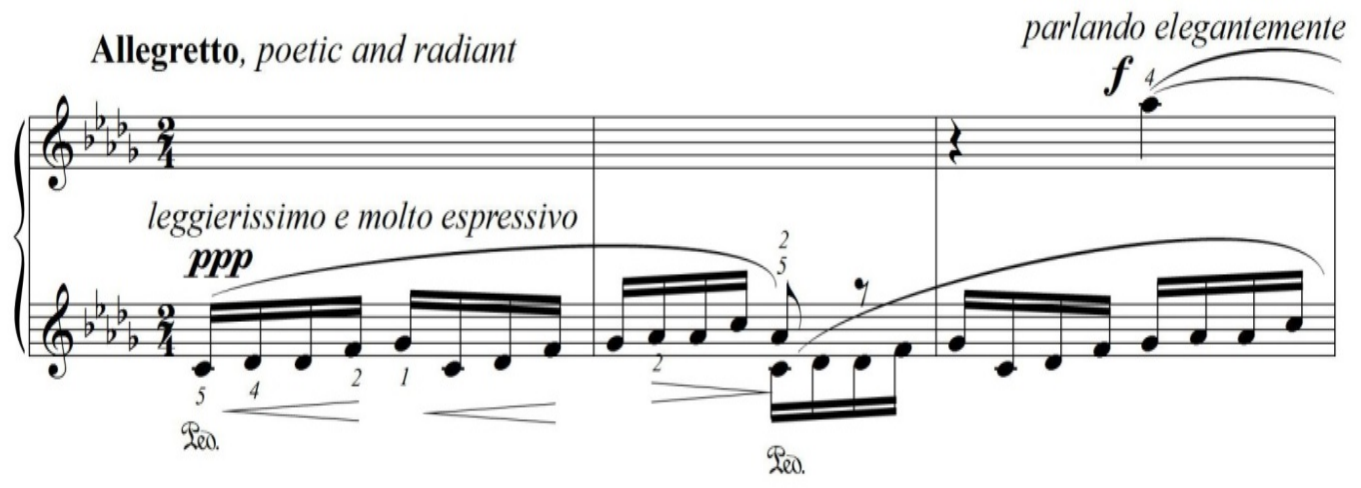


Figure 3. The Second Passacaglia Statement (mm. 10-12). Section A.

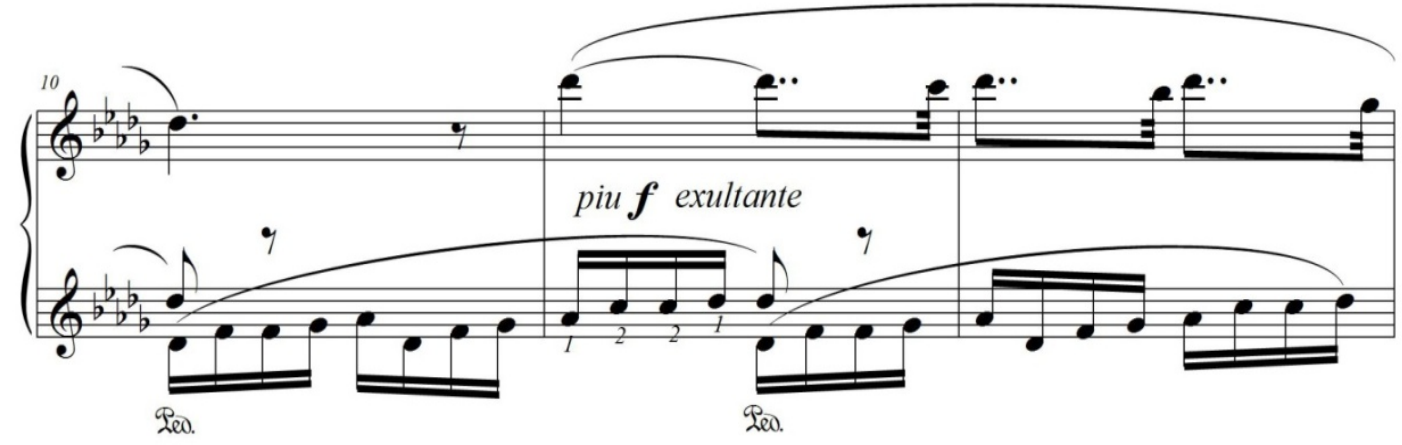

Near the end of the A section another contrast appears, as shown in Fig. 4 with the right hand marked morendo (dying away) and the left hand punctuated by four-note accents in measure 27. The melody now switches register to bass clef with both hands marked cantando poco marcato (singing and a bit marked) in the left hand and marcato e deciso (marked and determined) in the right hand. While Section A reveals two passacaglia statements, we see a total of four passacaglia statements in the B section, beginning at measures $28,40,43$, and 46 , respectively, as shown in Figures 4-7 below.

Figure. 4. The Third Passacaglia Statement (mm. 27-29). Beginning of B Section.

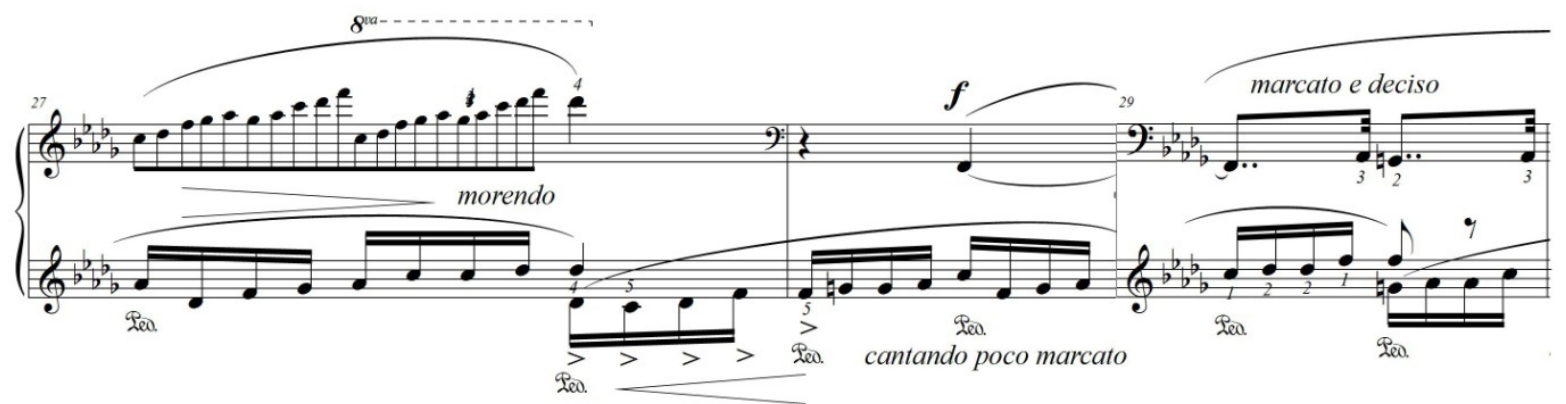


Figure 5. The Fourth Passacaglia Statement (mm. 40-41). Section B.

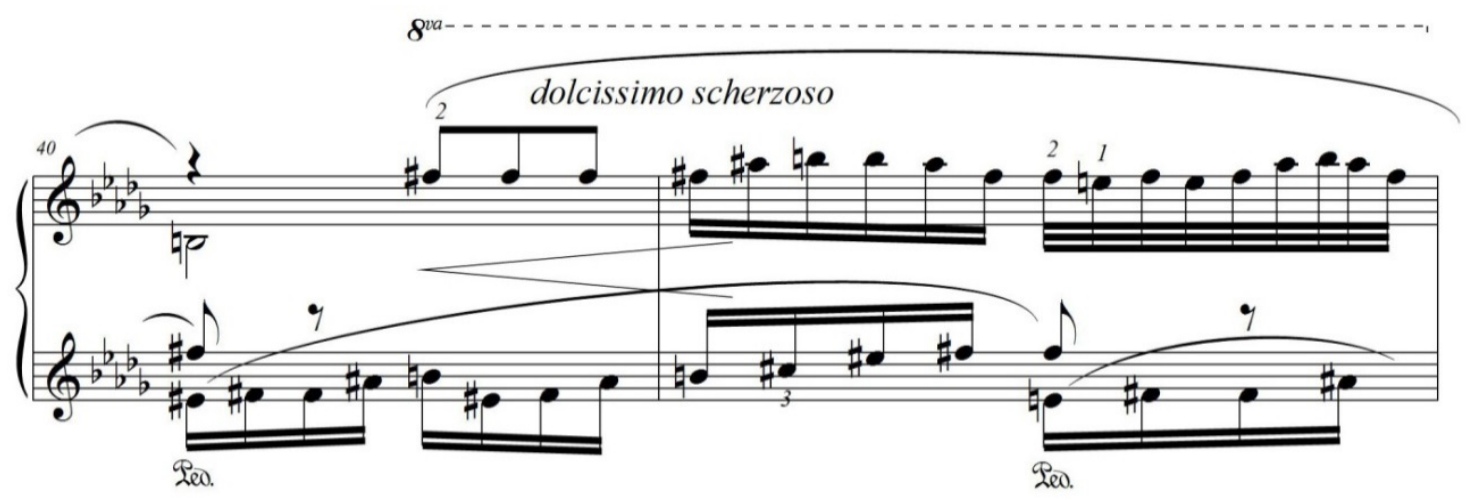

Figure 6. The Fifth Passacaglia Statement (mm. 43-45). Section B.

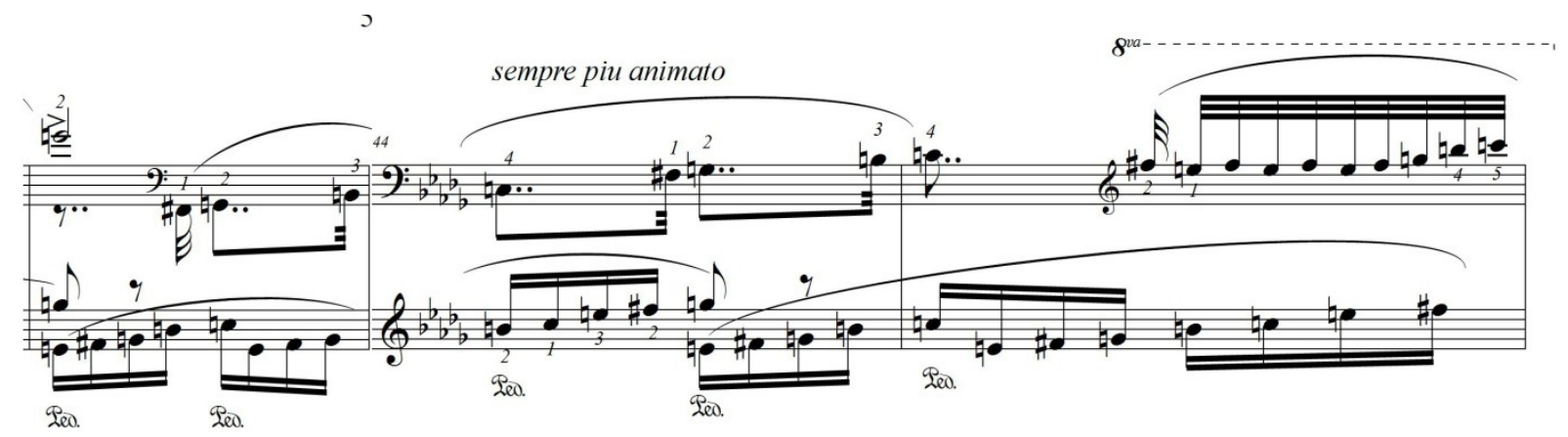

Figure 7. The Sixth Passacaglia Statement (mm. 46-48). Section B.

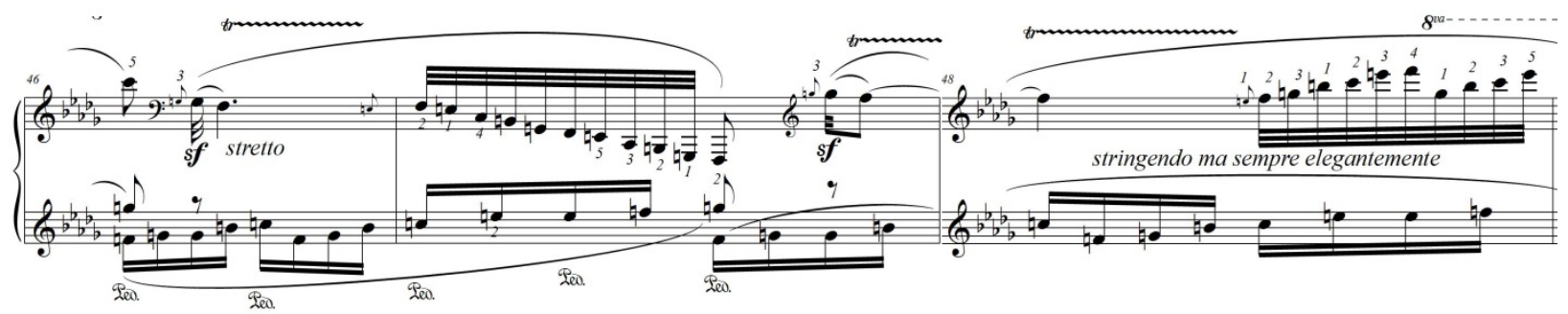

The B section (mm. 28-51) reveals a wide range of characters, including dolcissimo scherzoso (very sweet and humorous), sempre piu animato (more and more animated), stretto (becoming faster), stringendo ma sempre elegantemente (gradually faster but always elegantly). The section also features a series of ascending pitches in the left-hand ostinato figures from 
measures 28-39: F-G-Ab-Bb-Cb-Db. The series of rising pitches leads to poco a poco animato (gradually animated) in measures $37-38$ before the fourth statement enters in measure 40 . The section reaches a climax in measures $48-51$ before being abruptly cut in measure 51 by fermata signs in both hands.

The A section returns in measure 52, preceded by extreme dynamic contrast of forte and pianississimo, perhaps suggesting whispering where the composer indicates tempo primo (beginning tempo) and solemne. There are two interesting features about the return of A section. First, the composer starts the section with the pitch C-sharp instead of D-flat, which is the enharmonic relationship; not until measure 61 does the C-sharp again become D-flat. Second, the section continues to "develop" rather than being a calm reflection on the tonic. In a total of five passacaglia statements in the return of A, the markings vary, including passionato (passionate), many crescendos and decrescendos, stringendo (getting faster), marcatissimo scherzando (very marked and humorous), piumosso e luminoso (with more motion and bright), sempre accelerando (always accelerating), and declamando e pesante (declaiming and heavy). The concluding A section contains the most character contrast of the whole piece; it is also the longest of the three sections. Figures 8-12 show the passacaglia statements of the concluding section A.

Figure 8. The Seventh Passacaglia Statement (mm. 50-53). A Section.

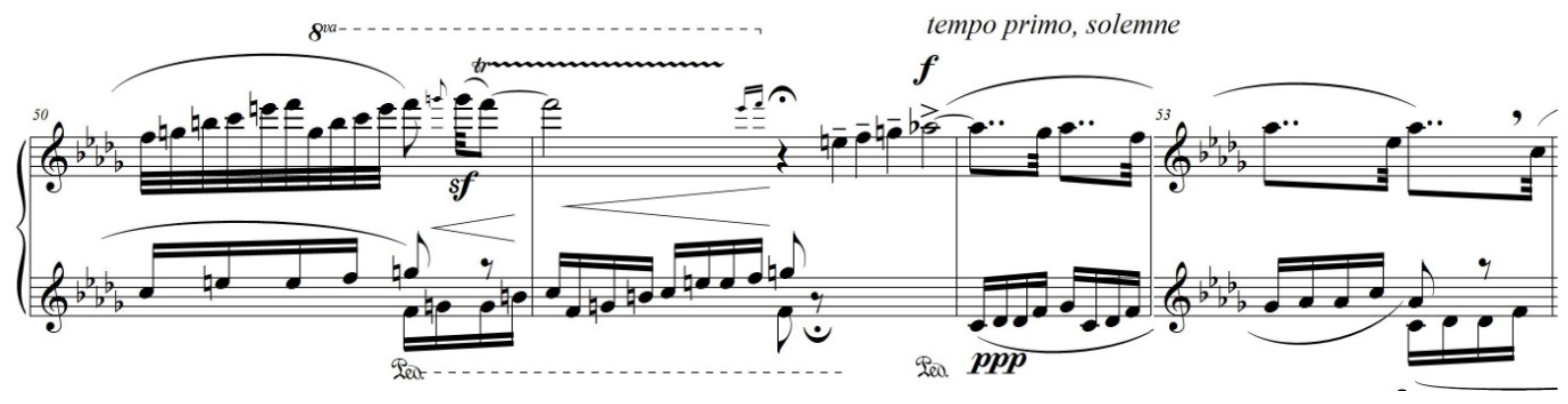


Figure 9. The Eighth Passacaglia Statement (mm. 54-56). A Section.

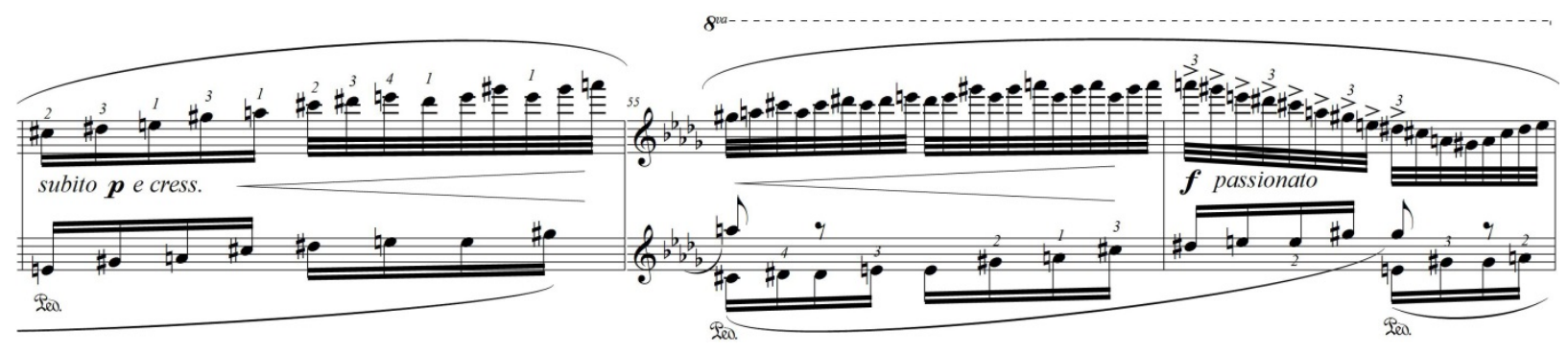

Figure 10. The Ninth Passacaglia Statement (mm. 61-63). A Section.

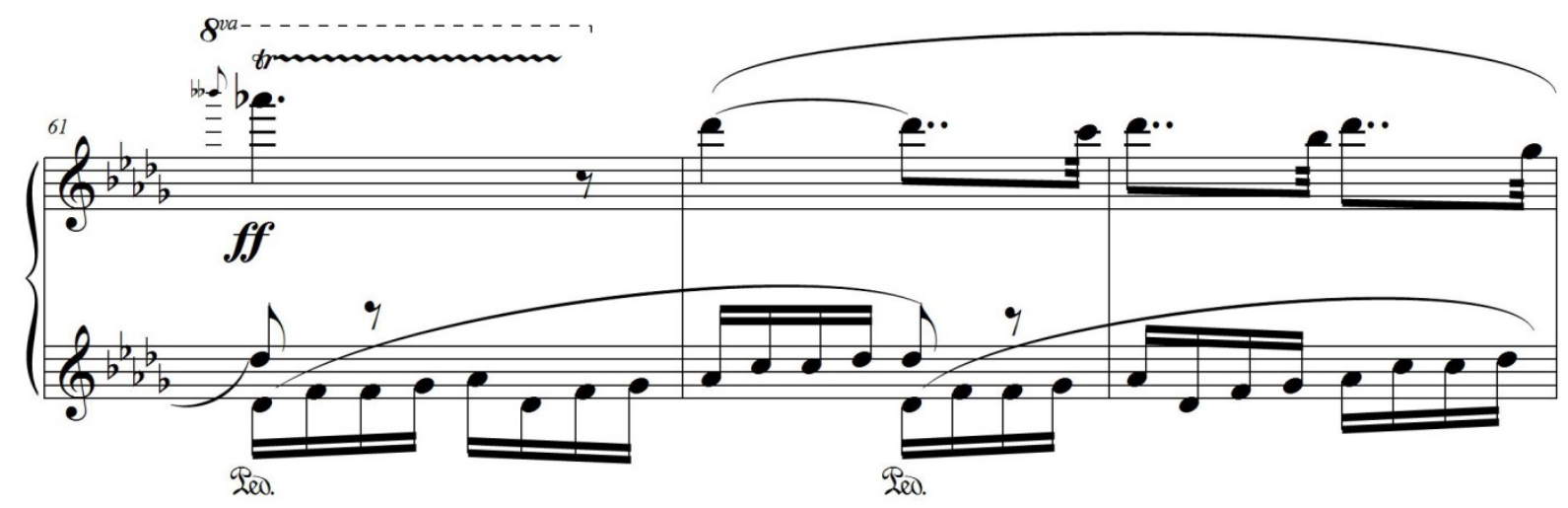

Figure 11. The Tenth Passacaglia Statement (mm. 79-81). A Section.

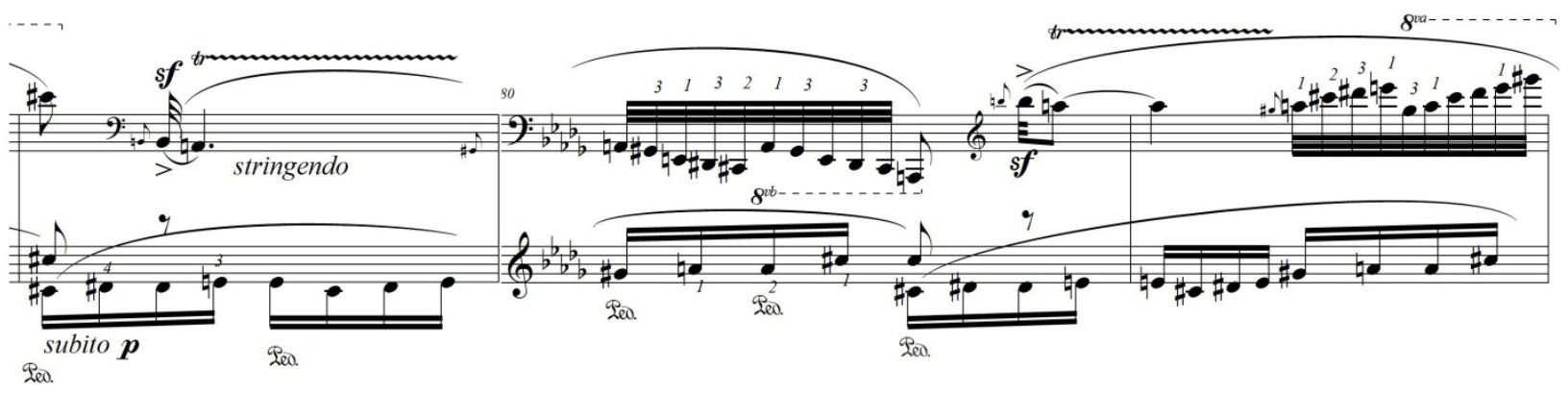


Figure 12. The Last Passacaglia Statement (mm. 85-88). A Section.

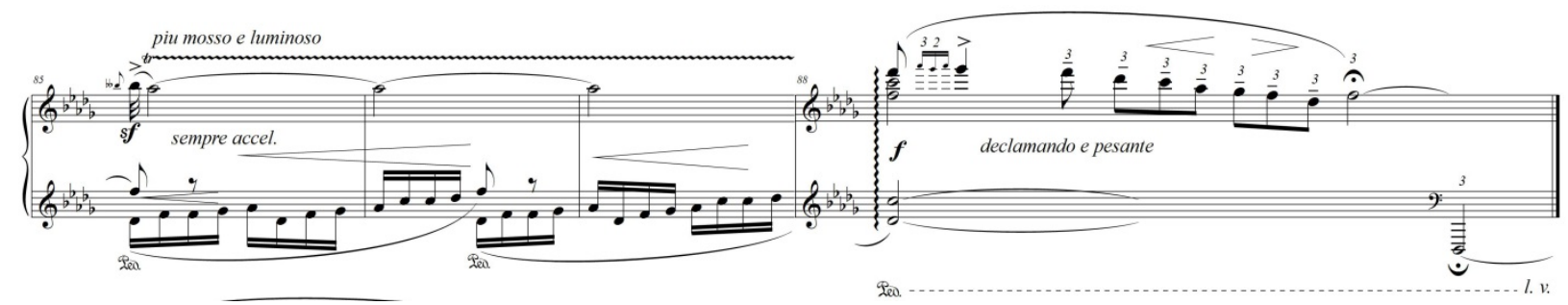

Figure 13. Characters of Each Statement in Citra.

St. \#1 leggierissimo e molto espressivo: very light and very expressive

St. \#2 piu fexultante: more forte exultant

St.\#3 Cantando poco marcato; marcato e deciso: singing with marcato and Decision

St. \#4 dolcissimo scherzoso: very sweet and humorous

St. \#5 sempre piu animato: always more animated

St. \#6 stretto; stringendo ma sempre elegamente: faster; tightening with elegant

St. \#7 tempo prime, solemne: tempo I, solemn

St. \#8 subito p e cresc., passionate: sudden piano and crescendo, passionate

St. \#9 no markings

St. \#10 stringendo, marcatissimo, scherzando: tightening, very marked, humorous

St. \#11 piu mosso e luminoso; declamando e pesante: with faster and bright; declamatory and heavy

\section{Gunardi's Happy Birthday}

Levi Gunardi’s Happy Birthday was completed on September 28, 1995, and it is

dedicated to Sudiarso for her fifty-eighth birthday. The piece was written as a farewell gift when Gunardi completed his pre-conservatory level three ${ }^{77}$ before continuing to Manhattan School of Music. The piece was intentionally written in a very simple style, as it symbolized his ingenuous heart toward her; ${ }^{78}$ it is a freely-composed new piece that is given that title.

\footnotetext{
${ }_{78}^{77}$ Appendix D.

${ }^{78}$ Levi Gunardi, emailed to Mario Santoso, Morgantown, WV, April 10, 2013; analysis is provided in Appendix F.
} 
The composer suggests that it is easier to analyze this music using pop-chord symbols, rather than traditional Roman numerals, since it was written in a semi-classical style. ${ }^{79}$ Although the tonality is clear in $\mathrm{C}$ major, we find almost constant chromaticism, including extended chords, chords of addition, some quintal harmony in the left hand, and slash chords.

As Figure 14 indicates, in Happy Birthday we find an overall five-part form (ABABA), written in a monothematic idea with short introduction. The explanation of sections A and B is based on harmonic relationship (I-IV), in which B is written in melodic sequence. The monothematic idea occurs since both sections are written in the same textural contour. The chord notations include chords of addition (mostly added $\left.9^{\text {th }}\right)$, extended chords $\left(9^{\text {th }}, 11^{\text {th }}\right.$, and $\left.13^{\text {th }}\right)$, and slash chords.

Figure 14. Structural Divisions in Happy Birthday.

$\begin{array}{lll}\text { Introduction } & \mathrm{mm} .1-9 & \text { C major } \\ \text { A } & \mathrm{mm} .10-27 & \text { C major } \\ \text { B } & \mathrm{mm} .28-43 & \text { F major } \\ \text { A } & \mathrm{mm} .44-53 & \text { C major } \\ \text { B } & \mathrm{mm} .54-72 & \text { F major } \\ \text { A } & \mathrm{mm} .72-84 & \text { C major }\end{array}$

After nine measures of introduction, the first A section extends from measures 10 to 27 . The B section starts in measure 28 and is based on a modulating harmonic progression; as mentioned above, the section employs a sequential pattern that is based on the melody derived from A. The following two sections resemble their predecessors, with a slight modification in the second $\mathrm{B}$ section, which reveals a thicker texture and a wider range. The concluding A section, starting from measure 72 , has the texture in both hands moved up to the upper register; marked dolcissimo (very sweet); this final section best illustrates the composer's gratitude towards Sudiarso.

${ }^{79}$ Ibid. 
As Figure 15 illustrates, the piece is clearly in $\mathrm{C}$ major from the beginning. Within a homophonic texture, the left hand features some quintal harmonies and the overall harmonic style is extended beyond the traditional diatonic vocabulary.

Figure 15. Excerpt of the Introduction (mm. 1-3).

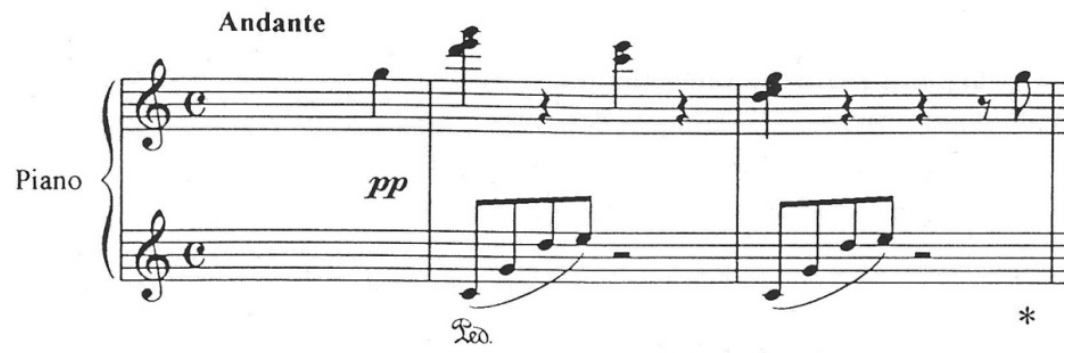

Figure 16 shows the C-major tonality of Section A, which contains two eight-bar phrases in an antecedent-consequent structure. The melodic theme is repeated four times and it is written in a simple homophonic texture.

Figure 16. The Beginning of A (mm. 10-11).

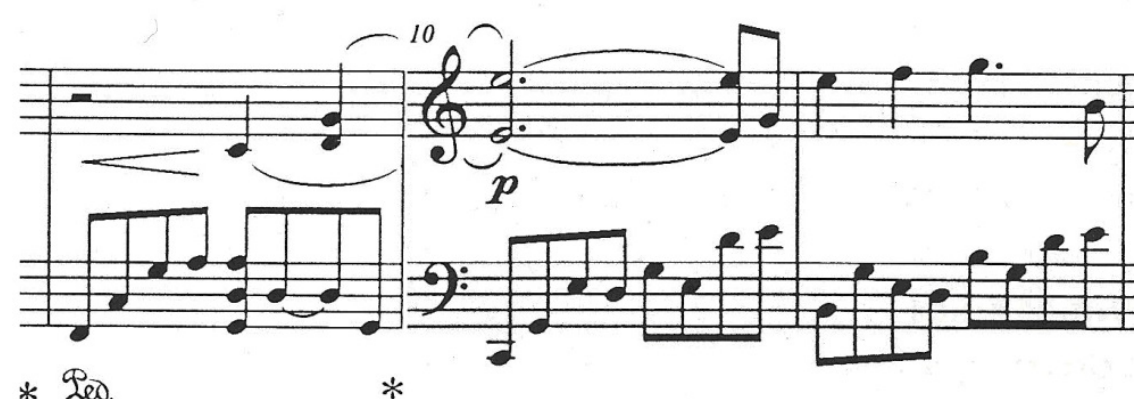

* Ded.

The musical elements of the B section derive from section $\mathrm{A}$; this is especially clear in the left-hand accompaniment and the right-hand melodic contour, as we see in Figure 17. In fact, sequences based on these melodic materials and accompaniment figurations permeate the entire work; this section has three melodies written as sequence in a descending contour. 
Figure 17. The Beginning of $B(\mathrm{~mm}$. 28-30).

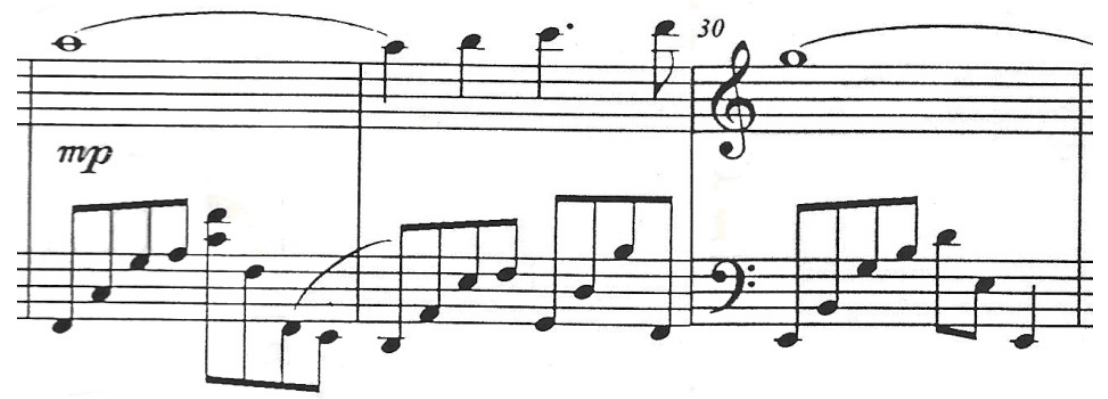

The climax of the piece occurs during the return of the B section, beginning in measure 54 Gunardi indicates pосо а росо animato (gradually getting animated), and he introduces a more chordal texture in the melody, a more active rhythm of thirty-second notes in measure 61 , and a dynamic climax followed by a fermata in measure 71 .

Figure 18. Excerpt of the Climax (mm. 60-62).

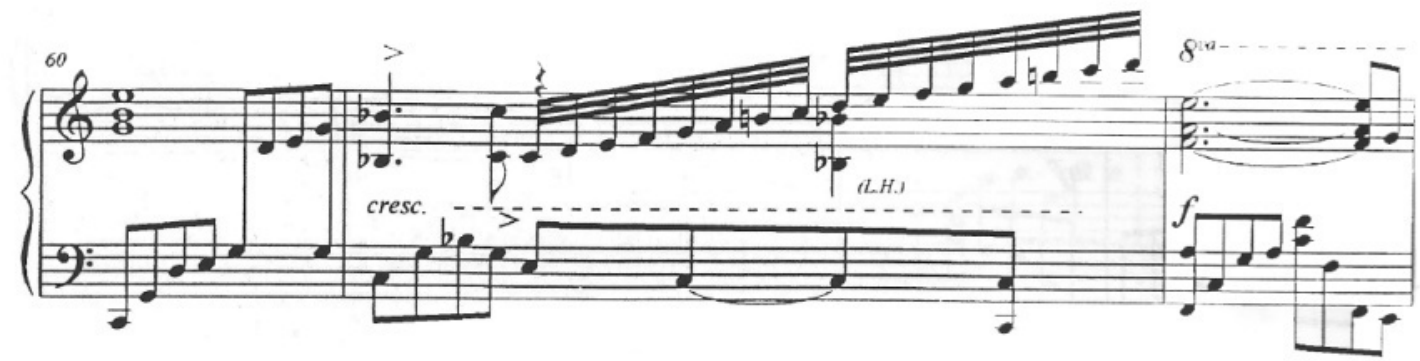

The last A section is presented in the same range with the introduction, indicated pianissimo (very soft) and dolcissimo (very sweet) with much simpler left hand alberti bass-like figuration. The harmony unexpectedly progresses to bVI in measure 81 before resolving back to $\mathrm{C}$ add9 in the last bar. 


\section{CHAPTER VIII CONCLUSION}

Iravati Mangunkusumo Sudiarso is surely one of the most important and respected musical figures in Indonesia. Her teaching and performing have inspired and guided successful generations of pianists for more than forty years. With her professionalism and idealism in teaching, combined with endless dedication, Sudiarso has helped many students to achieve high artistry and taste in piano playing; many of those former students must have established respected positions for themselves in the world of music. Through Sudiarso's own teaching positions, especially at Yayasan Pendidikan Musik, her contributions to younger generations of pianists and teachers are wide; her students' successes serve eloquently to document her teaching legacy.

Teaching music is very important for Sudiarso. Her mother, Hestia, instilled a love for the piano since her earliest years. Sudiarso states, "I have to be an artist because I have to eat spiritually. You die if you don't play. I don't want that to happen to me because then I can't give anything to anybody." 80

Sudiarso's open-mindedness also makes her appreciative of many genres of music, from Western European Classical music to Javanese music to Jazz music. As she explains, "Music cannot be put into boxes. Classical music is related to jazz, jazz is related to pop, and pop is related to so many other things. Good music is good music. ${ }^{\prime 81}$ Her goal in teaching is to refine the students' artistry and taste, along with mastering repertoire by the greatest Classical

\footnotetext{
${ }^{80}$ Tania Budihardjo “Gifted Iravati Has a Heart for Music," The Jakarta Post, http://www.thejakartapost.com/news/2002/09/01/gifted-iravati-has-a-heart-music.html (accessed April 11, 2013).

${ }^{81} \mathrm{lbid}$.
} 
composers. One of the many Western composers that she deeply respects is Wolfgang Amadeus Mozart; she frequently mentions that his music does a lot which is beyond human reach.

Sudiarso's roster of piano students consistently includes those who earn the highest grades from level six of the school's annual examinations. Once they are admitted to her studio, each of these fortunate students can count on getting an extremely high level of instruction, since she is always fully committed to their education. As part of a shared responsibility for these lessons, she requires students to practice slowly, to read the notes correctly, and to know the markings written on the score.

Many of Sudiarso's former students have made important international contributions. Indonesian musicians and scholars should be especially careful to hold her legacy in high regard, because most successful Indonesian musicians of our time will have intersected with her at some point. 


\section{SELECTED ANNOTATED BIBLIOGRAPHY}

Brown, William. Menahem Pressler: Artistry in Piano Teaching. Bloomington: Indiana University Press, 2009.

Presents Pressler's approach to performance and teaching, including technical exercises, principles of relaxation and total body involvement, and images to guide the pianist's creativity toward expressive interpretation. Insights from the author's own lessons, interviews with Pressler, and recollections of more than 100 Pressler students from the past 50 years are gathered in this text. Measure-by-measure lessons on 23 piano masterworks by, among others, Bach, Bartók, Debussy, and Ravel as well as transcriptions of Pressler's fingerings, hand redistributions, practicing guidelines, musical scores, and master class performances are included.

[RILM Accession Number: 2009-00339].

Budihardjo, Tania. "Gifted Iravati Has a Heart for Music.” The Jakarta Post. http://www.thejakartapost.com/news/2002/09/01/gifted-iravati-has-a-heart-music.html (accessed April 11, 2013).

Diruta, Girolamo Il Transilvano (1593, 1609). The Netherlands: Frits Knuf Buren, 1983. [RILM Accession Number: 1988-01797].

Ernst, Sara Marie. “The Legacy of Master Piano Teacher Marvin Blickenstaff: His Pedagogy and Philosophy." PhD diss., University of Oklahoma, 2012.

The legacy of master piano teacher Marvin Blickenstaff (b. 1935) is documented in this study through an analysis of his philosophy and pedagogical style and of his contributions to the field of piano pedagogy. Blickenstaff's extensive career includes teaching piano to all ages for over fifty years, giving presentations to teachers both nationally and internationally since the later 1960s, and publishing writings on teaching and materials for students. His major professional positions have included a professorship at the University of North Carolina at Chapel Hill for ten years (1969-78) and at Goshen College for twenty-one years (1978-99), and presidency of the Board of Trustees of the Frances Clark Center for Keyboard Pedagogy since 2000.

The primary resources for this study were Blickenstaff's publications and presentations, recordings of his piano lessons and classes, interviews, and surveys. The principal investigator conducted six interviews with Blickenstaff and interviewed twenty-two of his colleagues and students. To span the breadth of Blickenstaff's career, thirty-seven additional students and thirty-six teachers were surveyed. The interviews and surveys revealed how Blickenstaff's professional works impacted individuals within the field of piano pedagogy and established his philosophy and teaching style. Twenty-one piano lessons, a small-group lesson, and two classes were observed in 2009 at his home studio in Pennsylvania and at the New School for Music Study in New Jersey. These lessons are excerpted throughout this study to validate and demonstrate the tenets of Blickenstaff's 
philosophy and his pedagogical strategies. Blickenstaff's output as a presenter was analyzed through his presentation notes and through videos of his workshops and master classes. The major publications that Blickenstaff coauthored are the Handbook for Teachers published in conjunction with the Celebration Series, and Music Pathways, a method for beginning pianists. In addition, Blickenstaff's articles in the journal Keyboard Companion were consulted.

The eight chapters of this study document Blickenstaff's career, philosophy, and pedagogical style. In the introductory chapter, the purpose and justification of the study is established. The methodology and research procedures are presented in chapter two along with a summary of related studies. Chapter three contains a biography of Blickenstaff that chronicles his significant professional activities. Blickenstaff's philosophy of music education is outlined and validated in chapters four, five, and six. Chapter four presents Blickenstaff's viewpoint on the definition of music, the teacher, and the student. In chapter five, Blickenstaff's foundations for music study are explored through an analysis of the value of music study and the qualities of the student-teacher relationship. His philosophy on the learning process is detailed in chapter six, which includes an examination of the learning environment and how humans learn. In chapter seven, Blickenstaff's pedagogical style is codified through a summary of his lesson content, teaching techniques, and style of communication. The final chapter addresses the research questions posed in chapter one and synthesizes his philosophy, pedagogical style, and contributions to the field of piano pedagogy into his legacy. The ten appendices include lists of his publications, articles, recordings, and presentations, as well as transcripts of all interviews with Blickenstaff and reproductions of the questionnaires administered to piano teachers and his students [ProQuest Document ID: 1277010364].

Gieseking, Walter, and Karl Leimer. Piano Technique. New York: Dover Publication, Inc., 1938.

Hutton, Judy Foreman. "The Teaching and Artistic Legacy of French-Born Pianist Daniel Ericourt.” DMA diss., The University of North Carolina, 1993.

The principal objective of this study was to investigate the professional career of Frenchborn pianist Daniel Ericourt (born 1903) and, more specifically, to explore Ericourt's contributions as artist-in-residence at The University of North Carolina at Greensboro from 1963 to 1976 . Secondary objectives were to compile biographical data in order to establish Ericourt's educational and professional background, identify important teachers and associates, and disclose events, philosophies and achievements which influenced his artistic development and led to his career as pianist and pedagogue.

The most important source of data was personal interviews with Daniel Ericourt and his wife Jayne Winfield. Other sources of information were interviews with former UNCG colleagues and students, international concert programs, audio recordings, critical reviews, personnel files, books, personal letters, newspaper and professional journal articles, telephone interviews, testimonials, personal records, and a student survey. The credentials that Ericourt brought to UNCG were indeed distinctive. He had received his training at the Paris Conservatoire, from which he graduated in 1920 with the premier 
prix in piano. Throughout his career he had associated with many internationally prominent musicians and was in the enviable position of having known French composer Claude Debussy. He had enjoyed a successful, worldwide concert career for more than thirty years. As a recording artist, he had been ranked with many of the top performers, including Gieseking, Richter, and Casadesus. He was considered to be one of the foremost interpreters of Debussy's piano works. He had held professorships at Cincinnati Conservatory (1926-34) and Peabody Conservatory (1957-63), as well as at Musica en Compostela in Spain (summers 1959-62).

What Ericourt accomplished at UNCG as concert artist and master teacher is recognized by former students, faculty colleagues, and administrators. His contributions toward the improved quality of the music program and the broadened cultural perspective of UNCG are unquestionably evident.

[ProQuest Document ID: 304051567].

Mach, Elyse. Great Pianists Speak for Themselves. Mead, NY: Dodd, 1980.

Contains interviews with Claudio Arrau, Vladimir Ashkenazy, Alfred Brendel, John Browning, Alicia de Larrocha, Misha Dichter, Rudolf Firkusny, Glenn Gould, Vladimir Horowitz, Byron Janis, Lili Kraus, Rosalyn Tureck, and André Watts. The pianists describe their early training, teachers, practice habits, concert routines, and future plans. Some of them also offer their views on repertoire, contemporary music, music critics, stage fright, piano technique, and the requisite qualities of a virtuoso pianist.

[RILM Accession Number: 1980-05096].

Sachs, Janus. "Chopin Sonata." Piano World Home.

http://www.pianoworld.com/forum/ubbthreads.php/topics/585448/Chopin\%20Sonata (accessed April 7, 2013).

Said, Salim. "Sudiarso Duo Concert in Prague.” Petrof. http://www.petrof.com/2008-indonesiekoncert.html (accessed April 8, 2013).

Sandor, Gyogy. On Piano Playing: Motion, Sound, and Expression. New York: G. Schirmer, 1981.

Clarifies concepts of piano playing, describes and organizes fundamental elements of technique, and indicates how to apply these elements in performance. Piano technique is reduced to five basic patterns of motion that form the entire scope of technique. The five are described physiologically, while guidelines for practice and application are given, with illustrations. Also discussed are finger independence and interdependence, evolution and use of pedals, 'singing tone', practicing (including mental practice), memorization, and musical diction (e.g., ornamentation, dynamics, national characteristics). Elements of public performance are analyzed. Live performance criteria are compared with those for recorded performance.

[RILM Accession Number: 1981-05936]. 
Schauffler, Lawrence. Piano Teaching: Math or Science. Chicago: Gamble Hinged Music Company, 1937.

Siagian, Charmaine Blythe. "Selected Solo Piano Works by Contemporary Malaysian and Indonesian Composers from 1979 to 2007: An Introduction." DMA diss., The University of Oklahoma, 2007.

This study provides an introduction to contemporary solo piano works by seven Malaysian and Indonesian composers. The composers from Malaysia are Chong Kee Yong, Ng Chong Lim, Tazul Tajuddin, and Tan Chee-Hwa. The composers from Indonesia are Slamet Abdul Sjukur, Michael Asmara, and Ananda Sukarlan. Seven solo piano works and three solo piano collections are discussed, all of which have been published, recorded, or premiered at a significant event. The pieces vary in difficulty and style, and they range from highly complex ( e.g. Chong's Metamorphosis III) to pedagogical (e.g. Tan's A Child's Garden of Verses ) to avant-garde (e.g. Asmara's A Little Piece for Pianoforte ). Composer biographies represent a significant part of the study. The purpose of the study is to bring attention to contemporary art music for piano by composers from Malaysia and Indonesia that is available to professional performers, students, and teachers for study. Much of this literature has been little known to date and yet is worthy of study. The introduction to the document provides background information on the development of art music in Malaysia and Indonesia including a brief look at the challenges of colonialism as it pertains to art music. The review of related literature includes correlated studies and dissertations, as well as relevant books, articles, and Internet sources that have explored similar study in Indonesia, Malaysia, and worldwide. The discussion of each contemporary work includes comments from the composer obtained through a questionnaire and subsequent interviews and emails. Final chapters provide significant composer perceptions and opinions on the state of contemporary music in the two countries, and include observations from other prominent musicians familiar with the regional scene. The appendices provide an unofficial list of known solo piano works by Malaysian and Indonesian composers, as well as a list of piano works by other composers who have been influenced by the music or culture of the region.

[ProQuest Document Id: 304835478]

SIOK. "Piano Concert Performed by Sudiarso Duo." Slovak Indonesian Chamber of Commerce. http://siok.sk/index.php/en/events/63-piano-concert-performed-by-sudiarso-duo.html (accessed April 11, 2013).

Uszler, Marienne, Stewart Gordon, and Elyse Mach. The Well-Tempered Keyboard Teacher. New York: Schirmer Books, 1991. 
Tamio, Pinkcheer Sintai. "The Interpenetration of Indonesian and Western Elements in Trisutji Djuliati Kamal's 'Sunda Seascapes'.” DMA diss., West Virginia University, 2007. Trisutji Djuliati Kamal ( $b$ Jakarta, 1936) is one of the most prolific of Indonesian composers. Her compositions encompass a wide range of genres including orchestral, chamber, choral, solo piano, opera, ballet, and film music. Due to her childhood musical background, which was dominated by the Javanese musical culture and tradition, combined with her Western musical training in Europe, many of her compositions exhibit the ingenious amalgamation of the musical idioms taken from both traditions. Sunda Seascapes is a set of seven character pieces written for solo piano. Two of the pieces in the set that most strongly exhibit the unique traits of the amalgamation between the two styles are Nuansa Selat Sunda (Nuances of the Sunda Straight) and Misteri Pulau Sanghyang (Mystery of Sanghyang Island). This study provides an analysis and discussion on form, structure, and musical elements that are of Indonesian origin, especially those of the gamelan, and Western musical practices. An analysis of Debussy's Pagodes, a piano composition most frequently cited as being associated with the Javanese gamelan is included.

This document may serve as a resource for musicians and scholars who are interested in studying the works of Trisutji Kamal, and for those who interested in exploring the amalgamation between the Javanese gamelan and Western musical practice. [ProQuest Document ID: 304806935].

Tomassini, Antonio. "Bel Canto: Audiences Love It, but What Is It?" Music. http://www.nytimes.com/2008/11/30/arts/music/30tomm.html?pagewanted=all\&_r=0 (accessed April 7, 2013).

"Iravati M. Sudiarso.”Wikipedia. http://id.wikipedia.org/wiki//ravati_M._Sudiarso (accessed March 28, 2013). 


\title{
APPENDIX A
}

\section{An Article in Kompas, dated 30 June, 1996. "Lebih Jauh dengan Iravati M. Sudiarso"}

\author{
Interviewed and Written by: \\ Rakaryan Sukarjaputra \\ Tony Widiastono \\ Efix Mulyadi \\ Translated by Julian Aaron Widjaja ${ }^{82}$
}

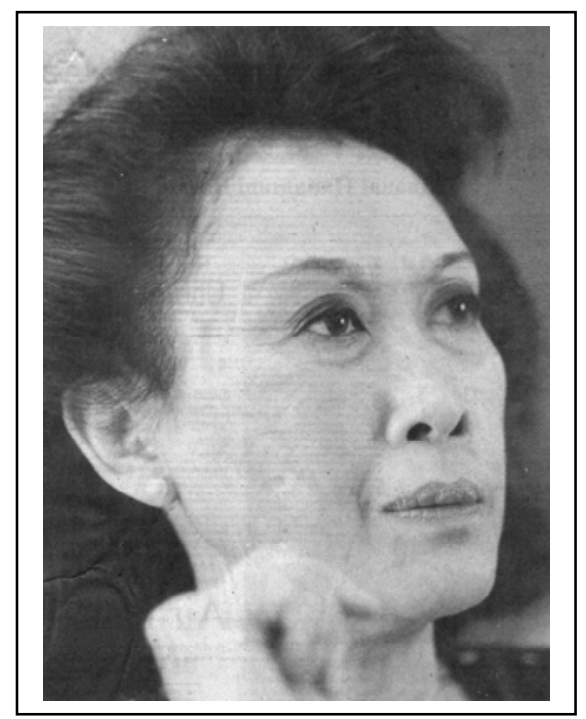

Kompas, Sunday, June 30, 1996

Going Deeper with

\section{Iravati M Sudiarso}

\section{Foreword}

DURING the time when Indonesia aggressively launched their antiAmerican sentiments against anything that can be deemed as "western," she became widely known as a brilliant pianist with international reputations. She did it by performing with the esteemed music group, the New York Philharmonic Orchestra in New York, Unites States. In that country, she also appeared on a variety of musical shows, including television shows, concerts on numerous towns, even in Japan, Australia, and eventually in Indonesia. This doesn't mean that Iravati M. Sudiarso lacks patriotism. She hailed from the family of fighter Mangunkusumo. Her father, Ir. Darmawan Mangunkusumo, was a two-time Minister of Economy during the Sjahrir Cabinet on year 1945 and 1946. Her love towards art developed on her own home during her young age, and she started learning how to play the piano from her own mother, Hestia, a teacher at HIS. Born in Surabaya, September 28, 1937 as the second child of five children, Iravati graduated from a Dutch elementary school on the year 1949 when her father was on duty in that country. While in school at Gymnasium, she continued learning the piano with Mrs. Richard Mayer and melodist Leon Orthel. When she finished high school at Den Haag, she furthered her study at Koninklijke Muziek Conservatorium on the same town. Her music education was continued at the Peabody Conservatory of Music in the United States of America until master level on the year 1962 till 1964. During her time studying at that school, she managed to gain the highest achievement on playing the piano and received the Florence Solomon Award.

She confessed that she is happy, albeit feeling exhausted when she contributed to the growth of art in Jakarta, after the Governor Ali Sadikin encouraged the building of Taman Ismail Marzuki

\footnotetext{
${ }^{82}$ Julian A. Widjaja is a Bachelor graduate of English Literature from Universitas Pelita Harapan, batch 2008.
} 
and all of its equipment. "Jakarta was so passionate during that time, and us artists felt like we got a house, ready to be filled with anything," said her as she reminisce that era during the end of the sixties and the start of the seventies.

She officiated as the Chairman of the Board of Arts in Jakarta twice (1973-1981 and 1986-1989), as well as being the teacher at Lembaga Pendidikan Kesenian Jakarta, now known as the Institut Kesenian Jakarta (1975-1979). Aside from that, she also taught and acted as the Director of academic for Yayasan Pendidikan Musik (YPM), a prestigious music school since 1952 in Jakarta. She also frequently became one of the juries for the Festival Film Indonesia, and several music competitions such as the Festival Guitar Asia Tenggara. Ten years ago, she was awarded with the Medal of Franz Liszt from the Hungarian Government and the Franz Liszt Society. She went on to be married with a banker, Sudiarso S.E. She is blessed with two daughters. The first child is named Anandita Sarasvati (born in 1959), who got married and gave her a grandchild. The young family resided in America. The second child, Aisha Ariadna (born in 1971), is a pianist who recently gained a master degree of music in America, and she pursued a career as an artist in the said country. Ira and Aisha managed to perform together in a piano duet concert in Jakarta on the year 1993, that gained a rave reviews from serious music fans. Decades of being an artist and educator at the same time provided her with all kinds of view regarding the future of Indonesia, which she viewed in a modest manner: If devotion and honesty exist, there is no need to be pessimistic. It can all be started with good education within family.

What makes you intimate with music?

It is because music is a part of our family's daily life. My father owns a huge collection of LP (Vinyl) that includes classical music, even Klenengan, (Javanese Gamelan). They are played every day, like it or not, we listen to them.

Everyone likes classical music?

Everyone, but we are also fond of Javanese music. Our father is also a painting aficionado, and we like them as well. So everything feels complete. We are nurtured with the world of aesthetic. I also like jazz music, but I remember vividly, that it is forbidden to play jazz music on the radio during Sunday. He said that no jazz music is allowed, just the B Minor from Bach, for instance (laugh).

\section{Nurtured into music?}

Maybe not exactly nurtured as in forcing to, but rather to condition us into something positive. After I got older, I realized the benefits of it. When we, us five siblings, were very young, during bedtime, a vinyl will be played. We know which ones are Mozart's and which one are Beethoven's or Haydn's by hearts. Father even created some sort of a quiz, like the one on television back then. We are asked to answer questions like what is the title of the song that is played, who is the composer, and what is the background story behind the conception of it. Of course those made us learn in daytime, like flipping around the vinyl's sleeves or searching for info. 
Strict discipline, was it?

Spartan-like, even. Then again, it was not very rigid either, because there was some playfulness, as well as some off times to avoid boredom. My mother came up with the rule of speaking languages. For instance, Monday is the time for speaking in Bahasa Indonesia, Tuesday is for speaking in Dutch, Wednesday is for German, Thursday is the time for Javanese since the night before Friday is a very crucial day for Javanese people, and then Friday is for French. It went on and on like that. If we speak in different language than the assigned one, it would not yield any responses nor replied. Therefore, it is a necessity to learn, like asking for a drink, for instance, we need to know the name of the drink. It is also applied with the kind of food that we want.

So the languages are complete?

Basically, I am fond of it. Moreover, at Gymnasium in Netherland, I received the subjects of Latin and Greek language every day. So, everything that is conditioned at home is always useful.

Do you have a piano at your home?

It is from my mother who worked as a teacher at HIS in Muntilan, Central Java. Mother saved her salaries in order to buy the used piano. My fingers were too short during that time, but I was able to imitate the song "Bengawan Solo," to the point that my parents believed I might be a genius. Maybe not exactly genius, that will make me an arrogant person, but my ears are indeed very perceptive. My mother taught me how to press the keys, and when I was 5 years old, I received a piano lesson. When our family decided to move to Netherland, I continued studying music. Turns out, the piano from my mother is the one that became my basic start.

When was the time you decided to choose music?

When? Since I was a child. It's kind of difficult to remember when exactly, but I think when I was thirteen years old, I believe that music is the path of my life. Well this is of course, a sentence that I made after I am an adult ..., but well, more or less, that is the gist of it ..., I decided to choose music. There is also a childish consideration, which other subjects seem hard to digest, but if it is music, I instantly became voracious.

Does the strict discipline help you learn music?

I am sure, yes. The term for it nowadays is that since early ages, we are being trained. Indeed, we became strong as the result. My sister, for instance, loves music, but she chose not to become professional and she is willing to carry around her own chair to get in line to buy tickets for her favorite concerts, even though it was during the cold winter. So we developed perseverance.

Does it happen to you as well?

You could say that. When I decided to enroll in music study, I already have a strong determination to get made. I enrolled to Koninklijke Muziek Conservatorium in Den Haag (Netherland, 1955-1958) and received an award. Even after I got married and have a child, I kept on pursuing music; by going to school, and obviously there is a high-price to pay. To me, music has a very strong allure. 


\section{What makes it high-priced?}

Well, I am forced to be separated from my family, with my child who was at her cutest moment; she was only two years old at that time. It was very difficult. The story was that when I returned home to Jakarta, I got offered with Fulbright scholarship to study in America. I was hesitant, but then I got threatened that if I won't take it, it will be granted to a pianist from Korea. My sense of patriotism awoke. As an Indonesian, I have to take this opportunity. I consulted this with my husband. My husband asked me whether going back to school will make me happy or not, and I responded it with a yes. So, I set forth. It was fortunate that my mother is always there to help taking care of Dita, the oldest child.

Did it interfere with your process of studying?

I told you that it was very difficult. But perhaps, it was the strength from the hard training from my family back then, I became resilient. It is said that the Peabody Conservatory of Music in America where I've studied is amazing, but I was lucky. I've managed to gain the Bachelor degree that can take up to four years in one year only. Master degree that takes two years, I gained it in one year as well. In the end, I always gun it down ...

So it is a story of your success

That is correct, but as I have said before, the price that I have to pay is not cheap. When I returned home, my own child did not recognize me no more. It was a heavy blow for me. When I left her she was two years old, when I met her again she was six years old, and when I want to hug her, she refused. It is a mind-blowing thing for a mother.

\section{What did you do about it?}

I did commit something that a mother should not have done so during that time. I did not approach it with the correct manner immediately. Instead, I drowned myself working as an artist, going on stage everywhere, or managing artistic activities, or teaching. I regret it later on. When she reached adulthood, she stated that her heart is broken because her mother was heartless enough to abandon her. Had that time I decreased my activities as an artist and coddle her, it might be a very different story. That experience is what drives me to become a better mother. I often took my second child to my workplaces. When I worked in an office at TIM, when I acted as the head of $D K J$, or when I teach at $L P K J(I K J)$, as well as at YPM, she can visit me whenever she want to, agar so she knows what her mother is doing outside.

You became a great pianist

That's what people said.

You became the first pianist in whole Asia who has performed with the New York Philharmonic Orchestra?

Yes, but there is a fluke factor behind that story. So, there is no need to exaggerate it. I was still going to school at that time in the United States of America, on the year of 1963 if I am not mistaken. For five straight weeks, I performed as a soloist with the New York Philharmonic Orchestra, building an art center, the Lincoln Centre (for the Performing Arts) in New York. 
Perhaps, people remember me due to my Asian heritage. At that time, an Asian playing the piano is still viewed as something bizarre.

What is the meaning of music to you?

Dry. Life would be dry without music.

So you keep on playing?

Constantly. Painters will keep on painting. If not, their skill will get rusty. It applies to me as well. As a pianist, yes, daily training is a must. That's what professional pianist does everywhere in the world. Schurra Cherkasky is still a maestro even tough he is 80 years old. I will keep on playing music no matter what.

But you did stop playing before.

Yes, as a performing artist, when I have to be an art bureaucrat for Dewan Kesenian Jakarta. As a professional artist, it felt like such a waste, but I accepted the job because I believe that art must managed by artists. Someone must make a sacrifice for it.

How does it feel to do a duet with your own daughter?

The concert with Aisha on the year 1993? Thrilled. Extremely thrilled. At first, I felt awkward, because it is quite a challenge. Our age-gap is quite huge; we belong in different and distance generations. But I was overjoyed. Now Aisha is pursuing a career as a professional artist in America. Her first job was acting as the artistic director of a choir group. She felt challenged.

Does age factor help contribute to maturity as a pianist?

Very likely so. I have learned that, views, preferences, choices, becomes different overtime. For example, with my own children, or with other younger musicians. Regarding chosen compositions that we play, it is obvious that the younger one will choose the more passionate compositions that are filled with dreams. Veteran pianist will choose other compositions, perhaps something that projects more depths in its impression.

Back then we have Iravati Sudiarso, is there any more musician with international reputation nowadays?

Yes, there is. Eduardus Halim from Bandung. A renowned pianist named Vladimir Horowitz, who passed away already, once stated that generally speaking, Asian people are only good at imitating. But he confessed that he is 'cured' of this stereotypical view thanks to the existence of Eduardus Halim. The world will be surprised, that someone like him existed in this century. I am so proud when I read about it. Last year, he came here and played a gig. He graduated from Juilliard and he is still in New York. He convinced me that he is still Indonesian, complete with Indonesian passport. His Sunda is also fluent. Internationally speaking, he is deemed as the top one from Indonesia's younger generation. 
How about the younger ones?

Oo... There are a lot. There is Ines Irawati from Surabaya, who joined JOC Yamaha, then applied to America and got accepted, and deemed as a great talent.

So you are not pessimistic?

No. We have countless good talents and among them are hugely talented. The one thing that caused pessimisms is when they fall into the wrong hands that would not mold them as strong characters. That is what caused me to remain passionate for being a teacher, aside as being a musician. If there is love and honesty, there is no need to be pessimistic.

What's going on with music education for the past 25 years?

There is an intriguing development going on. In the past, Jakarta only has YPM, but when Yamaha came along, music course becomes a necessity. The amount of students is abundant. What we need to focus on is the quality, and in all honesty, for it to be enforced will be fairly difficult. So for the past 25 years, the process of trials and errors are conducted all across Indonesia regarding music education. Even the weird ones exist.

What do you mean by "weird"?

For example, they want organ, even in rural areas, buying an organ is mandatory. What for? In my opinion, just take what is readily available, be it guitar, small violin, or gamelan. Everything can be utilized as a medium to teach music. All that remains is the motive of the courses or music school managers. If they are motivated to use their students as moneymaking objects, there is little hope for proper education quality.

\section{What about YPM?}

Yes, we work with certain idealisms, although we still charging school fees. We view the students as education subjects. YPM has two missions. The first one is to provide the opportunity for children to have a hobby; this chapter is the biggest one, because as a teacher, she brings out the love towards music. After that there are some children with extraordinary talents whom all start because of hobby, but then they start to ascend. They will be segregated from others and put into the special course, conservatorium, where they must decide, whether they want to continue or stop right there. Among these, the professional ones, we also gather human resources whom we deemed as skillful with children, as well as having genuine concern towards education and the betterment of their pupils. We do not have the traditional process of "applying as teacher." We are the one who chose, she said - this is crucial, because they must deal with students and the future result of them.

Who are the alumni who make YPM proud?

One of them is Idris Sardi, he was an alumnus of us. He is able to find life-satisfaction from music as well as making a living out of it. Marusya Nainggolan was one of us as well. So did Yazeed Jamin, Dr. Kuei Pin Yeo who now has his own music school, Yayasan Musik Jakarta. The younger one is Aisha. Another one worth mentioning is Mariama Jiwa Jeni. There is also one who have made to the top by himself, whose name is Yahya Ling, now he is the conductor of Cleveland Orchestra, one out of five of the biggest orchestra in United States of America. 
Who is the one who is funding YPM?

We are all able to manage on our own. We are content with our own funding, no other fund from others, and everything is great the way it is since ever. Actually, when Bung Karno takes part on building this, we don't have anything at all, because during that time Indonesia just got its independence. My father took part on building this with the money from a Dutch person who gave it to him. Here is some money, you like art, don't you? Please use it. So then he built this. Since then, the department of Education and Culture once granted their sponsorship. But then, it is really difficult to grant us subsidy, so we decided that it is not needed. We will work for it by all means; teachers are paid with rice. There is no such thing as money. All that we can give are rice and oil. That happened in the sixties.

Is the teachers' salary enough?

I cannot answer it with certainty. But nearly all of us have cars. Meaning, we all can live; we are able to save money. They are all full-timers. Working in while taking classes is also a possibility. By all means, it is a must. To finished college and be graduated. We will help. So, for some of the teachers who are teaching while still studying, they will not be given with too much students to handle, so they can finish their study. If their study remains unfinished, it can lead to frustration in their music as well.

For professional musicians, how are they able to live?

That's a different matter. It is indeed ironic. Someone as great as Suka Hardjana is underappreciated in Indonesia, meaning that is extremely difficult to build a forum to have him perform, and we have not even thought about more deserving income that he deserved.

Is serious music still elitist in nature?

Actually, nowadays, opportunities are wide open. We have art universities. We have radio. We have television. All we need is our own determination, on what we should do; television has such powerful influence. Do not forget, our level of prosperity keep on rising. Rich people are plentiful, but those who are willing to spare some of their excess to fund serious music are still very rare.

Will you remain optimist?

I will, that is why I keep on teaching. That is why we defend YPM, we defend IKJ and other art schools, and let people open as much music courses as possible, providing they have quality. I will remain optimist as long as parents have more times for their children, to expose them with the beauty of art and let them think on their own. I have bitter and sweet memories with my children, and my students, and I would like to infect that to You.

Interviewer: 


\title{
APPENDIX B
}

\section{An Article in The Jakarta Post, dated 1 September, 2002. “Gifted Iravati has a heart for music"}

\author{
Written by: \\ Tania Budihardjo
}

Meeting Iravati M. Sudiarso, one of Indonesia's most respected musical figures and the director of academic affairs at Yayasan Pendidikan Musik (YPM), was a moment to remember.

I am in the auditorium of the Paramount restaurant at one of YPM's numerous Golden Concerts, which are held to commemorate its 50th anniversary, trying to catch up with the understandably busy Iravati.

She is a tiny, dignified lady wearing a traditional outfit in red with a fashionable "'peasant"" pattern, although I doubt that she was intending to be hip. From the back her bouffant hairstyle almost looks as if it was borrowed from the 1960s. Her thickly painted face combined with her outfit lends her the appearance of a China doll.

But no matter what she looks like, I would have still been in awe because I and countless others know what those fingers of hers can do.

As it is slightly past dinner time, the audience animatedly flocks toward the buffet tables on the other side of the room. Iravati invites me to join them.

About a half hour later, Iravati and I are sitting at a plain table on the more deserted side of the room. As she is the biggest notable at the event, Iravati is ironically the last to begin eating.

"I can't eat around big crowds," she said, an interesting confession coming from someone whose career constantly puts her in contact with a lot of people.

As I learn later, Iravati is surprising in a number of ways. She is prestigious but down-to-earth, worldly wise but sensitive. Her manner is somewhat reserved, but her words are full of remarkable passion. Although she speaks with a self-assured poise cultivated from years of fame, she is anything but artificial. Iravati is not trying to fulfill any preconceived notions about herself.

In between her mouthfuls of rice, and with an admirable effort to articulate herself in English, Iravati gave me a glimpse of the personality behind the personage.

"In my career, everything is a challenge," said the musical magnate. Beginning piano lessons at age five with her mother, Iravati probably was reading music before written words. "She instilled in me a love for the piano," said Iravati. 
She went on to study under composer Leon Orthel in 1955 at The Hague Royal Conservatory of Music. After graduating with a prize for Interpretation, Iravati continued her studies at the Peabody Conservatory of Music in the U.S. In that same year, she performed as a soloist with the New York Philharmonic Orchestra to inaugurate the new Lincoln Center for the Performing Arts.

With her schooling finished, Iravati chose to devote her life to teaching and performing in Indonesia. She won a number of awards, including cultural awards from Australia and Japan. She led an ASEAN International Youth Music workshop all over Southeast Asia. In 1988, Iravati was appointed as the director of academic affairs at YPM, a position she continues to maintain.

Known for her expressive renditions of classics, even Iravati's simple English cannot hide her astonishing passion for music.

"I have to be an artist because I have to eat spiritually. You die if you don't play. I don't want that to happen to me because then I can't give anything to anybody." She paused to work on her dinner, giving me time to feel a jolt of amazement and wonder if the church would make her a patron saint of music. And I had spoken to this woman for less than 10 minutes.

"Mozart is a sublime example of something beyond human reach," she said, after struggling to describe her profound feelings. "Everybody talks about Mozart but I don't think half of them really understands what his music is about. His music does a lot," she added emotionally.

Iravati's tendency to describe music in deeply spiritual terms seems to especially extend to Russian music. "When I went to Russia, I discovered this: Even though they have to be Communists by their ideology, they have never been Communists. Their music tells me that it's from God. Russian music is a very special, a spiritual way of expression."

Although I have never heard Iravati play, her words are positive proof that the reports of her famously expressive way of playing are true. This deep connection to music also translates into Iravati's love for teaching.

"I want to create persons. I don't want everyone to play the piano like a machine."

Iravati's open-mindedness also makes her appreciative of many genres of music. In 1979, for instance, she was made an honorary member of the cultural society in Korea. As Iravati reasoned: "Music cannot be put into boxes. Classical music is related to jazz, jazz is related to pop, pop is related to so many other things. Good music is good music."

At this point, I anticipated the question all you cultural sophisticates are thinking: What does Iravati think of Britney Spears? "A gift from God's hand. She's not just beautiful. Something like that happens only once in so many years."

Yes, that one raised my eyebrows, too. 
An open-minded, expressive, immensely passionate pianist -- could Indonesia be any luckier? Yes, it could -- they could have another gifted talent: Iravati's daughter, Aisha.

"I found out that we have the same ideas, we have the same vision and we have the same goals. Then I discovered that we are from the same wood," said the happy mother.

As we walk toward the exit, Iravati takes the time to politely thank the busboys with a kind smile.

As we approach the door a waiter graciously offers Iravati the large, lovely vase of flowers by the door. One of Iravati's coworkers carries the vase out for her, but when we reach her car, Iravati turns and gives them to me. I thank her profusely.

With a vase of flowers from her in my backseat, I ride home feeling very special. 


\section{APPENDIX C}

\section{SELECTED TESTIMONIALS BY INDONESIAN MUSICIANS}

Addie Muljadi Sumaatmadja (March 28, 2013)

Although I have never studied directly with Mrs. Iravati, I always learn something from our discussions. Since the inauguration of Twilite Orchestra, she has always been a mentor for me. She always supports the orchestra. Perhaps our best memory is of when she performed Rachmaninoff Piano Concerto no. 2. Through Yayasan Pendidikan Musik, Mrs. Iravati has made extraordinary contributions and has dedicated her life to the development of music in Indonesia. Bravissima, Ibu Iravati!"

Susiana Aditjhan (April 4, 2013)

"Sudiarso is a disciplined, hardworking, and highly dedicated teacher - all for our better purposes."

Levi Gunardi (April 5, 2013)

"Sudiarso is a teacher who never stops teaching or conveying the love of music to her students. She also teaches her students how to appreciate and respect the music that they learn, both the composer and the music itself. She also instills a sense of discipline within her students, especially in working on their pieces patiently and specifically. Sudiarso also teaches the importance of being humble in sharing music."

Laksmi Soedibjo (April 5, 2013)

"When I came to the first lesson with Sudiarso, I immediately felt such a huge transformation not only in music but also in my character. There were ups and down, but they gave me experience to be more open-minded; it was difficult at first, but I believe that these challenges had a positive impact on me and my values. What I learned the most from Sudiarso is that I need to work very hard with discipline and not give up in learning. To have talent is good, but hard work is much more important; with no hard work, talent means nothing. I have held this concept and shared it with all my students."

Johannes Nugroho (April 6, 2013)

"She is very strict with her students regarding their obligations for artistic responsibility. Thus, she emphasized strongly to her students that this piano study is a very serious endeavor that must demand and absorb the totality of one's being. To me personally, this is her greatest legacy. This is what makes her successful and more than just a mere piano teacher-she is someone who will transform her students to have the right perspective and attitude regarding the art in music. From here, true and sincere appreciation of this beautiful art will open the gate of exploration, so that we can discover both the potential within and the wealth of the field outside." 
Eddy Sutanto (April 7, 2013)

"Iravati Sudiarso is a perfect figure in two regards, as a pianist and as a teacher. As a pianist, she has tremendous knowledge and skills, yet remains humble. As a teacher, she is firm, disciplined, highly dedicated to her profession, and a humanistic figure."

Sudirman Leman (April 7, 2013)

"She is indeed one of the pioneers and important figures in Indonesian musical education. Her firm personality and vision regarding education truly gives inspiration not only to the next generation but also to her colleagues. Although some of her decisions are rather controversial, she will always be consistent with her mission. Her commitment and integrity are something special that is rare in Indonesia."

Delima Simamora (July 9, 2013)

"Iravati Sudiarso is an important music icon in Indonesia, especially in the field of piano playing and teaching. I always admire her performances, which are consistently clear, with such energy that she keeps the audience in awe. Soul, energy, and accuracy, combined with very strong technique, can be observed in all her playing."

Erick Hidayat (July 10, 2013)

"Before anyone else really did so in Indonesia, Sudiarso set a very strict quality control that has defined generations of pianists. Her calling for dedication has also shaped YPM into what it is today."

Alfred Situmorang (July 10, 2013)

"Sudiarso has the highest idealism in music that automatically ensures the highest quality of a performance. Her personally inspirational story regarding her meeting with Arthur Rubinstein and Maria Callas while in Europe emphasizes the importance of simplicity in music, which is possibly the hardest thing to do."

Ivana Tjandra (July 10, 2013)

"Tante Ira always taught with passion. She brought the real music world to me through her past experiences in theater, politics, stage performance and competitions. She often talked about her life as a way to help me understand the bigger picture--not just anything related to piano playing, but also the history and gossip stories behind the music or performance practice. She was very generous with her time and knowledge. She described and demonstrated in every way she could to help me understand better ways to play. She never compromised regarding quality of playing. Through her piano studio, she built a good and healthy culture of friendship in music and at the same time also healthy competition among students as a motivation always to move forward, recognizing each other's strength and weaknesses and helping each other to be better." 


\title{
APPENDIX D
}

\section{Yayasan Pendidikan Musik Music School}

\author{
Academic System \\ Pre - Elementary \\ Elementary \\ Level I - VI \\ Pre-Conservatory I - III \\ Teacher's Diploma Program (Piano and Theory)
}

\author{
Address \\ J1. Manggarai Utara V no. 2 \\ Jakarta, 12850 \\ Tel. 021-8292469 \\ Fax 021-8312009 \\ J1. Kepodang Raya no. 30 \\ Sektor II, Bintaro Jaya \\ Tangerang 15412 \\ Tel. 021-7350374/58 \\ Fax 021-7370470
}

Email: $\underline{\text { sm_ypm@yahoo.com }}$

Leadership

School's Director: Iravati M. Sudiarso

Academic Director: Aisha Ariadna Pletscher

Financial Director: Inge Karjadi

Administrative Director: Oliver Pletscher

Acting Personnel Director: Surtikaryani Muktidarmi

Theory Coordinator: Dyah Nurul Maliki

Assistant Academic Director: Levi Gunardi 


\section{APPENDIX E \\ Johannes Nugroho's Citra}

persembahan kepada Ibu Iravati M. Sudiarso

\section{Citra}
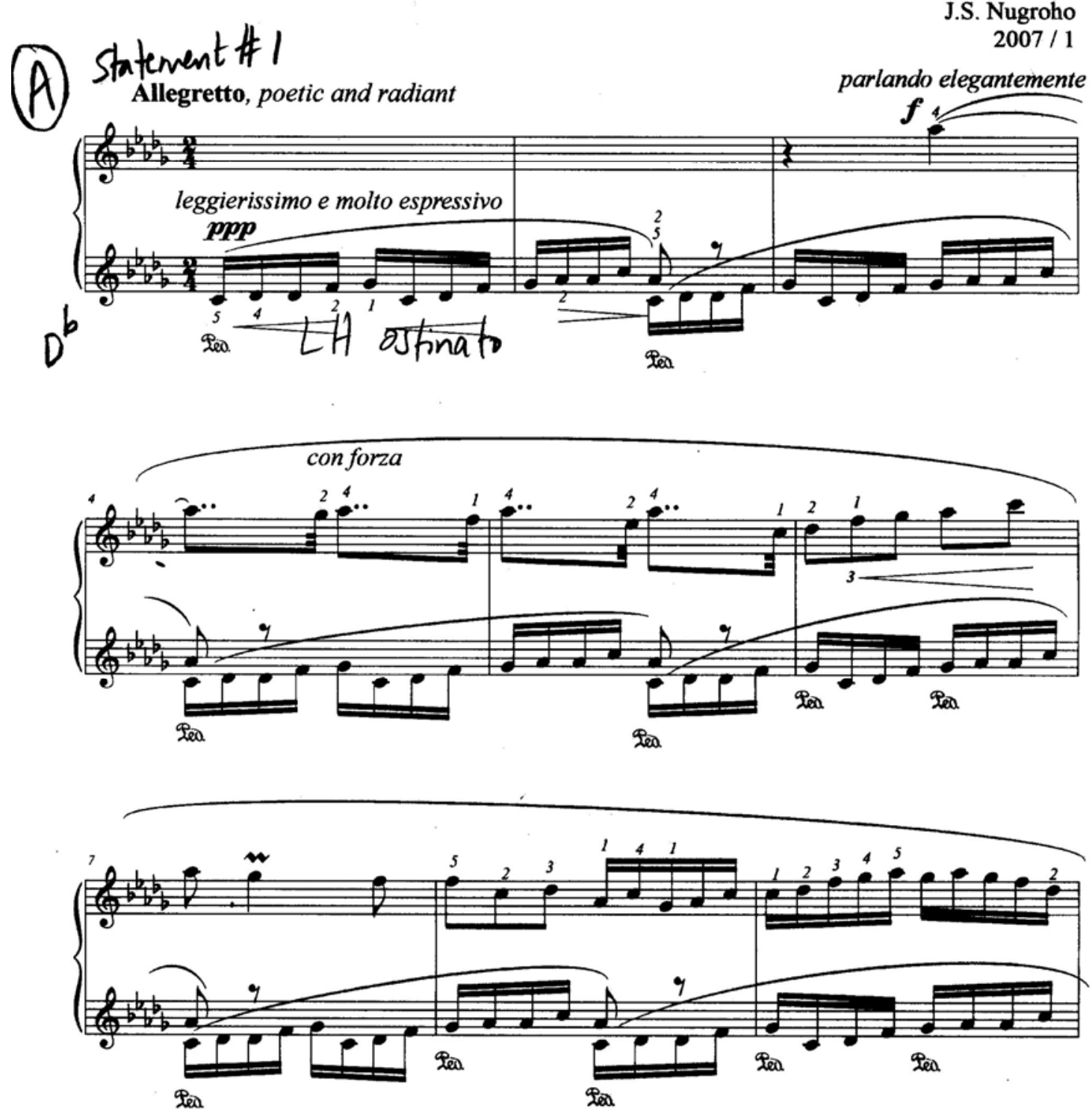

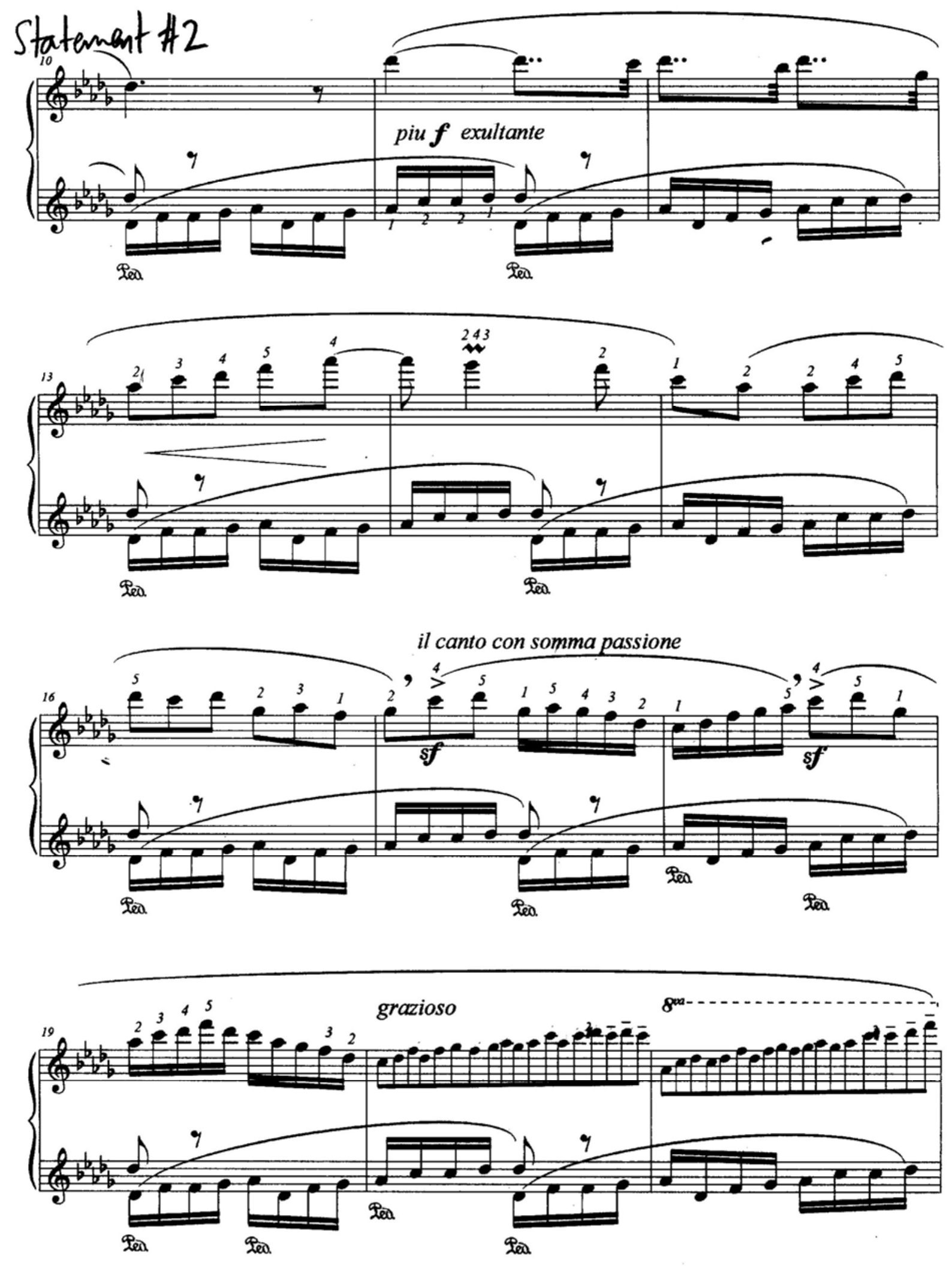

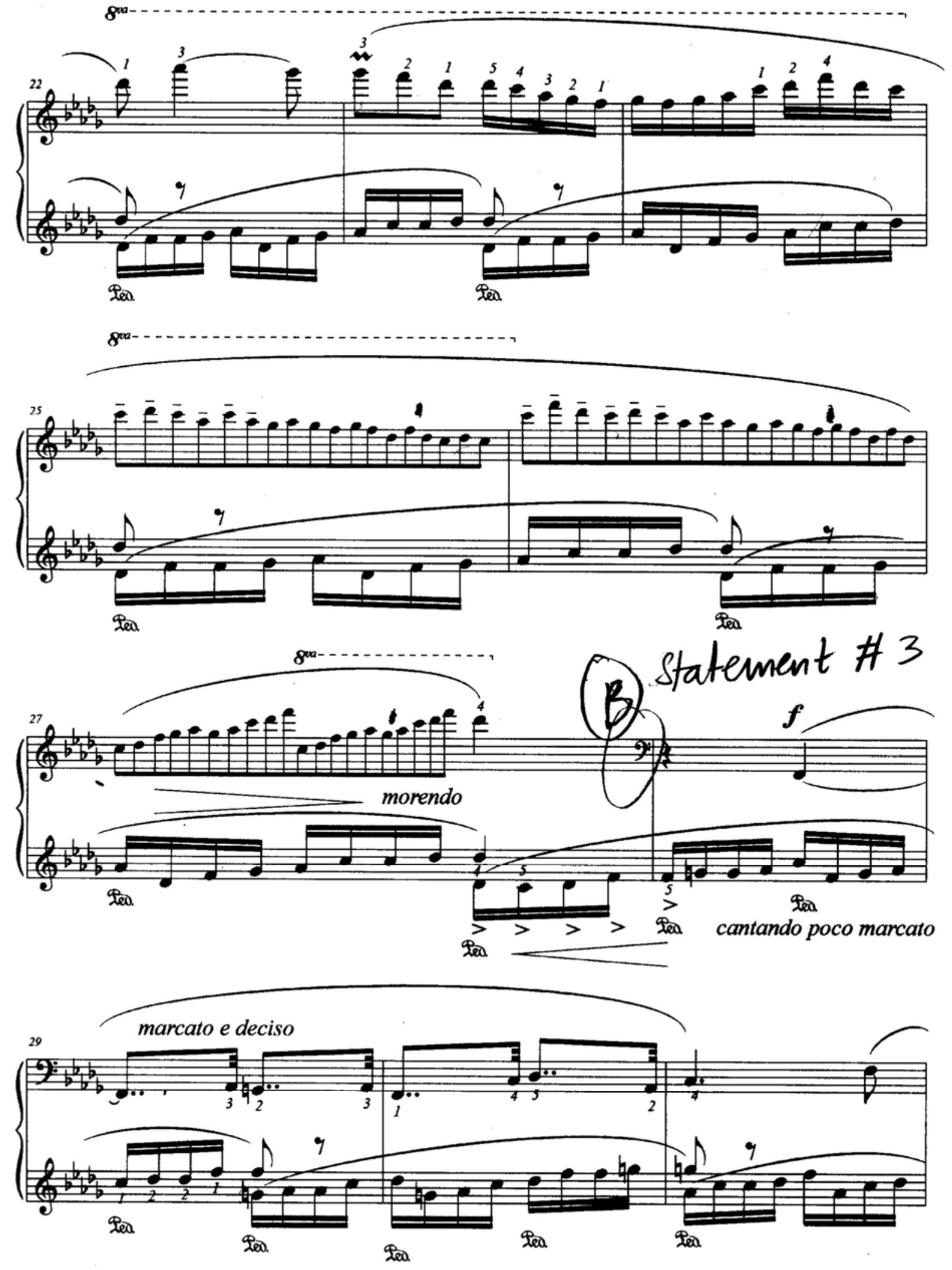
4
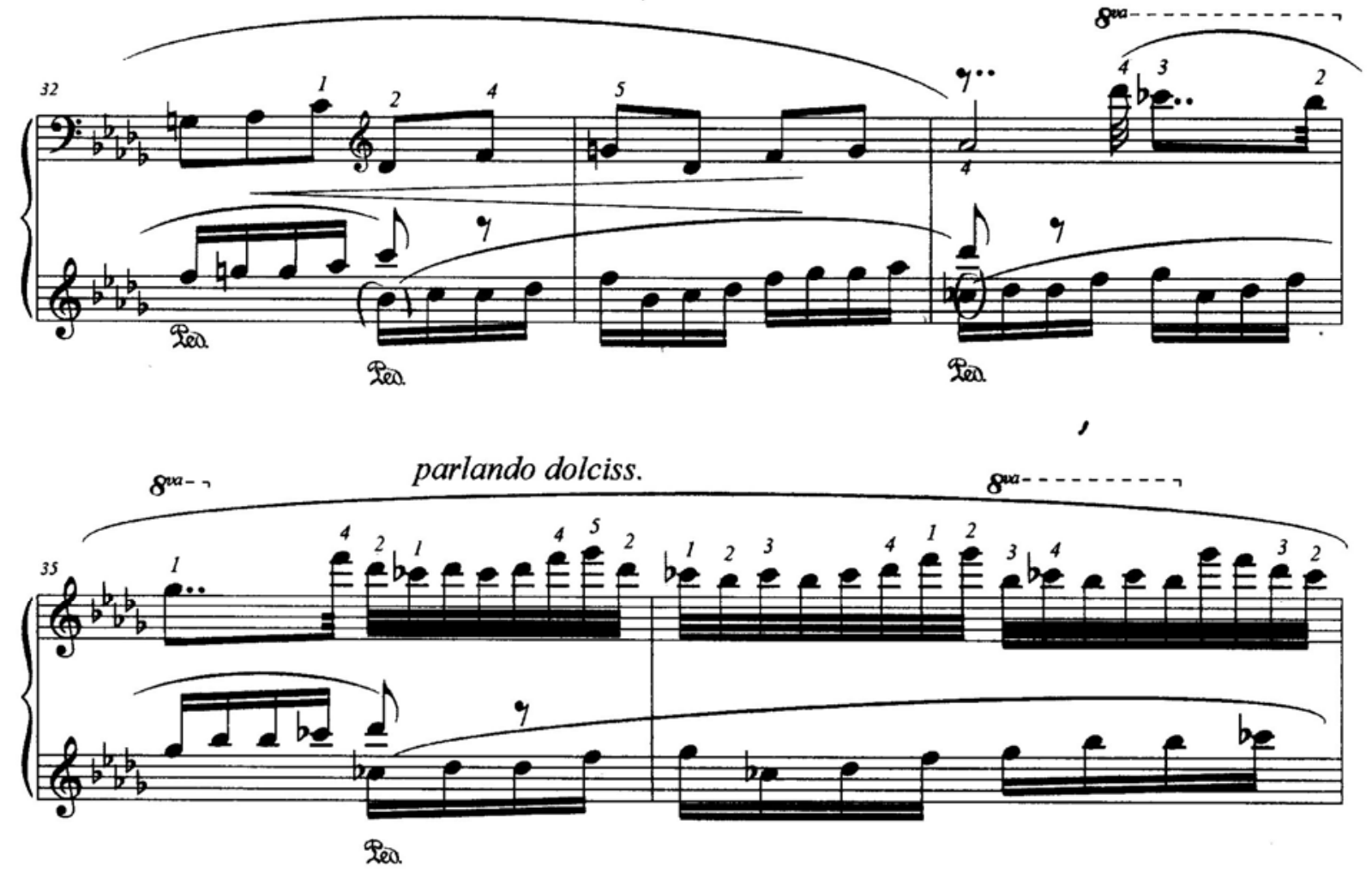

poco a poco piu animato

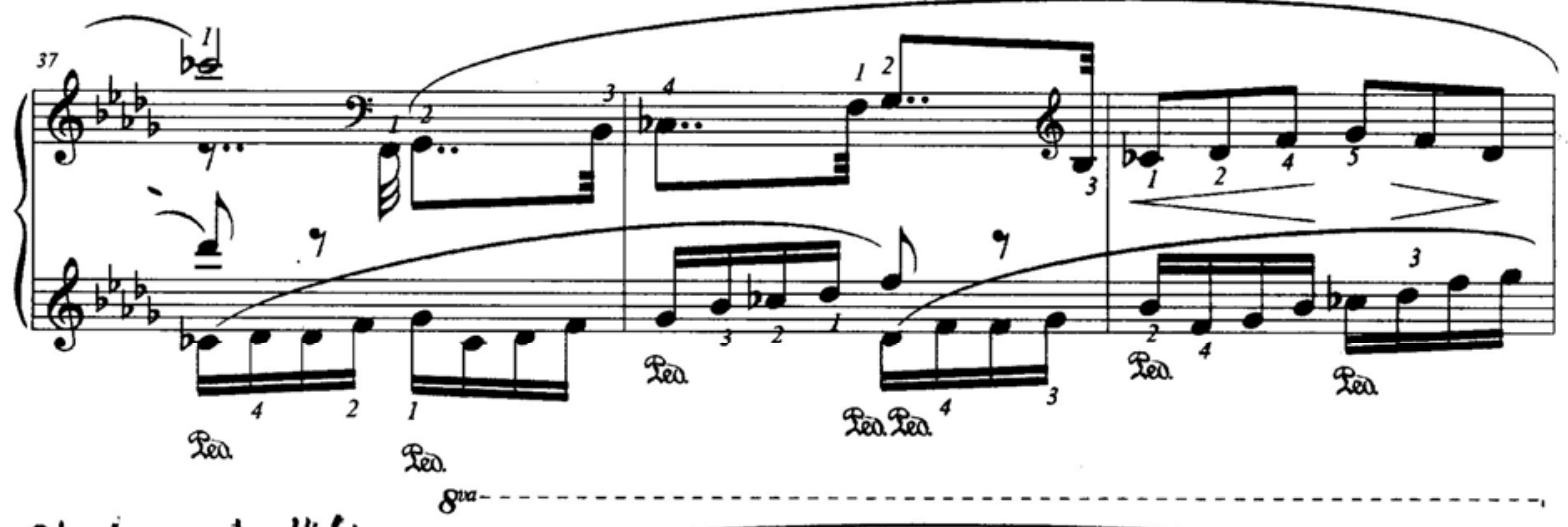

Statement $4: 42$ dolcissimo scherzoso

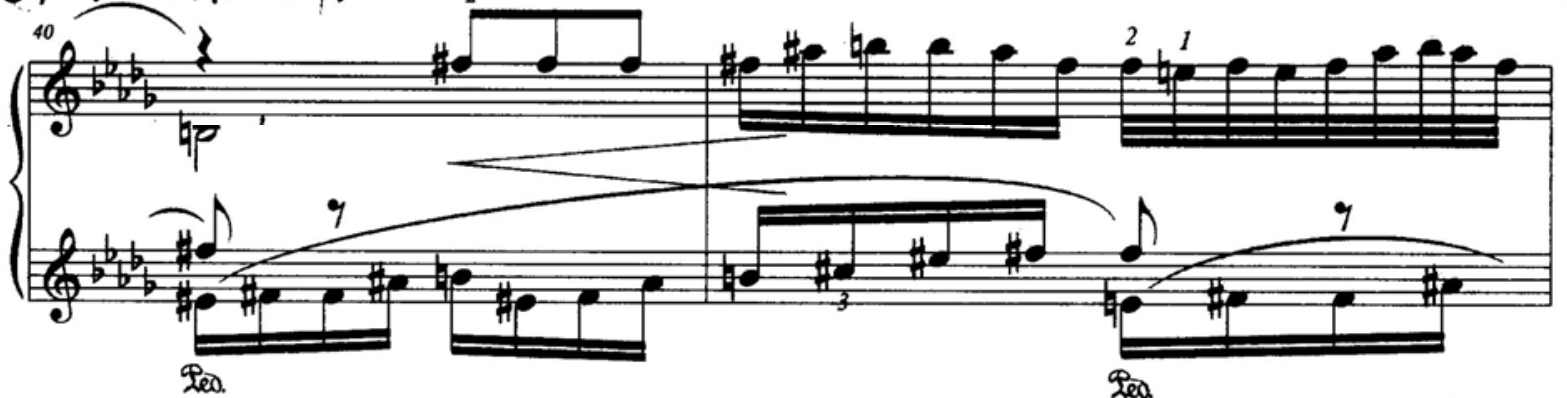



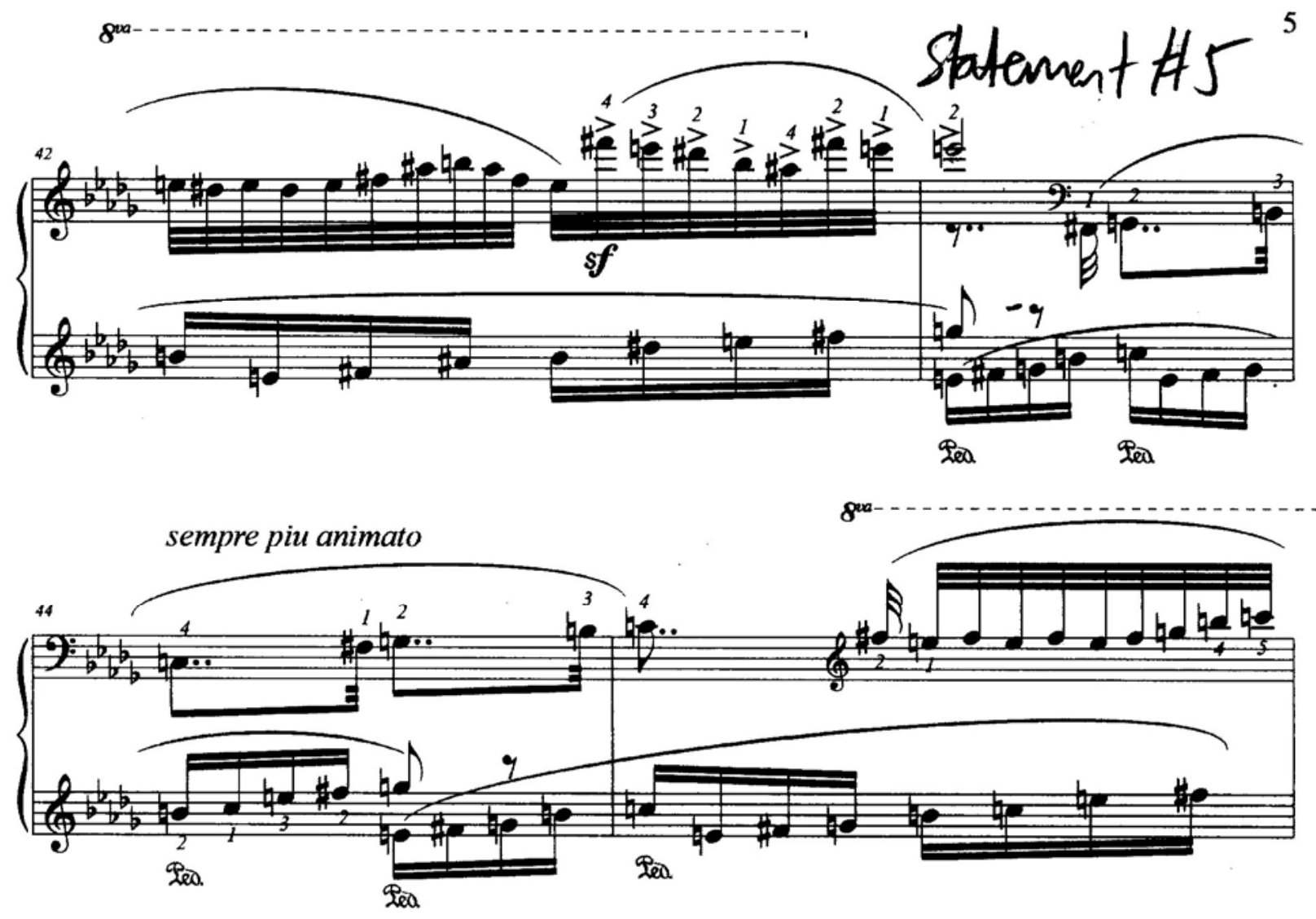

Statement His
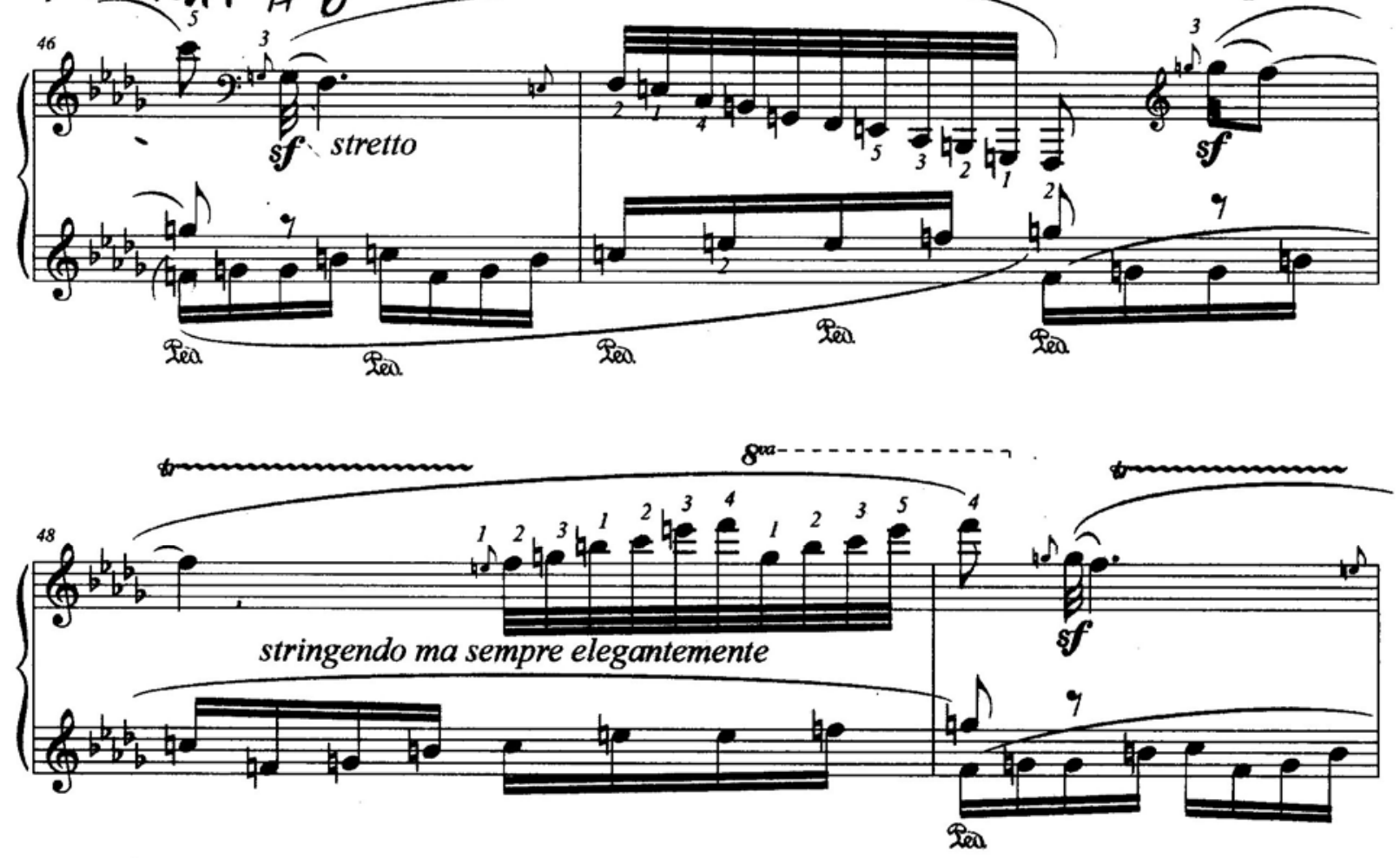

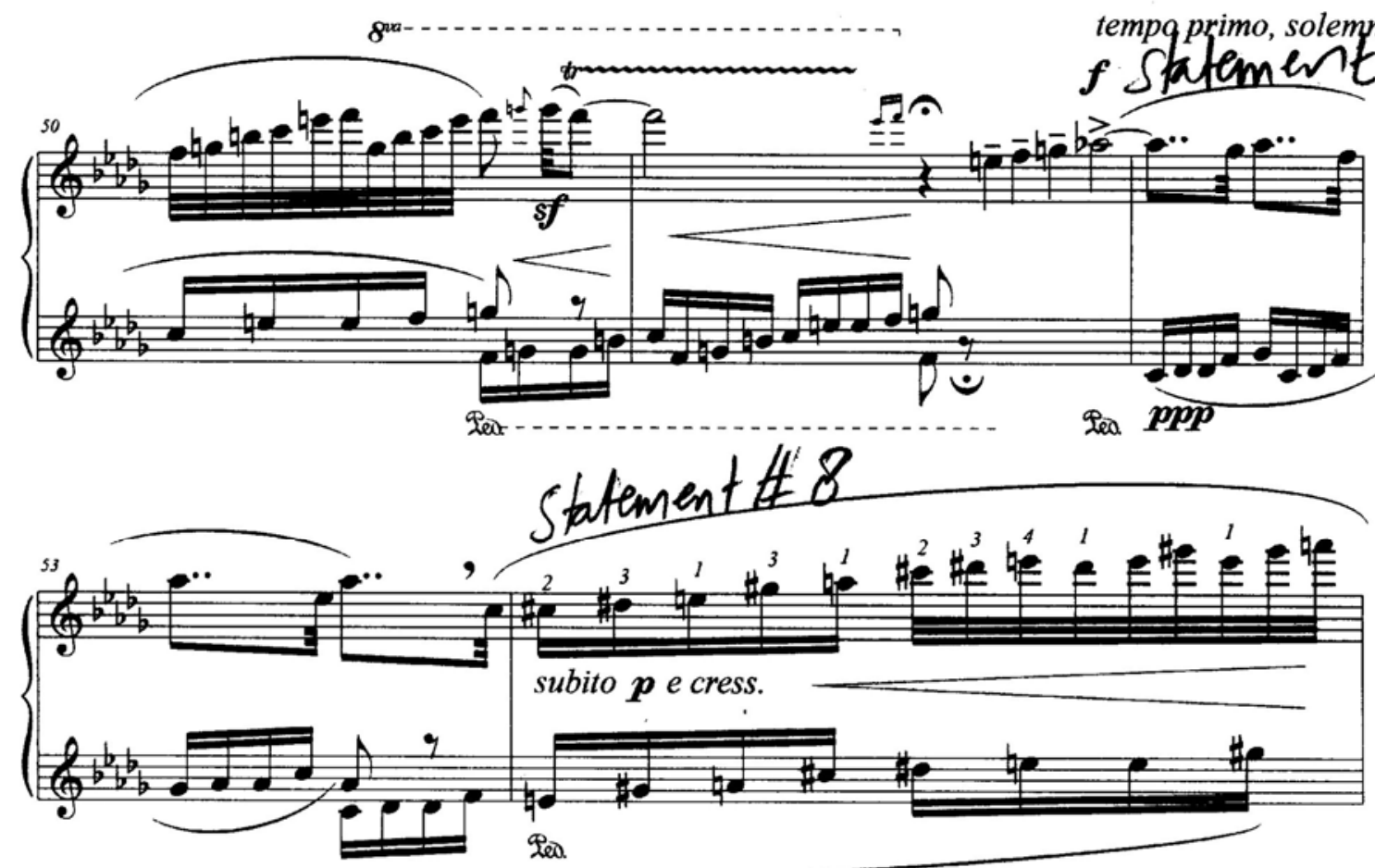

Dea
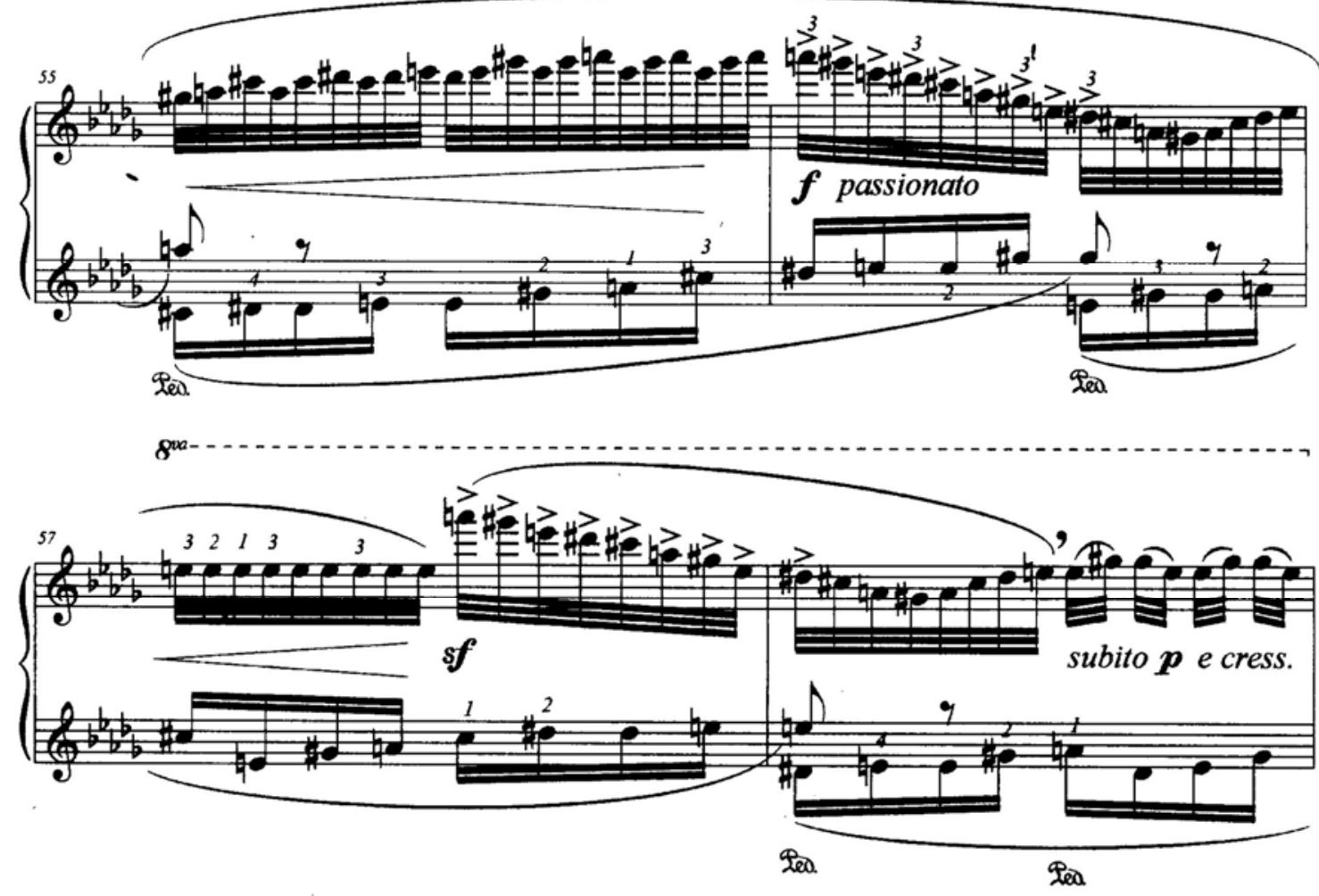


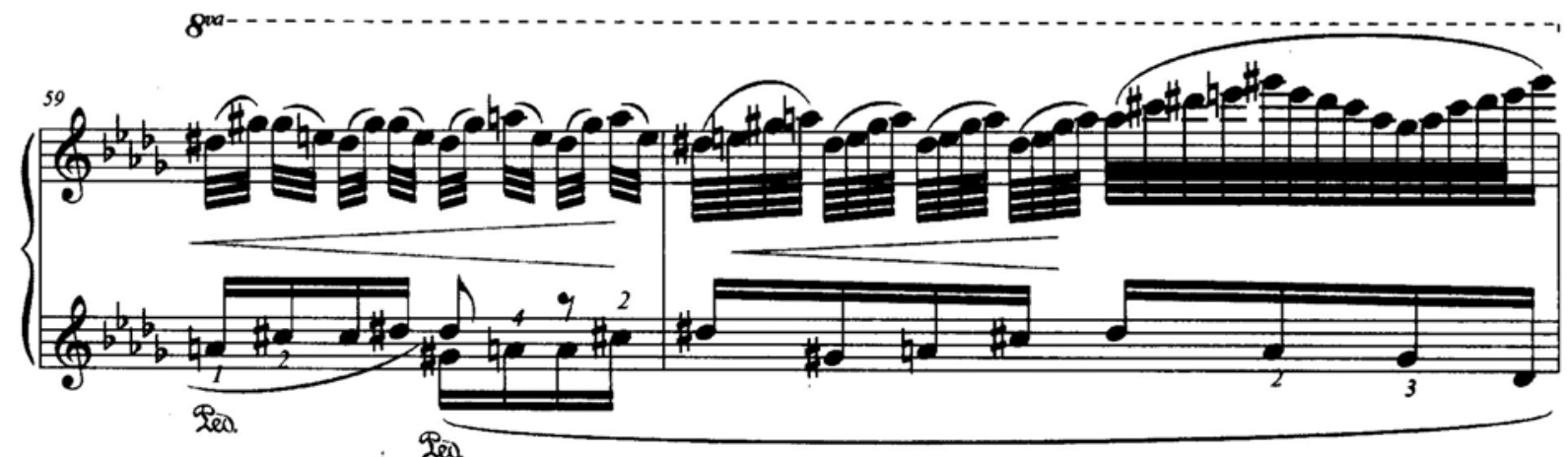

Statement if 9
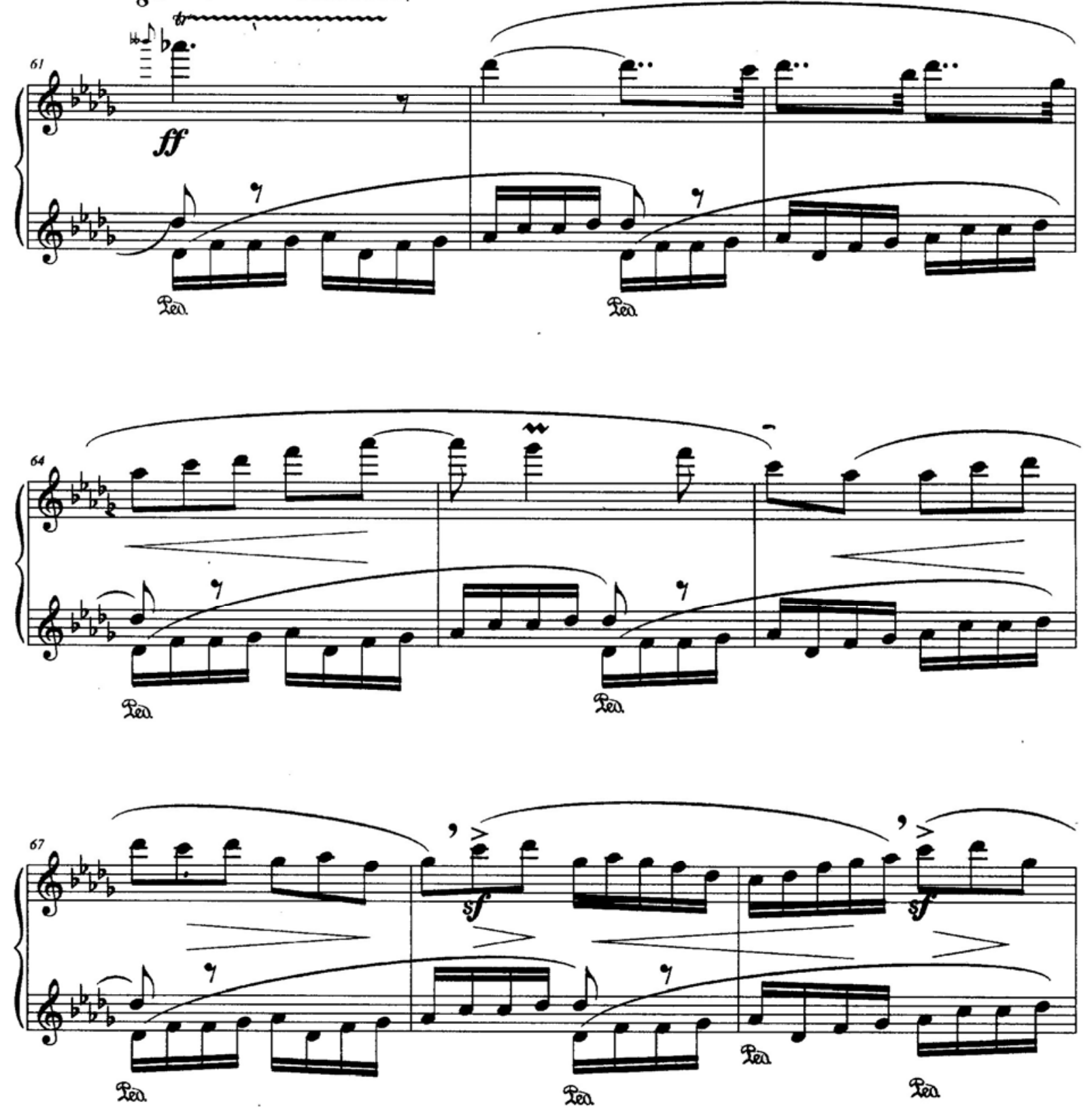

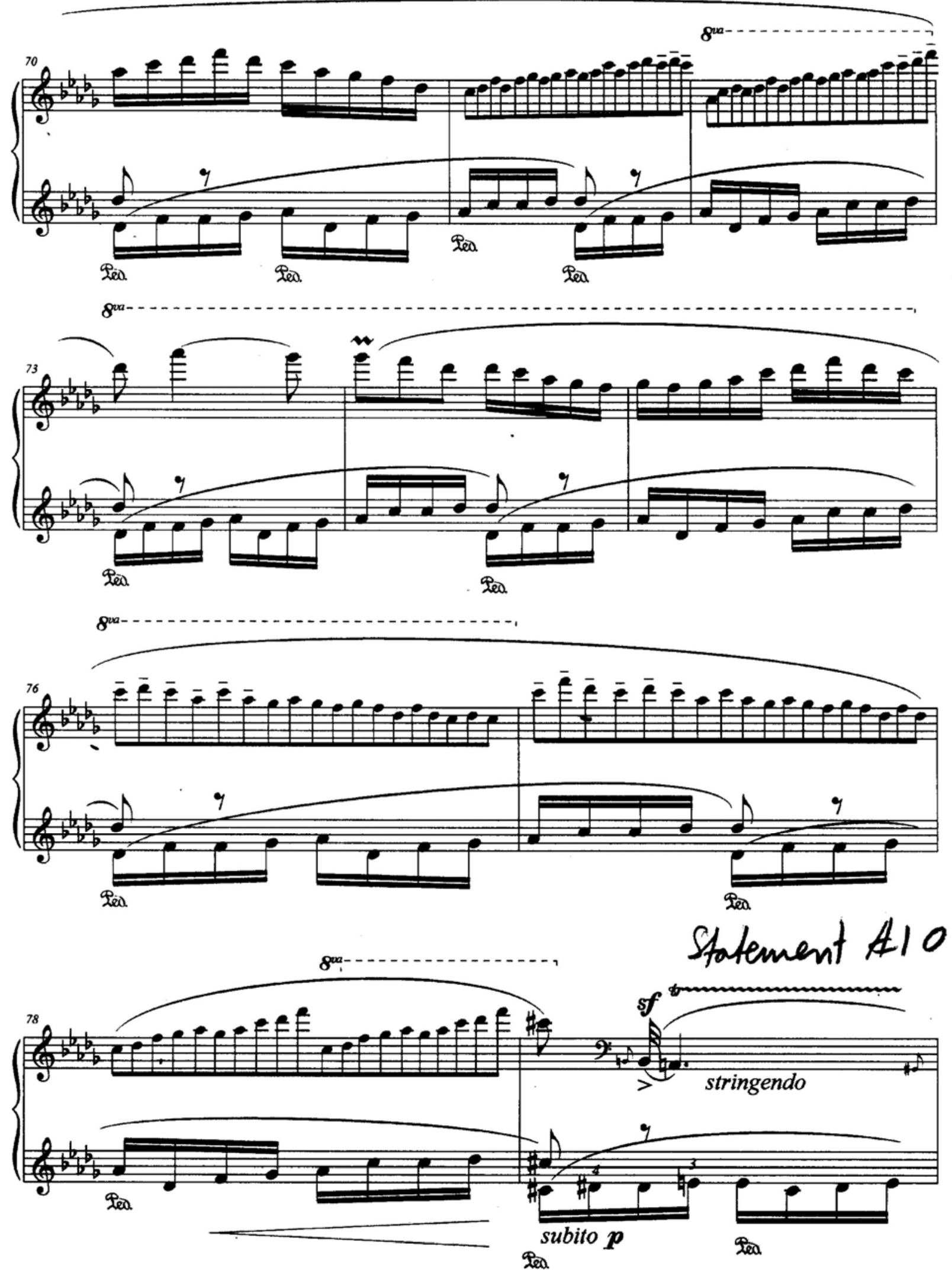

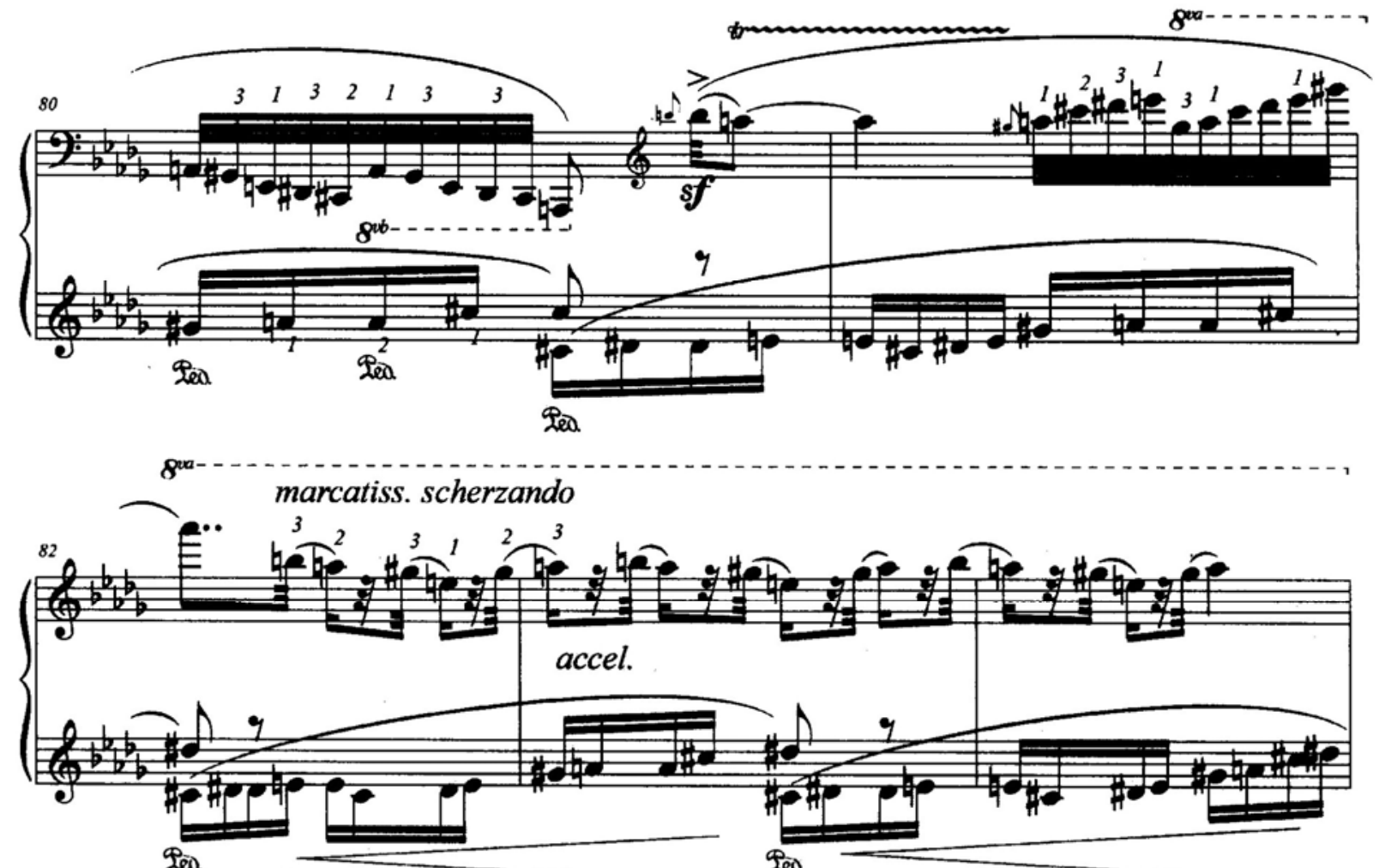

Stotment \#I!
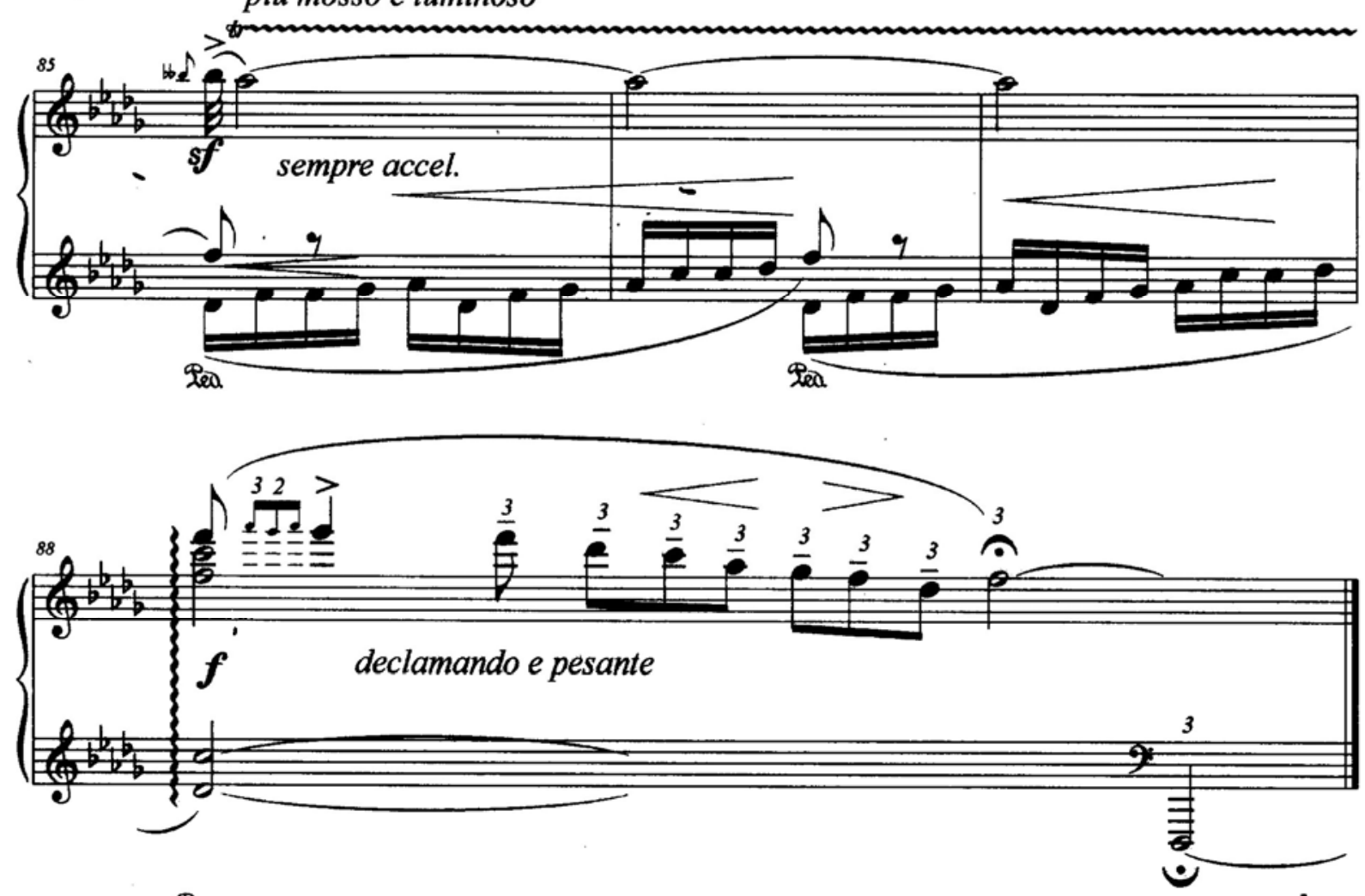

Ded $\ldots$ 


\section{APPENDIX F}

\section{Levi Gunardi’s Happy Birthday}

\section{Happy Birthday}

Introduction

Dedicated to M1rs. Iravati M. Sudiarso

Levi Gunardi

Scptember 28. 1995
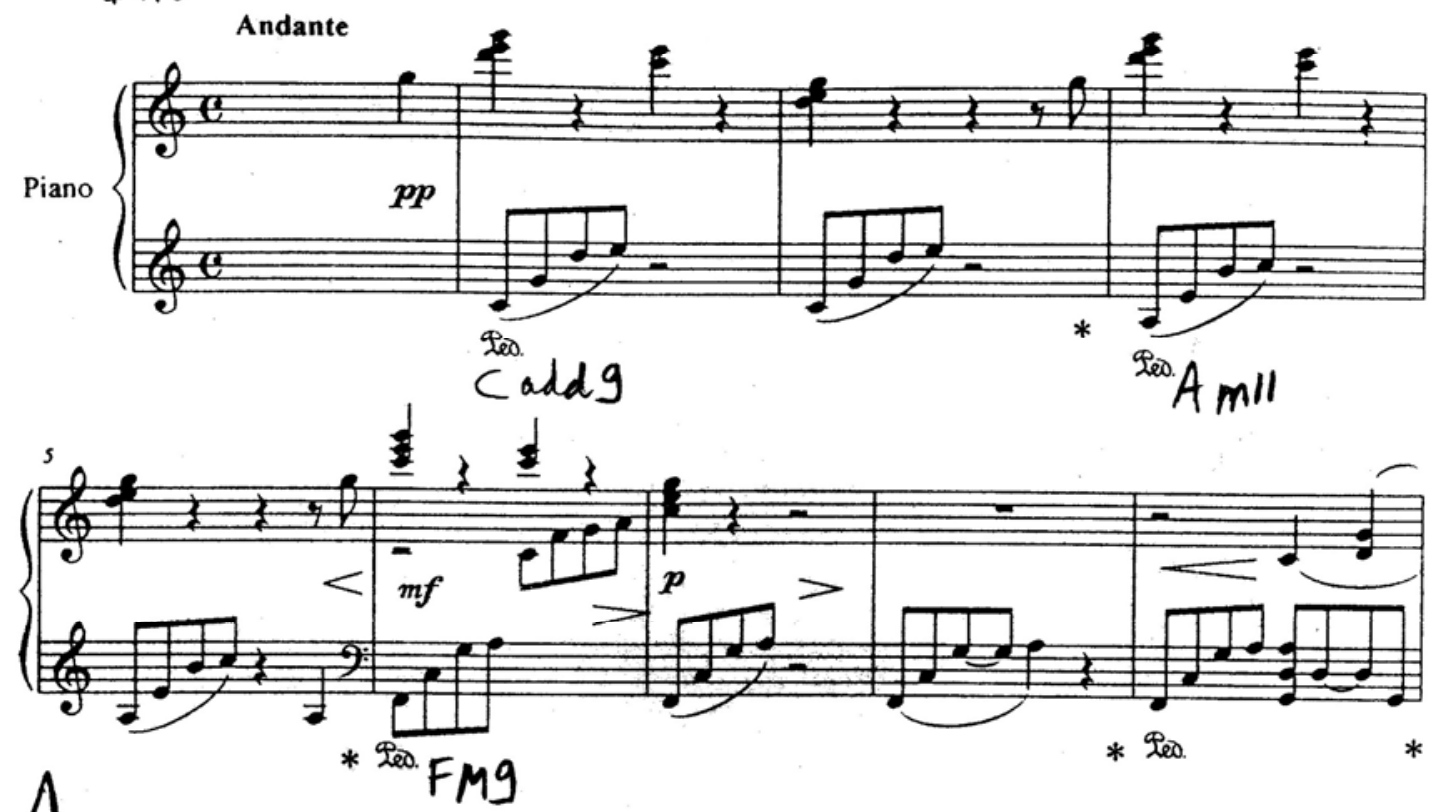

A

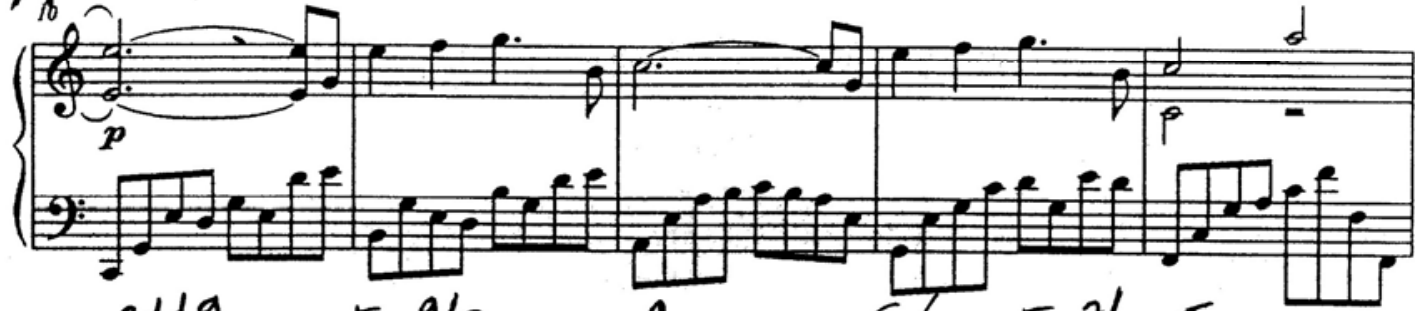

$C^{\text {add } 9} \mathrm{Em}^{9} / B \quad A_{m g} \quad C_{G} E_{m}{ }^{7} / D$ Faddg

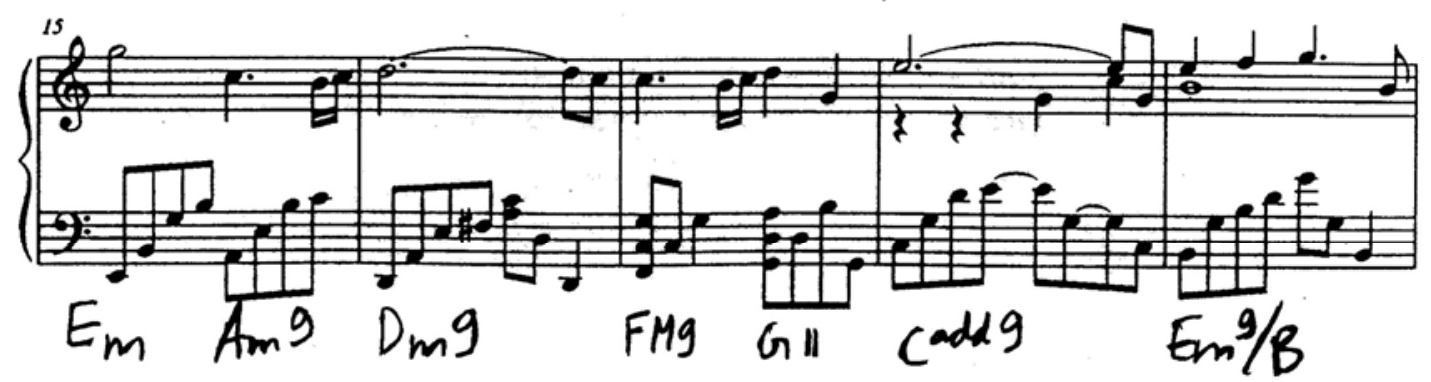

Copyright O 2006, Levi Gunardi 

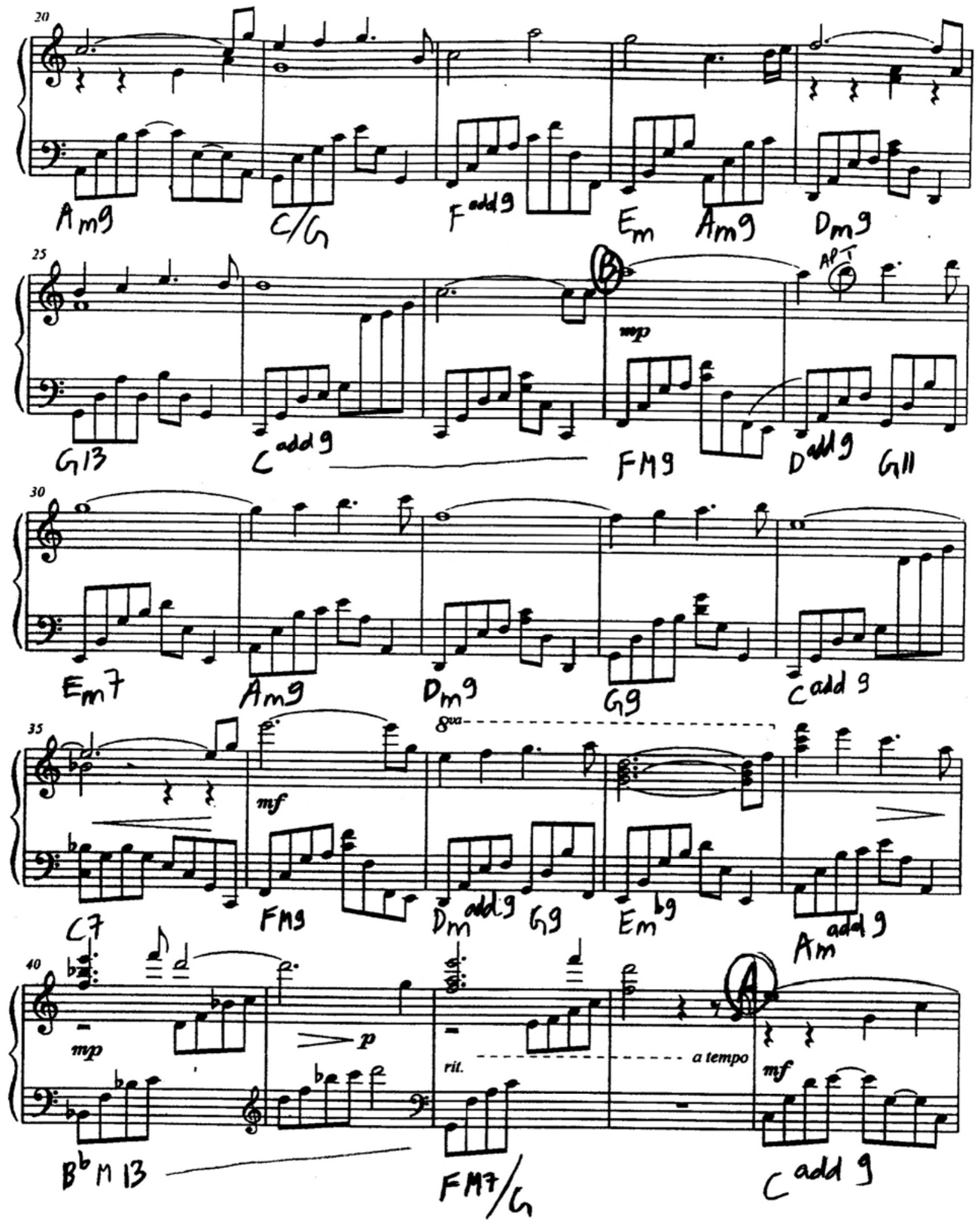

Copyright 0 2006, Levi Gunardi 

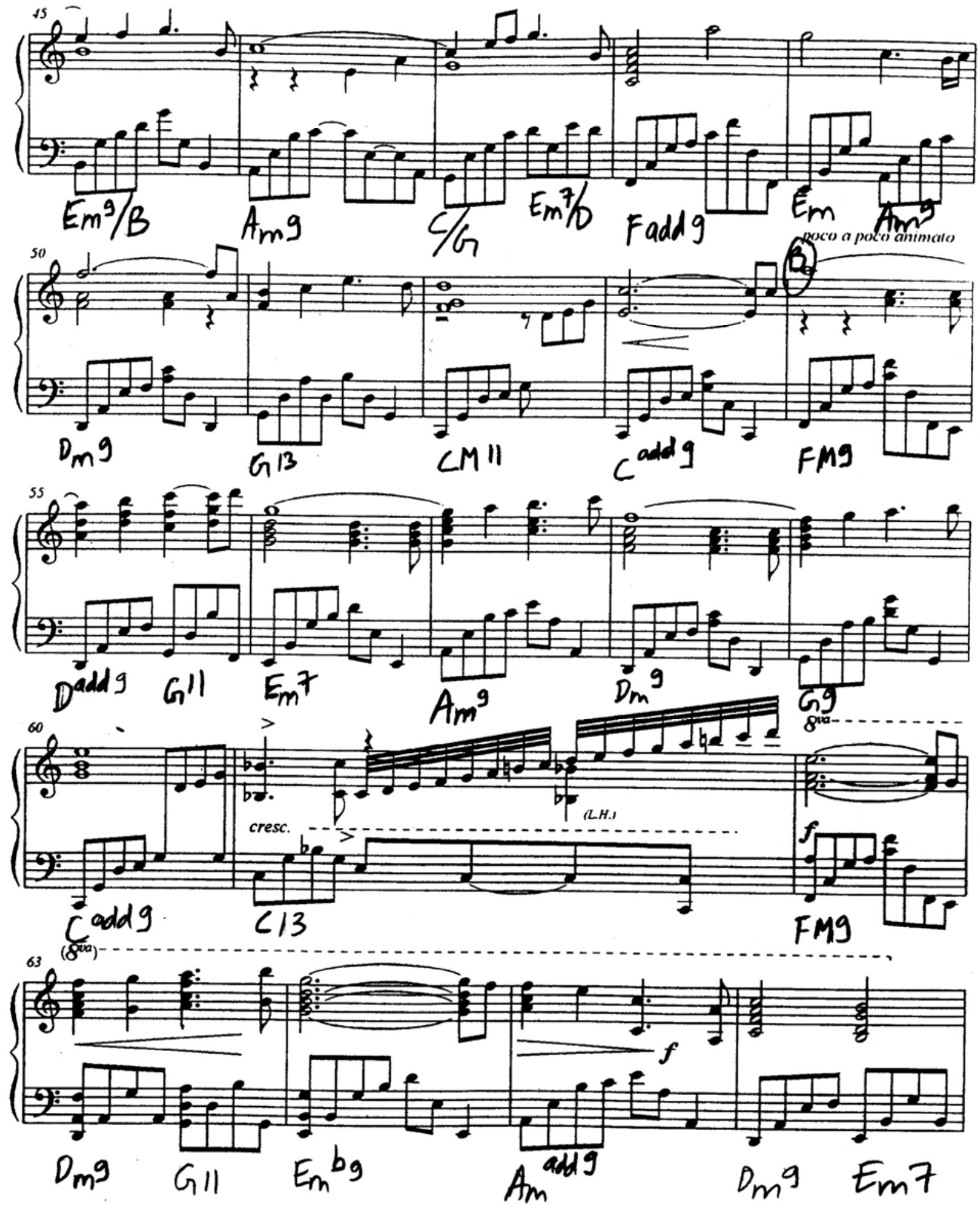

Copyright O 2006, Levi Gunardi 

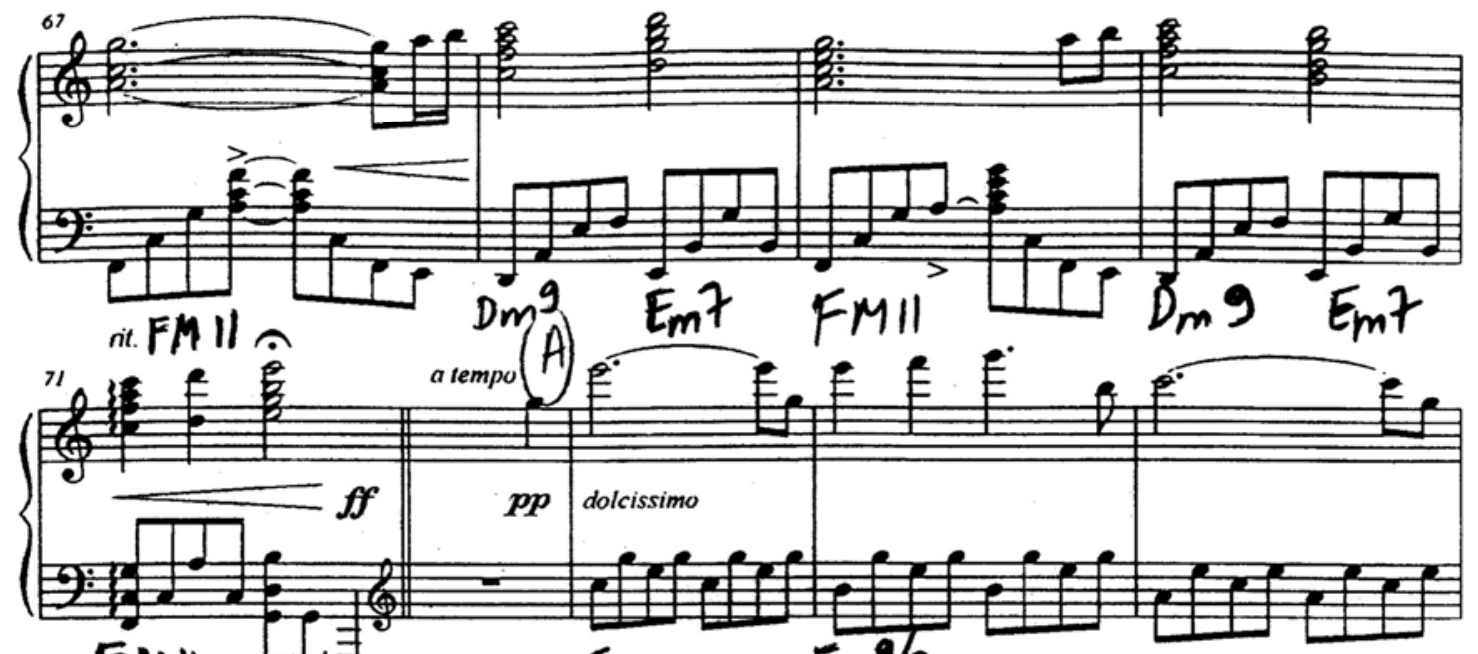

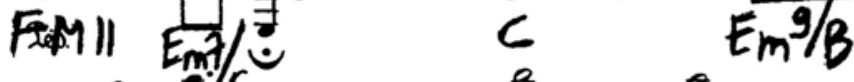
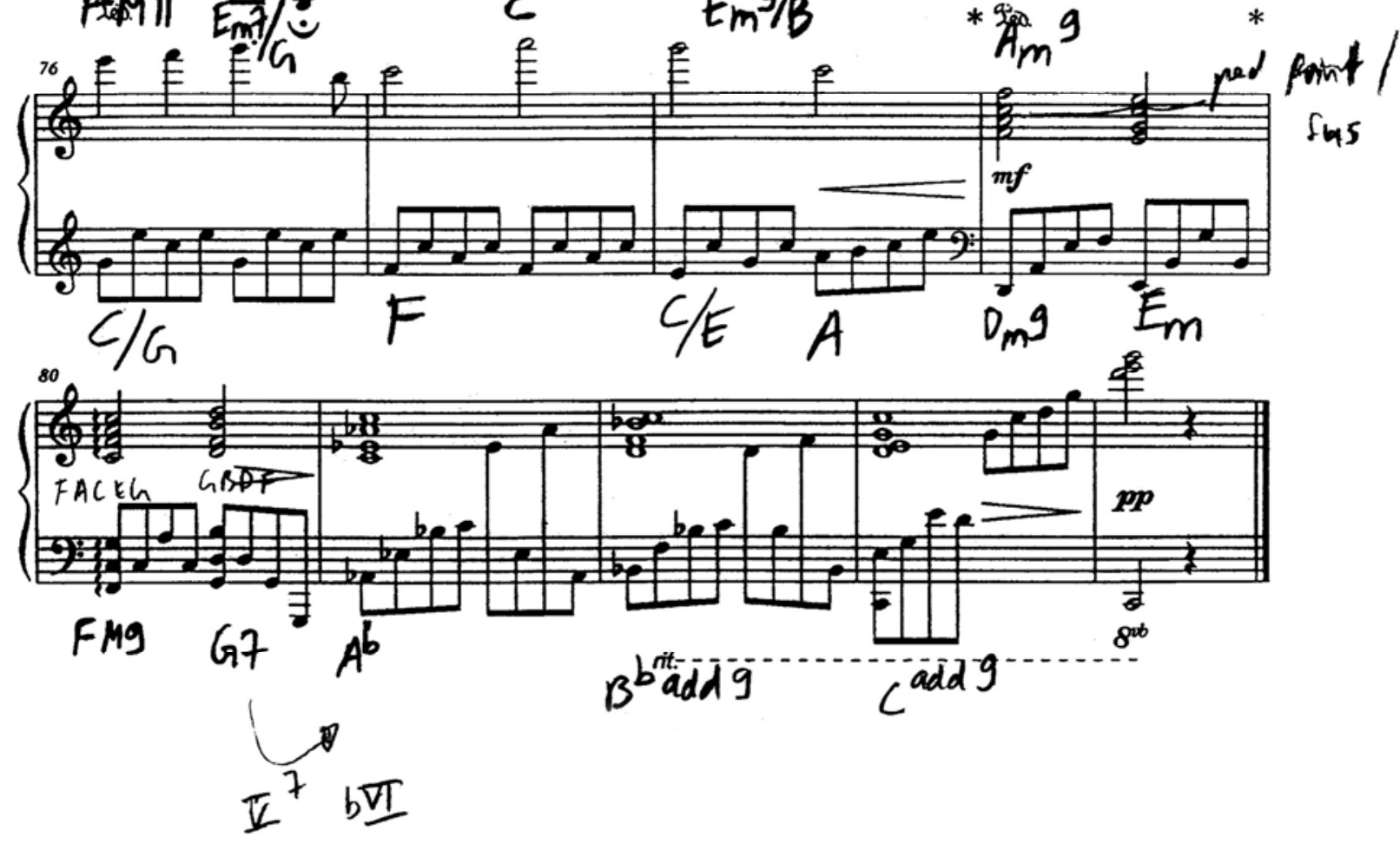

Ceprialn O 2006, Levi Gunardi 